Portland State University

PDXScholar

1987

\title{
El Sindicato de las Costureras 19 de Septiembre : the impact of the 1985 Mexico City earthquake on social process
}

Margaret McCrea

Portland State University

Follow this and additional works at: https://pdxscholar.library.pdx.edu/open_access_etds

Part of the Geography Commons, Latin American History Commons, and the Social History Commons Let us know how access to this document benefits you.

\section{Recommended Citation}

McCrea, Margaret, "El Sindicato de las Costureras 19 de Septiembre : the impact of the 1985 Mexico City earthquake on social process" (1987). Dissertations and Theses. Paper 2885.

https://doi.org/10.15760/etd.2879

This Thesis is brought to you for free and open access. It has been accepted for inclusion in Dissertations and Theses by an authorized administrator of PDXScholar. Please contact us if we can make this document more accessible: pdxscholar@pdx.edu. 
AN ABSTRACT OF THE THESIS OF Margaret MCCrea for the Master of Arts in Geography presented July 17, 1987.

Title: El Sindicato de las Costureras 19 de septiembre: The Impact of the 1985 Mexico City Earthquake on Social Process.

APPROVED BY MEMBERS OF THE THESIS COMMITTEE:

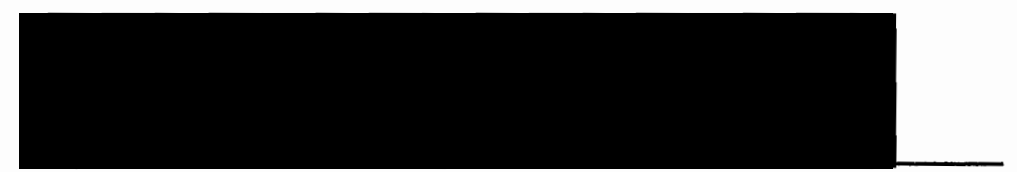

$$
\text { Martha Works, Chair }
$$

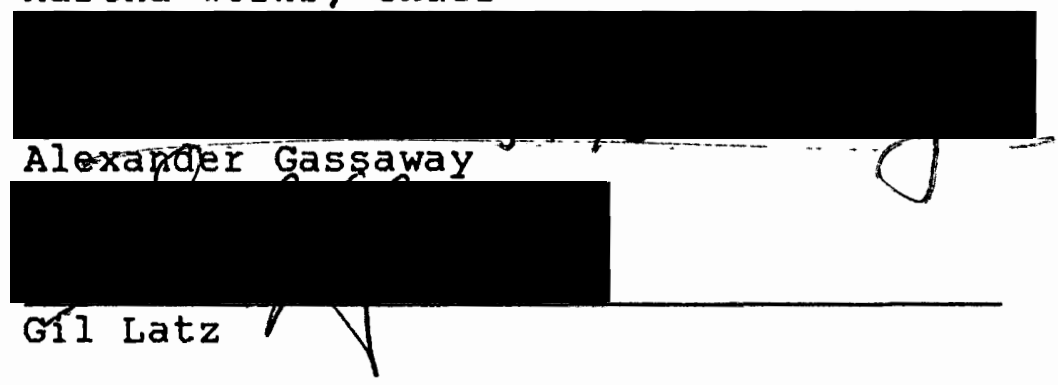

The issue of the impact of natural disasters on society is an important question in geographic research. Geography has traditionally taken a sociological viewpoint on this issue, but recent research has questioned some of the basic assumptions of the hazards literature, and has suggested that a much broader understanding of social process is necessary in order to analyze the impact of a natural disaster on a particular social system. This approach sees society as being in a constant state of "structuration," i.e., members of a social order build on the physical and 
cultural givens of the social system into which they were born while at the same time they transform them. The proponents of structuration theory, however, have done lillle empirical research of particular events. This paper suggests that the 1985 earthquake in Mexico City and the social conflict it generated, in the form of a labor conflict between the costureras (seamstresses) of the garment district, the government and the factory owners, offers an excellent opportunity to analyze social process in relation to physical structure. In this setting, the impact of a natural disaster is very complex, because of the complex relationships of those who are its victims.

The paper traces out the relationships between three sets of actors--workers, factory owners, and government-before, during and after the 1985 Mexico City earthquake, and places those relationships in the broader context of Mexico's political and economic development, as well as the spatial structure of Mexico city and the garment district. The paper concludes that although victims respond to the crisis by attempting to restore and repair previous social and physical conditions, as social theoxy predicts, disasters have different effects on different classes of people, who respond according to their needs, vulnerabilities, perceptions, values, and their socially prescribed powers. Where there is no consensus among social 
classes as to what the normal or desirable social system is or ought to be, conflict between sectors of the population, which was embedded in the social and spatial system, takes a new form as a result of new conditions caused by the disaster.

The research methodology was mostly archival, relying on contemporary newspaper accounts of the events, interviews with the participants, and publications by the union and researchers who collected information for the union. Recently published scholarly works were relied on for Mexico's history and political and economic development, and a broad array of works on social theory, from the fields of geography and other social disciplines, were drawn from for analysis. The paper concludes by suggesting that further research needs to be done on the creation of "opportunity surfaces" through social structuration, the relationship between spatial change and social change, and group emergence as a result of natural disaster. 
EL SINDICATO DE LAS COSTURERAS 19 DE SEPTIEMBRE:

The Impact of the 1985 Mexico City Earthquake on Social Process

by

MARGARET MCCREA

A thesis submitted in partial fulfiliment of the requirements for the degree of

\author{
MASTER OF ARTS \\ in \\ GEOGRAPHY
}

Portland state University 
TO THE OFFICE OF GRADUATE STUDIES AND RESEARCH:

The members of the Committee approve the thesis of Margaret McCrea presented July 17, 1987 .

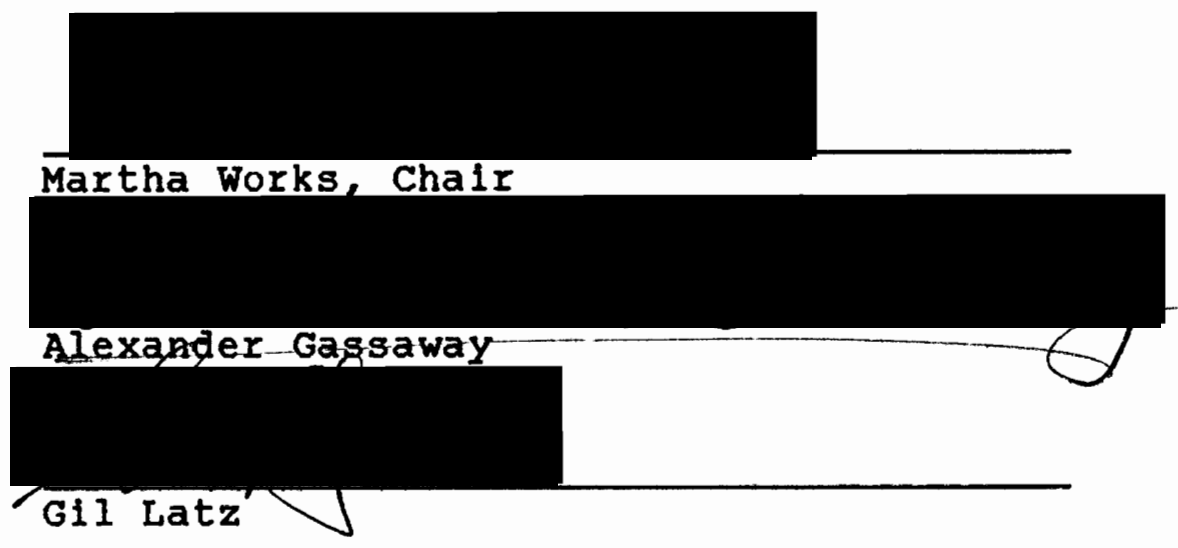

APPROVED:

Thomas My Poulsen, Chair, Department of Geography

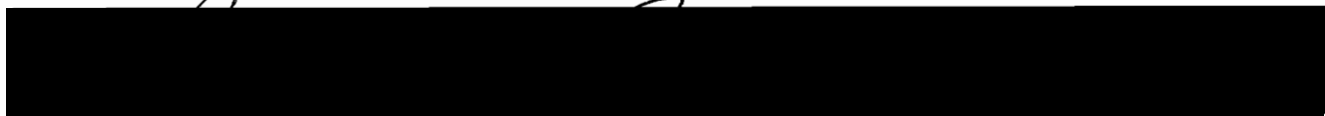

Bernard Ross, Vice Provost for Graduate studies 


\section{DEDICATION}

This paper is offered to sara Lovera, reporter and writer for the dally newspaper La Jornada of Mexico City, Mexico. Her consistent and persevering reporting on the costureras and their labor struggle, as well as on the nature of the garment industry in Mexico, the high quality of her writing and the breadth of her reporting deserve the highest journalism recognition her country and her profession have to offer.

In addition, this paper is offered to the women of Mujer a Mujer, Mexico City, Mexico. Their dedication and hard work towards the goal of international exchanges between women of North America and women of Mexico made it possible for me, as well as many other U.S. women, to meet our slsters in Mexico and to know of their lives. Work such as theirs is making it possible for women all over the world to weave the web of peace and development. 


\section{ACKNOWLEDGMENTS}

Many people worked with me on this paper, and their energy and advice has been appreclated greatly. Martha Works put in many hours reading and editing this work, and her insights and support have been most welcome. Leslie Anderson kindly did the graphics. Many people in Mexico, too numerous to name, offered their time and information while I was doing the research. Friends gave me time and support, including access to their computers and their computer knowledge. Last but certainly not least, my mother, Ruth McCrea Packard, made it possible for me to obtain a word processor, without which this work would not have been finished. It is my hope that this work is worthy of the faith and support that have been so generously given to me. 
TABLE OF CONTENTS

PAGE

DEDICATION..........................

ACKNOWLEDGMENTS ........................ iv

LIST OF TABLES ....................... vi i

LIST OF FIGURES ......................... IX

CHAPTER

I INTRODUCTION....................... 1

statement of the Problem.............. 3

Natural Disaster in Geographic Literature.... 4

Social systems in Geographic Literature..... 11

structure of This Paper............. 17

Methodology..................... 19

I MEXICO CITY AND ITS EARTHQUAKES.......... 21

Economic Growth and the Growth of the C1ty.. 29

The Garment District of Mexico City....... 35

II T THE WEAKENING OF A POLITICAL BARGAIN........49

Revolutionary Roots............... 50

The state as protector of Labor.........53

Labor Unions in the Garment District...... 57

Government and costureras in Confl1ct..... 59 
IV THE COSTURERAS AND THE CRISIS..........6 63

The Economic "Miracle"..............64

From Agriculture to Industry

Land Reform and the Working Poor

The Working Poor and the "Miracle"

Development of the Crisis

The Position of the costureras in the

Garment Distr1ct................ 73

The Costureras as a Special Case

of the Working poor

Implied and overt Conflict in the Factories

The Costureras Respond to the Cr1s1s......79

$\mathrm{v}$ CONFLICT IN THE GARMENT INDUSTRY......... 87

The Garment Industry in Crisis........ 88

The Nation's Capitalists.............90

state-Capital Relatlons..............93

The outbreak of Conflict.............97

vi conchusion............................ 102

Opportunity surface and Exploitation...... 103

spatial Change and soclal Change........ 105

Peasant Values in a Proletarian setting.... 107

Class struggle and the Control of space... 109

Long Term social Change............. 112

ENDNOTES....................................... 116

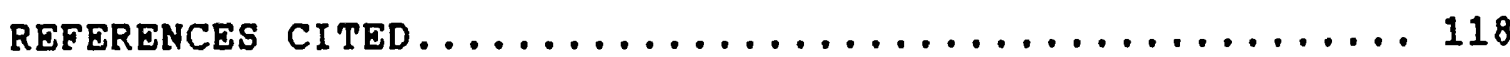

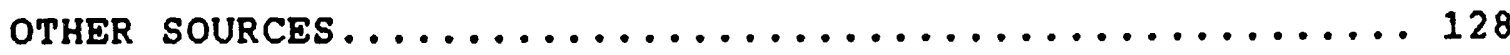


APPENDIX A: Locations and Characteristics

$$
\text { of the Conflicts................. } 134
$$

APPENDIX B: Chronology of the Formation of the Union.... 142 


\section{LIST OF TABLES}

TABLE

PAGE

I Population within the Federal District and

Municipalities of the state of Mexico....... 31

I Sites of Labor Conflict After the Earthquake,

By Location and Name of Business......... 37

I I Development of the Economy, $1940-1980 \ldots \ldots \ldots \ldots 6$ 


\section{LIST OF FIGURES}

F I GURE

PAGE

1. Mexico City, the Eplcenter of the Earthquake, the Middle American Trench, states in which

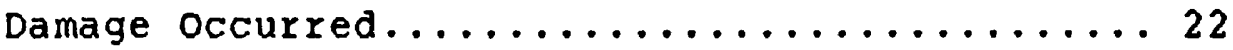

2. Mexico city Urban Area, $1960,1970,1980 \ldots \ldots \ldots . .30$

3. Garment District of Central Mexico City......... 36

4. Garment Factory Above Retall stores........... 39

5. Garment Factory Above Pharmacy.............. 39

6. Small Garment Factory.................. 40

7. Several Mid-sized Factorles in one Bullding......4 40

8. Modern Garment Factory..................4 41

9. Clothing Store Advertising Retall and

Wholesale sales.....................41

10. Independent Contractors Delivering Goods........ 42

11. Garment Factorles Above Clothing stores.........42

12. Union Headquarters, showing "Bullaing of

Tombs" in Background................46

13. Tents From the Encampment Used for Union

offices...................... 46

14. Union Organizers at Exposition of Union History.. 110 


\section{CHAPTER I}

\section{INTRODUCTION}

on september 19, 1985, at 7:19 a.m., an earthquake measuring 8.1 on the Richter scale rocked Mexico City. The shaking of the city lasted approximately two minutes. An estimated 500 to 1,000 bulldings came down, while up to 3,000 others were damaged. Figures for the death toll range from 4,000 by official government figures to 20,000 by newspaper accounts. Between 100,000 and 250,000 people were left homeless and 30,000 were injured (U.S. AID 1986).

In the garment district of central Mexico city, in the region known as San Antonlo Abad and an area to its north called simply el centro (the Center), as many as 1600 seamstresses, or costureras, were killed when the buildings in which they were working, originally designed for housing and small shops, collapsed under the welght of heavy machinery during the earthquake. over the next several days and weeks, rescue efforts were co-ordinated and carried out by family and friends of the costureras, as there was no apparent government agency available to do this work. Gradually, the "sweatshop" conditions of the factorles in which the women had been working came to public attention. Further, when the owners of the shops began to rescue their 
machinery, materials and strongboxes with privately hired men and equipment, while the Army prevented the families of costureras from rescuing the workers, open conflict broke out in the district. Costureras and their supporters selzed goods as they were brought out of the factorles, they sat down in front of heavy machinery rented by owners to remove equipment, and they confronted owners of the shops for rescue and back pay.

Word of the events spread quickly, mostly through the work of feminist journalists who published dally accounts of the conflicts, and immediately the costureras became a cause celebre. Help came from all over the city: women's groups organized food and daycare for the costureras, who were sleeping on the streets and literally sitting on seized equipment; lawyers came to offer legal assistance; union organizers and radical leftists came to help with the political work. Within two weeks, the costureras decided to form a single union out of the several groups that had sprung up all over the district. The next two weeks were a time of intense activity, as the scale of the organizing and the demands went up. Foremost among the demands was the rescue of women still inside the bulldings; later, the workers demanded recovery of bodies. Calls were made for registration of clandestine factorles, for inspection of bulldings for safety before workers were required to resume 
work in them, for minimum wages, reparations and severance pay, retroactive soclal security, backpay, and daycare and transportation costs. Most of all, the women demanded an independent union, one that would operate outside all of Mexico's existing federally administered labor unions.

The government was caught short by the revelations of the conditions in these factorles, and of the repressive acts of the soldiers, and was forced to send representatives to the district to promise studies and better conditions. That did not satisfy the demands. On october 19, 1985, just one month after the earthquake, the costureras marched en masse to the Presidentlal palace and met with the President of Mexico, demanding their own, independent union. On October 20, 1985, the secretary of Labor personally signed the articles granting official recognition to the union, El Sindicato de las Costureras 19 de septlembre (19th of September Union of Garment Workers), the first such independent union to be recognized in Mexico in fifteen years.

\section{STATEMENT OF THE PROBLEM}

This paper proposes to undertake an analysis of these events in light of geographic and social science literature concerning the impact of natural disasters on social systems. Specifically, this paper will focus on the role of 
the earthquake in the processes of social change. Since a militant labor union is not an expected outcome of an earthquake, the question is both why and how the Union 1 emerged from the crisis of the earthquake. It is assumed that the earthquake either created conflicts, or exacerbated or changed pre-existing conflicts, and it did so by some identiflable means. The purpose of this paper is to identify those conflicts, or potential conflicts, and to examine the role of the earthquake in relation to those conflicts. Previous geographic literature sheds some light on this question, but it also points up areas needing further research.

\section{NATURAL DISASTER IN GEOGRAPHIC LITERATURE}

Natural hazards ${ }^{2}$ research began with Gilbert white's research in the mid-1940's on the human occupancy of floodprone areas. Work by white, and later by white and two of his students, Ian Burton and Robert Kates, was consclously based on human ecology (Burton 1974; Kates 1971). That is, human soclety is assumed to be in a state of dynamic equilibrium with natural systems, and thus must make periodic adjustments in response to the actions of natural systems. Those responses are based upon the rational decision-making of individuals and of governmental policymakers, based on their perceptions, knowledge and 
experiences. The approach focuses on the technological and scientifically informed way that individuals and managers can predict, mitigate or respond to various kinds of natural disasters. Burton, Kates and white have had such a strong influence on geographic research of natural hazards and disasters that as late as 1974, James K. Mitchell organized an overview of the literature of natural hazards research along the above-described Iines (Mitchell 1974). The overview covers human occupancy of hazard areas, varlations in types of events, individual perceptions of hazards, policy-makers' perceptions of hazards, policy-makers' responses to hazards, and listed under "effects of natural hazards" costs and losses, beneflts, and intanglbles. clearly such an approach is not useful in examining the events of the earthquake in Mexico city and the labor union that emerged from it. These works contain no sense of social organization outside of the lone individual, or many lone individuals on the one hand, and the non-personal machinery of their governments on the other. The emphasis on "management" assumes an objective and rational bureaucratic system and an undifferentlated, passive population, assumptions which overlook government's potential for its own political agenda. Omitted are any sense of class, caste, community, tribe, clan, ethnicity, religion, and gender, as well as the expression of power and 
conflicts between such social groups, including those groups which provide the "managers" in times of disaster. There are hints of this gap in the literature. Mitchell referred to "a lack of detalled studies of collective adjustment decisions, especially at the local community leveln (Mitchell 1974: 331). Kates, in his analysis of the human impact of the Managua, Nicaragua earthquake of 1972, stated that too much emphasis had been placed on the physical events and not enough on the soclal consequences of the disasters. "Of some 40 earthquakes in the last 25 years for which detalled scientiflc and englneering reports are avallable, only four have been serlously studied and reported upon by social sclentists" (Kates 1973: 981). However, sociologists have written extensively on the impact of natural disasters on local communities, to the extent that this particular question has become somewhat of a specialty of sociology. ${ }^{3}$ Works by Baker (1962), Barton (1963, 1969), Dynes (1970), Form (1958), Milet1 (1975), Prince (1920), Quarantelli (1978), and Sorokin (1942) show that for a number of years, soclologists have done serious research on the impact of natural disasters on soclety. Much of this work has drawn on geographic literature, possibly because geographic literature includes research on the physical dynamics of the events themselves, which is lacking in the soclological research; the geographic 
literature, however, has not made use of the sociological research. For example, while the Mileti work entitled Human Systems in Extreme Environments: A Sociological Perspective

(1975) cites liberally from the individual and collective works of Burton, Kates and white, the classic work by Burton, Kates and white The Environment as Hazard (1978) does not cite Barton, Dynes, Quarentelli or any of the other sociological works cited above. Nevertheless, the same approach to natural disasters and their impact on soclal systems informs both the sociological and the geographic approaches: soclety is assumed to be in a state of equilibrium or normalcy, the disaster disrupts that equilibrium by creating an impact from outside the social system, and the response of the social system is to provide relief, restoration and reconstruction of the previous state of affairs as soon and as completely as possible. Sjoberg's statement that "quite soon after the disaster, actors strive to reinstate the disrupted patterns--to recover the state of normalcy or equilibrium" is a typical example of this human ecology approach (Sjoberg 1962: 369).

With the advent of the famine in the sahel region of Africa in the late 1960's and mid-1970's, a sudden and distinctive turn was taken in the analysis of natural disasters, their causes and consequences. Based on the work of French geographers (Copans 1983; Meillassoux 1974), as 
well as rethinking by the international rellef agencies such as the United Nations (Stephens 1979) and the Red Cross (Wijkman 1984), criticisms were raised that the traditional approach to disaster research falled to analyze the political, economic and social contexts in which disasters occurred. Speciflcally, such articles as o'keefe's "Taking the Naturalness out of Natural Disasters" (1976), Torry's "Hazards, Hazes and Holes" (1979a), and Waddell's "The Hazards of Sclentism" (1977) took strong issue with the basic philosophical orlentation of hazards research up to that point. citing the fact that the number of natural disasters has increased in the last 40 years, that the extent of their damage has also increased, and that most of this increase has occurred in the undeveloped and underdeveloped Third World (Thompson 1982), the articles argued that the economic as well as the ecological causes of natural disasters needed close analysis. The argument is speciflcally soclalist in its orientation and states that the causes of natural disasters are not outside human activity, but rather are intimately tied to capitalist development in the Third World--1.e., exploltation of both people and natural resources by the developed world and by minority elites of the Third World (Copans 1983; susman 1983; Watts 1983). This exploitation is seen as placing increasing pressure on the vulnerable environments of the 
earth through human activity, and creating hazards where none existed before, such as creating flood hazards through deforestation. In addition, economic exploitation places an increasing portion of the human population at risk of suffering the consequences of disaster, since it is the poor who are the least able to bear the brunt of natural disasters, and the impoverished portion of the human race is increasing. The new criticism wishes to examine precisely this process of increasing impoverishment, or "marginalization," of the world's population, in order to understand the source of suffering from natural disasters. Probably the culmination of this criticism, certainly its best exposition to date, is Hewitt's Interpretations of Calamity (1983) which is interestingly subtitled "From the Viewpoint of Human Ecology." This text makes the most cogent argument to date that the sclentific assessment of natural disasters, with its technological approach to hazard prevention and its assumptions about the orderly management of normal society, is an analysis which cannot be sustained in the face of mounting evidence of 1 ts cultural and political roots in the developed, and therefore exploiting, nations.

As a result of these criticisms, recent geographic research, such as Blaikie's The Political Economy of Soll Erosion in Developing Countries (1985), has concentrated on 
the political and economic roots of so-called natural disasters. However, it is important to go beyond social, economic and political "contexts" in which disasters occur, as these are not preordained givens. They are the results of ongoing dynamic interactions between human beings and their natural environment, and human belngs and their social institutions. They are the result of what Barrows called the "continuous evolution" of human activity in a specific place (Barrows 1923). Where a natural disaster, such as the 1985 Mexico City earthquake, is clearly not caused by human activity of any political or economic stripe, its consequences can still be assessed in political and economic terms, as the impact of the earthquake was not felt evenly across Mexican society, and the differences have political roots. The radical approach, so-named by Marston (1983), seeks a clearer understanding of the process of social system bullding in order to understand the relationship between natural disasters (causes and consequences) and "soclety" in all its dynamic, interacting, structure bullding complexity. For that, geographic research needs to draw on more than political economy, and it needs a much more dynamic and sophisticated model of social system creation and interaction than it has assumed until recently. 


\section{SOCIAL SYSTEMS IN GEOGRAPHIC LITERATURE}

It must not be forgotten that natural disasters happen in space and time to real people. In order to understand the effect of a natural disaster on society, it is necessary to know how the people involved are organized, as members of classes, castes, communities, tribes, clans, religions, ethnic groups, genders, how much political and economic power they have within their social context, and how conflict between the various groups is expressed, including spatially. Indeed, the question has shifted from a general one of "how do natural disasters affect society?" to a more specific one of "who suffers and why?" This question cannot be answered without a full understanding of the social process of a particular society.

social processes manifest themselves in the arrangement of social space. "It is now generally recognized that space is socially constructed and in its turn, once bounded and shaped, influences social relations" (McDowell 1983: 62). The issue of the soclal construction of space (the "structuration" of space) has received much attention in geographic literature in recent years. Indeed, soja calls the social construction of space "human geography in its fullest sense" (Soja 1979:4). This theoretical work draws on the works of Anthony Giddens, whose vast philosophy of soclology attempts to explicate the interweaving of the 
individual with the institutional structures of $\mathrm{his} / \mathrm{her}$ society. It also draws on the work of Torsten Hägerstrand, whose geographic research on innovation diffusion was leading him to an understanding of the weaving of the individual into the spatial structures of his/her soclety. Geographers such as Gregory (1985b), Moos (1986a, 1986b), Pred (1981, 1984), Thrift (1983), and others have attempted to put the two strands of thought together. The goal is to analyze how Individuals, as thinking and acting members of, and products of, their soclety, come together within the context of the institutionalized social and spatial systems into which they are born, to recreate but constantly modify their social and spatial order. The root problem of this geographic research is to ldentify how the everyday paths of ordinary individuals are shaped by, recreate and modify the underlying but constantly developing social and spatial relationships of that particular society (Gregory 1985a).

One weakness of this theoretical work is that it has not been applied to very many unique historical cases or events. Moos (1986b) applied the ldeas of structuration to the creation of a "ghetto" of mentally ill patients in one Canadian city. Pred (1985) analyzed the relationship between enclosure of fields and social change in a rural county in sweden. This paper suggests that the 1985 earthquake of Mexico City and the events immediately 
following it offer a very good opportunity to examine some of the theoretical ldeas outined above from the perspective of an actual historical event, or rather, an actual social process.

First, Mexico City is a prime example of what Thrift (1983) calls an "interaction structure." It is the result of thousands of years of human interaction, which profoundy shapes the Iives of Mexico's people, both inside and outside the city. It most certainly shaped the lives of the people involved in the conflicts in the garment district, both before and after the earthquake. Mexico City is not a neutral place in which events occur, like a flat stage with a painted curtain for a backdrop. Mexico City can almost be seen as an active participant in the events themselves. Certainly, it is a node of human interaction on a massive scale and an earthquake in this setting will affect the lives of millions of people. The 1985 earthquake affords an opportunity to examine how and why those lives were affected.

Second, if the process of capitalist industrial development does indeed have any relationship to who suffers from a disaster and why, the earthquake in Mexico city should provide a useful example. Mexico is a developing country which has experlenced rapid economic growth in the last flfty years and at the same time is suffering from 
extreme disparities in the distribution of its wealth. Massive soclal change caused by Mexico's economic development has led to the emergence of a new class, which this paper refers to as Mexlco's "working poor." The costureras are a prime example of that newly emergent class. An analysis of the creation of the "working poor," and their position within Mexico's political and economic institutions, will throw light on how the poor are made more vulnerable to disasters through the workings of the soclal system into which they are born and through which they must act.

Third, this particular event affords the opportunity to examine the fundamental question of structuration theory, that of the relationship between thinking and acting individuals and their determining social system, including its spatial expression. Thrift (1983) has identified the labor process as the place where the two movements--that of the individual in his or her daily path and that of social structure in its process of constantly reproducing itself-meet. It is in the workplace that real people meet on a daily basis, as members of their class, caste, community, and gender, within a system of soclally produced and reproduced institutions, to produce and distribute their material needs. This dally meeting for reproduction and survival reproduces, but constantly modifles, their social 
order. Marston (1983) also identified the labor process as the focus for understanding the impact of natural disasters on societies, for it is through the labor process that humans interact with nature in order to extract, produce and distribute their material needs. Thus, social processes, Including conflict and change, can be found in the labor process.

Edwards, in The social organization of Industrial Conflict (1982), ldentlfles three levels of conflict in the workplace: overt (both directed and non-directed), institutionalized, and implicit. Overt conflict is recognized and acted upon; institutionalized conflict is also recognized, but is mediated through rules, contracts and understandings, both formal and informal; and implicit conflict is not acted upon and may or may not be discussed or even recognized, but it nevertheless exists. The most obvious form of implicit conflict is the need for capital constantly to increase production from workers and constantly decrease costs, whereas labor needs constantly to protect itself from increasing exploitation while maintaining or improving its position in the labor process. This implicit conflict is built into the social organization of production processes, and into their spatial organization. 
The Mexico Clty garment district provides an opportunity to examine the role of implicit class and gender conflicts in the creation and dally operation of a place of work. Whatever conflicts existed in the overall social context, conflicts which were played out in the creation of the city, existed in their own form within the district and the garment factories as well.

Finally, the events immediately following the earthquake throw light on the issue of fust how the earthquake, as a natural disaster, affected ongoing social process. In particular, the role of the natural disaster in changing implicit conflict to overt conflict can be examined. This can be done by analyzing the earthquake's affect on spatial structure, in which the dynamics of a particular social system were deeply embedded.

The analysis described above weaves a web of many theories, but social process is a complex web of history, ideology, psychology, chance, conflict and resolution, which creates a built environment, a material reality, in which the next generations are born and with which they must operate. Marx said "Men [sic] make history, but not in circumstances of their own choosing" (Thrift 1983: 32). simple theories cannot be applied to complex processes. The following work is meant not so much to explain what happened 
from the viewpoint of theory, but to shed light on theory from the viewpoint of actual events.

\section{STRUCTURE OF THIS PAPER}

This paper starts with a particular situation among particular people in a particular place and traces the historical interactions that brought them together on the day of the earthquake. The three coalitions of actors within the garment district were the costureras, the shop owners and the federal government. Each of these sets of people represents broader social institutions, those of the worklng poor, capital and the state. The historical development of these broader institutions, and their interactions in the creation of Mexico city, grow out of basic unresolved conflicts that have their roots in the Revolution of 1910-1917. Though the Revolution has deep nistorical roots, that conflict affords an historical boundary for this research. The garment industry in Mexico City was built by people involved in the social and economic tensions of Mexico's development. The earthquake, by altering the spatial patterns of daily life and by creating an emergency situation to which all parties had to respond, forced those implicit conflicts to the surface to be expressed in new ways. 
Chapter II sets Mexico city in its physical landscape, and describes the city's history of earthquakes. It also discusses the growth of Mexico City as a place which reflects Mexico's political and economic centralization and describes the creation of the garment district within the city. Chapter II argues that the reasons conflict in the garment district turned into political protest have much to do with Mexico's historical relations between government and labor, and in particular the conflict represents an ongoing weakening of the traditional "bargain" between those two sectors. Chapter IV argues that the response of the costureras to the earthquake has deep roots in the economic development of Mexico and in the resulting demographic changes. In particular, the chapter argues that the women were in a particularly weak position relative to both capital and government, and the earthquake placed them in the contradictory position of having nothing left, and yet needing to fight the hardest to maintain their position in the system of production. Chapter $V$ argues that the owners and government also had conflicts of interest, which determined the way that each of these sectors responded to the earthquake. Chapter VI draws upon a broad array of social sclence theory to analyze the role of the earthquake as a separate event in creating social change, and makes 
suggestions for geographlc research based upon the conclusions of this paper.

\section{METHODOLOGY}

The materials drawn upon for this research are mostly archival. Research was done during two trips to Mexico City, in August and September of 1986 and February and March of 1987. Interviews were conducted with costureras and with women who had organized their support, and with the following people: Elena Urrutia, an editor and founder of fem magazine and professor of women's studies at Colegio de Mexico; Silvana Levi de Lopez, a geographer who has done research on land use in the central district of Mexico City; Sr. Taverna of Grupo Textil Cadena, the state-owned corporation in the textile and garment industry; sr. Alefandro Gomez of INEGI, from whom air photos of the district and INEGI reports on the textile and garment industries were obtained; Teresa carrillo, a researcher from stanford University writing her dissertation on the costureras; Lisa Block, a development worker in Mexico City; and Mary McGill, of the Mujer a Mujer (Woman to Woman) program.

For primary materials, heavy rellance has been placed on newspaper accounts in La Jornada, El DIa, Excelsior, and Uno Mas Uno, 4 all of Mexico City. Primary materials also 
include papers and leaflets written by the costureras, and articles written about them by the people who were actively involved in the crisis of the earthquake and the formation of the Union.

For the rest, both Spanish and English resources on the garment industry in Mexico were sought, including government reports, trade publications, and research articles in scholarly journals. Recently published books and articles were relied on for discussion of Mexico's political and economic system, and its history. For theoretical background, sources in both hazards literature and society-and-space literature were researched. The research was conducted from January through May of 1987 , though it is this writer's hope that this process is only the beginning of a lifelong acquaintance with an interesting and important country and its people. 


\section{CHAPTER II}

\section{MEXICO CITY AND ITS EARTHQUAKES}

Mexico City is so closely identifled with the nation of Mexico that a crisis in the city is a national crisis and a national crisis is likely to be played out in the arena of the city. This identification is expressed in the fact that most of Mexico's population, capital, political bodles and Industrlal production are concentrated in the Mexico city area. Early in the nineteenth century Mexico city was declared a Federal District, much like Washington, D. C., and the administration of the city was placed directiy in the hands of the federal government, where it remains today. The mayor of Mexico Clty is appointed by the president of the nation, and the city's administration is a ministry of the federal government.

Mexico City is located at 19.24 degrees north latitude and 99.09 degrees west longltude (F1g. 1), and at approximately 8,000 feet above sea level is one of the highest capital cities in the world. It is also one of the largest cities in the world, with an estimated population of 18 to $20 \mathrm{mililion}$ people, a population that is expected to reach 32 to 40 million by the year 2000 . Mexico city has a 
primacy ratio of $5.18,1 . e .$, it is 5.18 times larger than the second largest city of Mexico, Guadalajara (Brunn 1983). The city sits in the Valley of Mexico, surrounded by high volcanoes, and is bullt on the unconsolidated solls of an old lake bed. Its sinking and tilting buildings, placed on unstable foundations, have been well-known for many years.

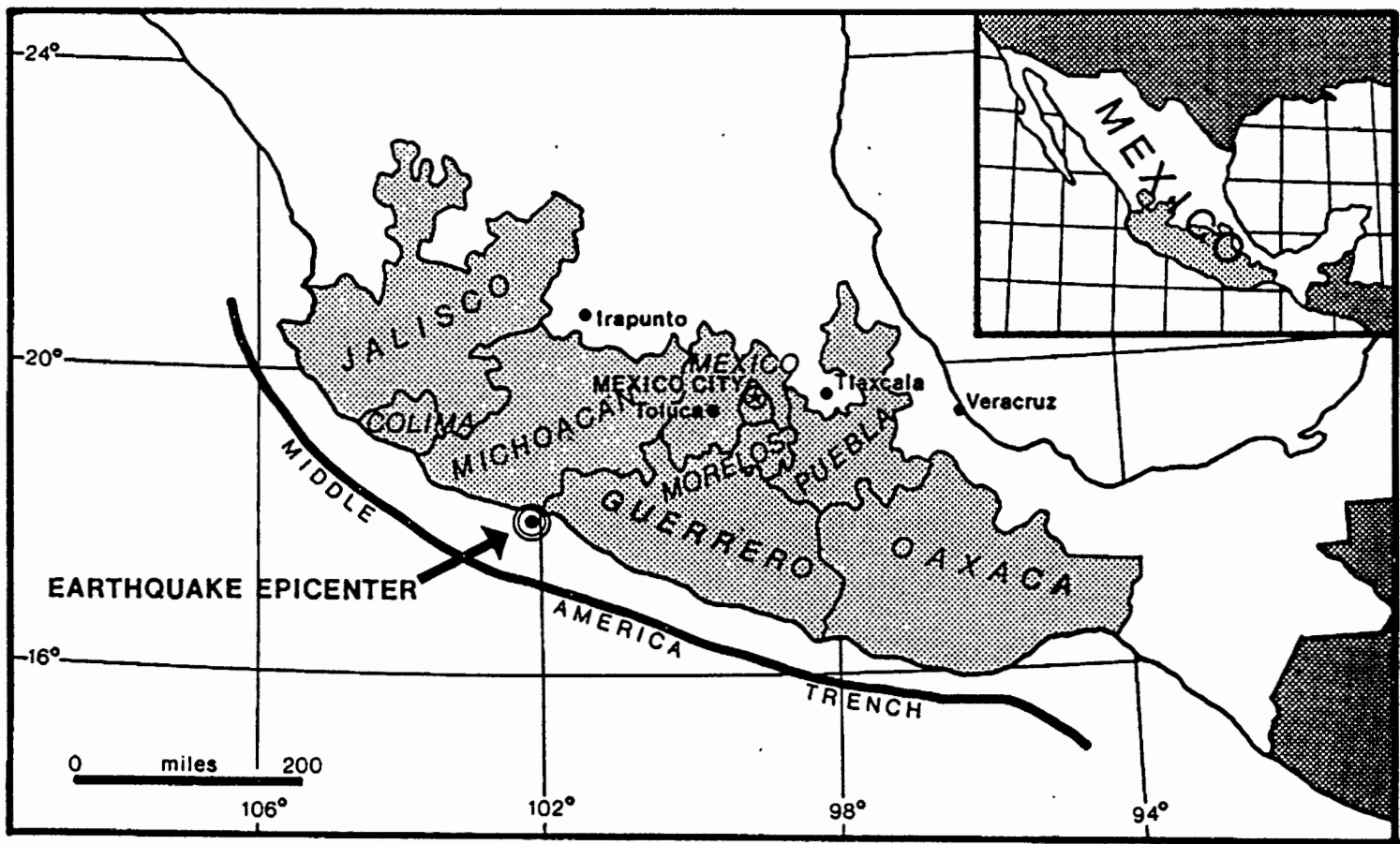

Figure 1. Mexico City, the eplcenter of the earthquake, the Middle American Trench, states in which damage occurred. 
In approximately 1325, when the Chichimec people of northern Mexico moved into the region of Lake Texcoco where the Teotihuacan and Toltec civilizations had already flourlshed and died, they in many ways sealed the fate of the nation of Mexico. The Chichimecs chose to settle on an island in the lake, and within less than 200 years, they had built the Aztec Empire by subduing, and extracting tribute from, a widening circle of neighboring peoples. They also began to fill in the lake in order to use the land for agriculture. When the spanish arrived in 1519, they picked off the leader of this powerful and centrally located empire, and placed themselves in the very center of one of the New World's two most advanced civilizations.

The city grew slowly during the colonial period, primarliy because it did not bulid up an indigenous economic base. The city was used by the spanish for military and administrative headquarters. The colonizers put their efforts into extracting silver and raw materials from Mexico and shipping them to spain. The profits from this extractive activity were used to build a system of large estates for the colonial landlords, estates which were not meant to produce goods for agricultural trade, but which were built on a feudal model: extensive family-owned land holdings, access to temporary labor by native Indlans, and little exchange between estates. The Indian peoples lived 
in their traditional communal villages, but their land rights were always precarious, as the colonial landowners regularly extended their clalms to property, based on their economic interests at the time. Money invested in Mexico city itself went into impressive administrative bulldings, cathedrals, parks and palaces. The city became known as one of the most beautiful in the world. Its expansion, slow as it was, was accomplished by draining the lake and bullding on top of its solls. The dralnage was never entirely successful, however, and the solis under the center of Mexico Clty are saturated with water, requiring continuous pumping.

This weak foundation has meant that Mexico City is particularly vulnerable to damage from Mexico's frequent earthquakes. The Middle American Trench, formed where the Cocos Plate meets the North American Plate, runs parallel to the southern coast of Mexico (Fig. 1), and it is the subduction of the Cocos Plate under the North American Plate that is the source of Mexico's many earthquakes. This boundary between the two plates is known to be one of the most active plate margins in the world (Degg 1986). The nation suffers innumerable earthquakes of varying magnitudes every year, including eight in this century of magnitude 6.2 or more on the Richter scale. Mexico city suffered major earthquakes in 1845, 1911, and 1957. From 1729 to 1961, 
there were thirteen occurrences of earthquake damage in Mexico City, averaging one every elghteen years (Peck 1985). Although the epicenters of these earthquakes are rarely under the city, and are indeed often two hundred to four hundred miles away, Mexico city's quivering solls respond disproportionately to the vibrations set off by earthquakes. The epicenter of the earthquake that began at $7: 19$ a.m. on september 19, 1985 lay 250 miles to the south and west of the city, at 17.6 degrees north latitude and 103.5 degrees west longltude (Fig. 1). There were few immediate aftershocks, but approxlmately 36 hours later, on Frlday, the 20th of september, a second earthquake, measuring 7.5, shook the clty. These two events together are known as the September 19 earthquake, as the second one is thought to be. an aftershock of the flrst (Peck 1985). Damage occurred in the states of Jalisco, Michoacan, Guerrero, Colima, Morelos, Oaxaca, Puebla and Mexico (Fig. 1), but by far the most extensive damage was in Mexico City. The first earthquake consisted of two slxteen second thrusts along 150 miles of the North American Plate, approximately twenty seconds apart. The shaking in the city, however, is variously reported to have lasted from 90 seconds to three full minutes. The difference in length of time was caused by Mexico clty's "bowl of jelly" dynamics. The fxequency of the earthquake vibrations in thls particular case, 
approximately two seconds apart, colncided with the resonance period of the solis under the center of the city, whlch had the effect of amplifying the resonance of the earthquake vibrations by four or flve times (Kerr 1985). The effect was the same as repeatedly pushing a bowl of water at exactly the same time that its sloshing moves the water up one side of the bowl.

Various estimates put the number of buildings destroyed between 300 and 1000. Degg (1986) conservatively reports 200 destroyed. The number of damaged buildings is estimated to be between 2,000 and 3,000 , based on different criteria for assessing damage. The damage appears to have been highly selective. Bulldings between flve and flfteen stories high were especially hard hit, because their resonance period matched that of the soll on which they were built, which further amplified the resonance of the ground tremors. Shorter bulldings in effect "rode out" the shaking, while taller ones were able to "pass" the vibrations "up and out." The five to fifteen story buildings were tall enough to be shaken but not flexible enough to throw off the effects. Many of those buildings were government buildings. All five major hospitals of the city were badly damaged, three of them totally destroyed. Aproximately 250 schools were damaged enough to be closed, leaving one million school children out of school. The 
central telecommunications facility collapsed. The computer center of the office of the Budget was destroyed, causing the loss of the nation's financlal planning records for 1986-87. A major housing project, Nueva Leon, collapsed, klling at least one thousand people.

Mexico City has one of the toughest earthquake building codes in the world, passed in 1977 and based on the experience of the 1957 earthquake. However, there is serlous doubt that these codes were enforced. Further, the federal agency established in 1977 to deal with natural disasters of this sort had been abolished in 1982, as an austerity move. Whether the government was simply unjucky in constructing buildings of five to fifteen stories, or whether there was corruption in the awarding of building contracts and the enforcement of the bullding codes, public perception was that of government inefficiency and malfeasance.

Public disillusionment with the government was reinforced by the obvious Inability of the government to deal effectively with the emergency. Offers of rellef assistance came from around the world, but the government delayed for several days in agreeing to accept this aid. When it arrived, there were no agencles prepared to distribute $1 t$, and relief agencles told stories of Inexcusable delays and mismanagement. The United States 
Congress offered an immediate $\$ 25 \mathrm{million}$, but only $\$ 4$ million was sent; the government of Mexico delayed so long In asking for the assistance that its request came six days after the six-month deadine for such requests. The extreme centralization of Mexico's resources in one place makes it especially vulnerable to natural disasters. At least 70 of Mexico's financial transactions occur within Mexico City (Rudolph 1984), and of those, some $80 \%$ occur within Delegacion Cuauhtemoc, a central administrative district of the city. This district suffered major damage from the earthquake. Of the nation's 500 largest corporations, 718 have their headquarters in the Mexico City area (Expansion $8 / 15 / 84$ ). Mexico City contains one-quarter of the nation's elghty million people, contributes $44 \%$ of the nation's gross domestic product, $50 \%$ of its Industrial output, is the central working and living place of two-thlids of the federal government's workers, and holds 80 of the nation's flnanclal assets (ECLA 1985; Riding 1985). Approximately two-thirds of the nation's students go to school in Mexico City. The earthquake made clear once again that Mexico's extreme centralization needs to be addressed. Public commentary both within and outside of the country strongly volced the oplnion that Mexico needs to decentrallze, and placed the responsiblilty for that 
decentralization squarely with the federal government (WSJ $10 / 4 / 851$.

However, there are very real reasons that this concentration of population and resources has developed in Mexico, reasons which cannot be counterweighed by government edict. Among those reasons are historical development, industrial infrastructure, and capital concentration. Like many newly industrialized countries that have experlenced rapid growth since mid-century, Mexico's extreme centralization is closely tied to the loglc and needs of capital accumulation. The results have been a clty that Alan Riding (1985) calls a "magnet and a monster."

ECONOMIC GROWTH AND THE GROWTH OF THE CITY

There is a close correspondence between the growth of Mexico City's population and the growth of the nation's economy. The annual average growth rate of the economy of Mexico from 1940 to 1950 was 6.98 whlle the growth rate of Mexico City was 5.48 per year. During that decade, 1,385,000 people moved to Mexico C1ty (Pommlex 1982). A similar pattern has held for every decade since then (Pommier 1982). If Mexico City reaches its expected population of 32 million by the year 2000, it will have grown 10018 between 1950 and 2000 (Brunn 1983). 
Untli the 1960's, Mexlco City was virtually synonymous with the Federal District, as the entire city was within the boundarles of the Distrlct (FIg. 2). However, since the late $1960^{\prime} \mathrm{s}$, most of Mexico City's growth has been in the municipalities surrounding the district that lie within the state of Mexico (Fig. 2). The population growth of the surrounding munlcipalities has been nothing short of phenomenal (Table I) and continues unabated. The source of

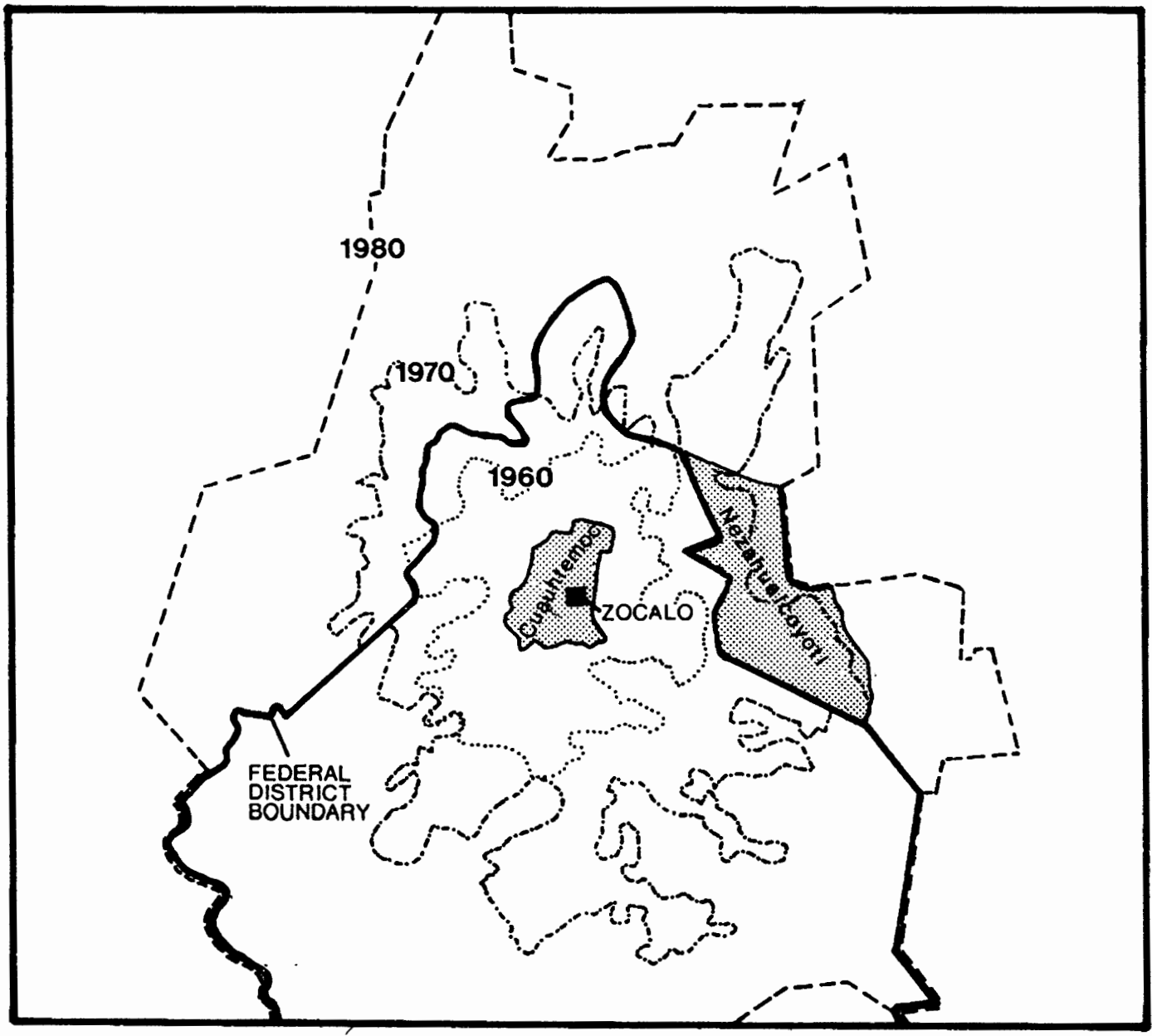

Elgure 2. Mexlco City Urban Area, 1960, 1970, 1980. 


\section{TABLE I}

\section{POPULATION WITHIN THE FEDERAL DISTRICT AND MUNICIPALITIES OF THE STATE OF MEXICO}

$\begin{array}{lcc}\text { Year } & \text { Federal District } & \text { Municipalities } \\ 1900 & 344,700 & 000 \\ 1920 & 661,700 & 000 \\ 1930 & 1,000,000 & 000 \\ 1940 & 1,800,000 & 000 \\ 1950 & 4,000,000 & 000 \\ 1960 & 5,000,000 & 230,000 \\ 1970 & 7,000,000 & 1,800,000 \\ 1980 & 9,000,000 & 5,500,000 \\ 1982 & 9,200,000 & 7,000,000\end{array}$

(Sources: Alvarez 1985; Iracheta 1982; Pommler 1982; I. Scott 1982)

the migration has been, and continues to be, the rural population, and the goals are jobs, a plece of land, and a better $11 \mathrm{fe}$.

The growth of the city can be described as a race between the rich, the poor and the rapidly growing middle class. During the decades between 1940 and 1960, the bulk of the new jobs in Mexico city were in construction (Pommier 1982). Land speculation was uncontrolled and as a result, the city's growth has been erratic, developing mismatched enclaves of the very rich and the very poor. Shopping malls are mixed with industrial areas, and both are interspersed with squatter settlements and idle land. The government has tended to endorse the land grab after the fact. It provides basic services to commercial and residential developments of the middle classes and the developers, and "regularizes" 
(makes legal) land holdings by squatters. Recently, however, the government has changed its policy. Its Urban Development Plan of 1980 stipulates that no further settlements will be regularized and that by 1988 all 11 legal settlements in Mexico clty (proper) will be shut down (Pommier 1982). Though there has been some question as to the effectiveness of thls program (ward 1985), the expulsion of poor squatters has been credited for at least part of the phenomenal growth of the munlcipalities surrounding the city (Fig. 2; Table I). Nezahualcoyotl, one of Mexico City's most famous squatter settlements (F1g. 2), has grown to a population of 3 mililon since 1960 and in the year 1976-77, experlenced a $5008 \times$ lse in rents (Moreno Toscano 1982 ). It is now possible to speak of the "marginated of Neza," or those squatters who are too poor to IIve in a rapidiy growing settlement and who therefore must 1 ive even farther out.

In 1970, the federal government consolldated several separate administrative units within the Federal District into Mexico City, and to date the 1970 boundaries constitute Mexico City "proper" (FIg. 2). The government has virtually ignored the municipalities surrounding the city, within and outside the Federal District. The result is that there are two basic governments administering Mexico city: the federal government within the Federal District, and the state of 
Mexico outside the Federal District boundaries. Within those two divisions are dozens of municipalities. Every day, millions of people must negotiate among separate bus systems to get from their homes to their jobs. They must apply to several different government agencies for social benefits, or permits and licenses; the provision of basic services such as water, sewers and electricity is divided between dozens of municipal units.

In the urban setting, the relationship of the urban poor to the government is a complex one of demand-making and accomodation between popular organlzations and the federal bureaucracy (Castells 1982; Cornelius 1974; Ward 1986). Essentlally, the poor must spend years petitioning, organizing, sitting-in at offices and repeatedly visiting political headquarters in order to obtain basic services. None of this is a serious challenge to the government's central authority, however, and bureaus and government workers play one poor nelghborhood against another, enriching themselves from bribes. Eventually nelghborhoods do get their services, in exchange for which they promise to support Mexico's one political party. Thus, where there is an appearance of radical protest and arganizing in the form of the many marches, demonstrations and sit-ins that the working poor must make, the reality is that this is the only way within the system to obtain necessary services. This 
system also means that the government does no planning or managing, and provides no leadership; it only responds to crises and demands.

Ironlcally, the federal government's attempts at decentralization have caused much of this chaos. Realizing as early as 1954 that the clty needed to be decentralized, the federal government, in one of its industrial promotion plans, established tax breaks for industries that located outslde of the Federal District (Pommier 1982). Industries began locating just outside the Federal District boundaries In order to galn the tax exemption while staying close to the nation's economic center. They took with them the Inevitable squatter settlements of newly arrived migrants seeking industrial jobs. In addition, the act of setting boundarles around the growing municipalities stimulated intense land speculation within the new city limits while squatter settlements sprang up fust beyond the municipal boundaries, where land was cheaper. Thus the government's attempts at decentralization have had the effect of abandoning responslbility for major sections of what operates as one labor and consumer market (Moreno Toscano 1982 ; Pommier 1982). 
THE GARMENT DISTRICT OF MEXICO CITY

Mexico's economic growth was originally based on a policy of substitution of locally-produced goods for imported consumer goods, for sale to the national market (Dominguez 1982). Light industry such as the garment industry were especially encouraged (Pommier 1982).

Although there had been apparel shops and textlle industries in Mexico for many years (EI Dia 10/9/85; Ramos 1986), the real time of "take off" for the garment industry was the mid-1940's (Alonso 1983; Pommier 1982). This explains why the garment district of Mexico City is located so close to the center of the city, almost side-by-side with the nation's federal buildings (Fig. 3; Table II). The apparel industry needs to be centralized, because of its complex web of contract relationshlps and network of speclallzed businesses. In 1940, the city was very much smaller than it was in 1985, and government and financial resources for industrial centers such as the garment district were avallable only in the center of the clty. Over the last 45 years, the nation's industrial policy has shifted towards favoring more advanced technology, and for a number of reasons, hard times have hit the garment industry (chapter v). In addition, other uses for the central area compete with the garment district. The federal government has made It a priority to move Industry and some types of commerce 


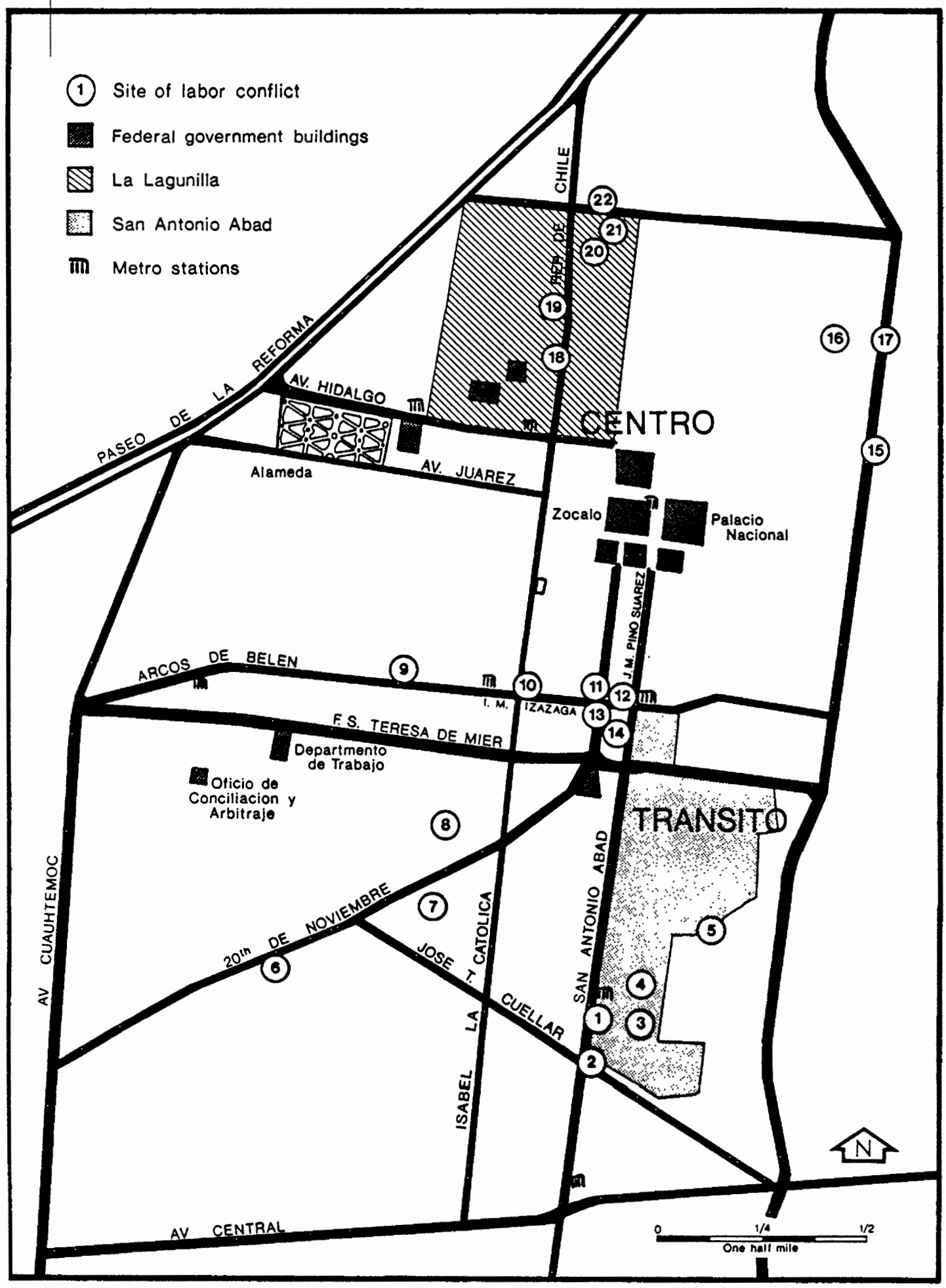

Fiqure 3. Garment district of central Mexico City. 


\section{TABLE I I}

SITES OF LABOR CONFLICTS, BY LOCATION AND NAME OF BUSINESS

site

1.

2 .

3.

4.

5.

6 .

7.

8.

9.

10 .

11 .

12 .

13 .

14.

15 .

16 .

17.

18.

19.

20.

21 .

22.

\section{Location and Name of Business.}

138-164 San Antonio Agad. Dimension Weld, Topeka, Amal, Carnival, Le Petit, Creaciones Lody, Baby Duy.

San Antonio Abad and Jose T. Cuellar streets. The encampment of the costureras.

186 Manuel J. Othon. Kayser.

26 Agustin Delgado. No name given for shop.

75 Clavijero. Pascual Bottling Company.

260 Garcla Dlego. RopaMex.

Bollvar and Boturinl streets. Pantalones Ideal.

Bollvar and Aleman streets. Deval.

80 Eje Lazlo Cardenas. No name given for shop.

55 I zazaga street. Miss Universe.

175 20th de Noviembre. Plamonte.

137 Izazaga. Confecciones Yanet.

151 20th de Noviembre. D'Galia.

130 Nezahualcoyoti. Sisi.

Alarcon street. No name given for shop.

Doblado street. No name given for shop.

J. J. Herrero street. No name given for shop.

Belissarlo Domingo and Rep. of Chile. Nueva York. 87 Peru street. No name given for shop.

Rep. of Ecuador street. star Dance.

77 Rep. of Ecuador. Maquilas Serrat

153 Palma Norte. Gales Shlrts.

( See Appendix A)

out of the center of the city in order to make the historical center more attractive for business and finance, government, and tourism. However, the garment district lingers on, through inertia, a kind of seedy monument to Mexico's economic take-off. 
One feature of the Center and the San Antonio Abad (Colonia Transito) regions, which make up the garment district (Fig. 3), is the mixture of residential, commercial and industrial uses, and the varlety of types of shops within the districts. Sewing shops are often located on the second floor of bulldings used for other purposes (Figs. 4 and 5). Heavy sewing machlnery located on the upper floors of buildings orlginally bullt for housing and small shops probably contributed to the collapse of the bulldings. shops run the gamut from very small shops (Fig. 6) to several mid-sized shops in one bullding (FIg. 7), to large modern industrial buildings (Fig. 8). In addition, the shops do not make fine distinctions between types of commercial activity. A very common sign in these areas reads "clothing, by the piece or wholesale" (Fig. 9). These small shops are probably the source of much of the contracting from the central district, and the sight of small contractors delivering their finished goods is also not uncommon in this district (Fig. 10).

Garment factories often appear over clothing stores (Fig. 11). Where clothing stores show up as retail outlets on the first floors of a district, one can surmise that there is a good chance of flnding sewing shops above at least some of them. In the La Lagunilla subarea of the Center (F1g. 3), Levi de Lopez (1981) found that clothing 


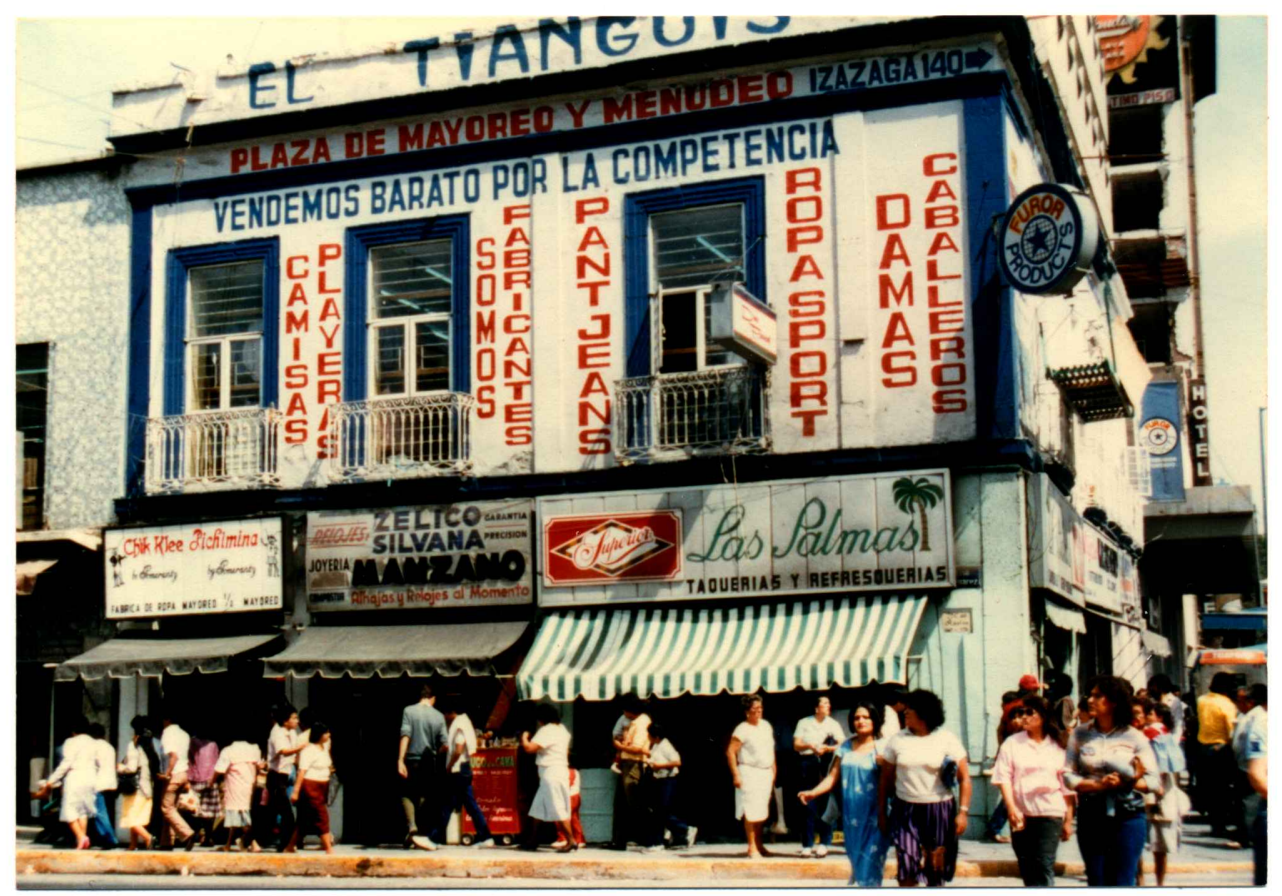

Fiqure 4. Garment factory above retail stores.

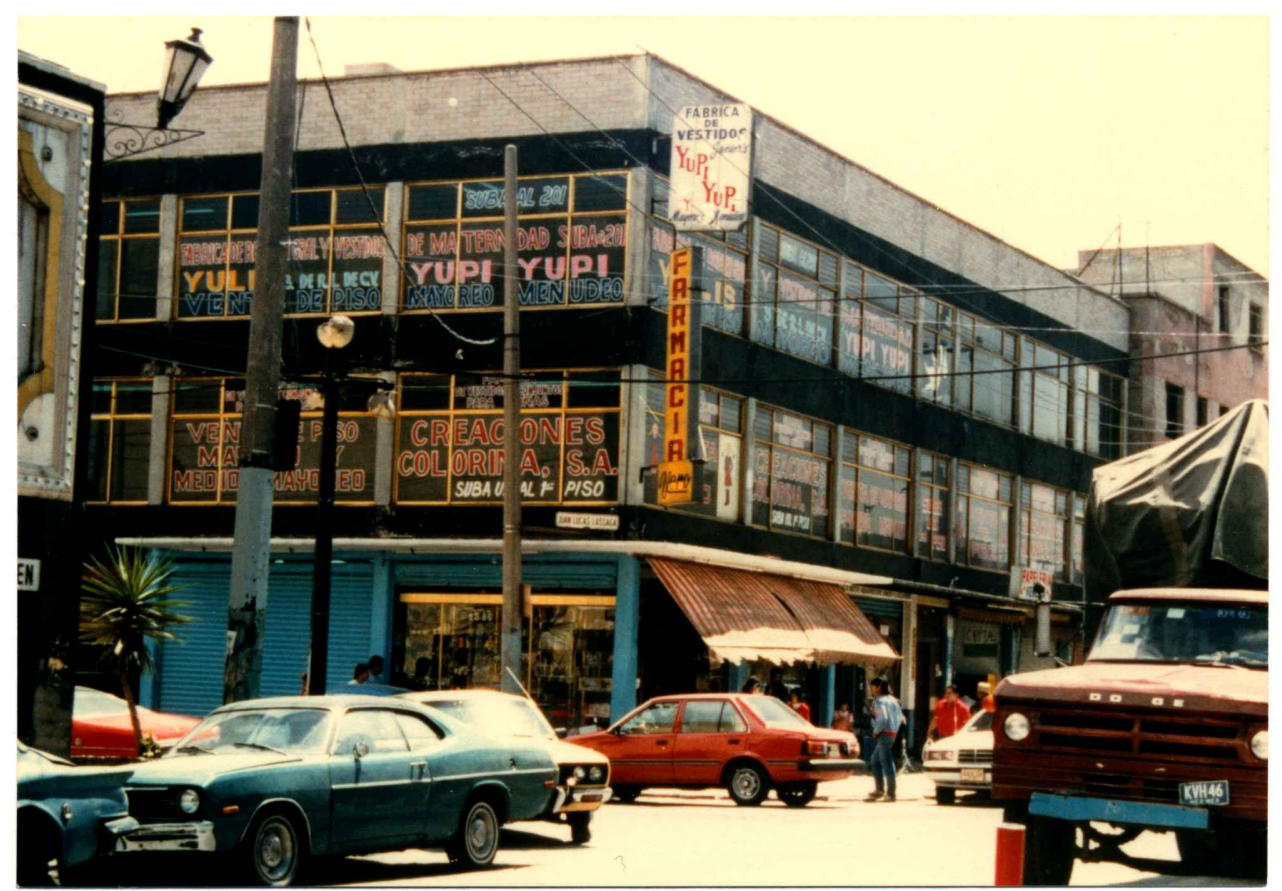

Figure 5. Garment factory above pharmacy. 


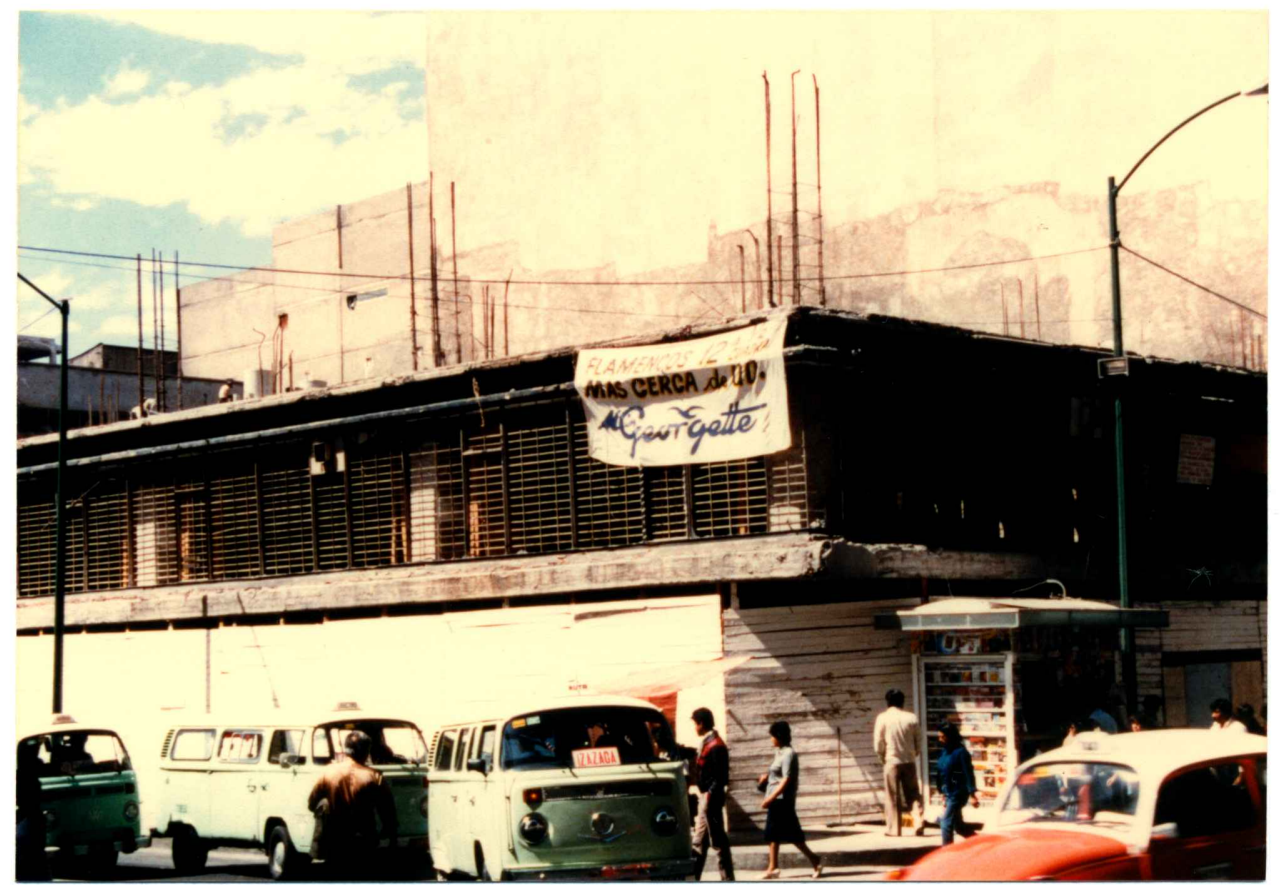

Figure 6. Small garment factory.

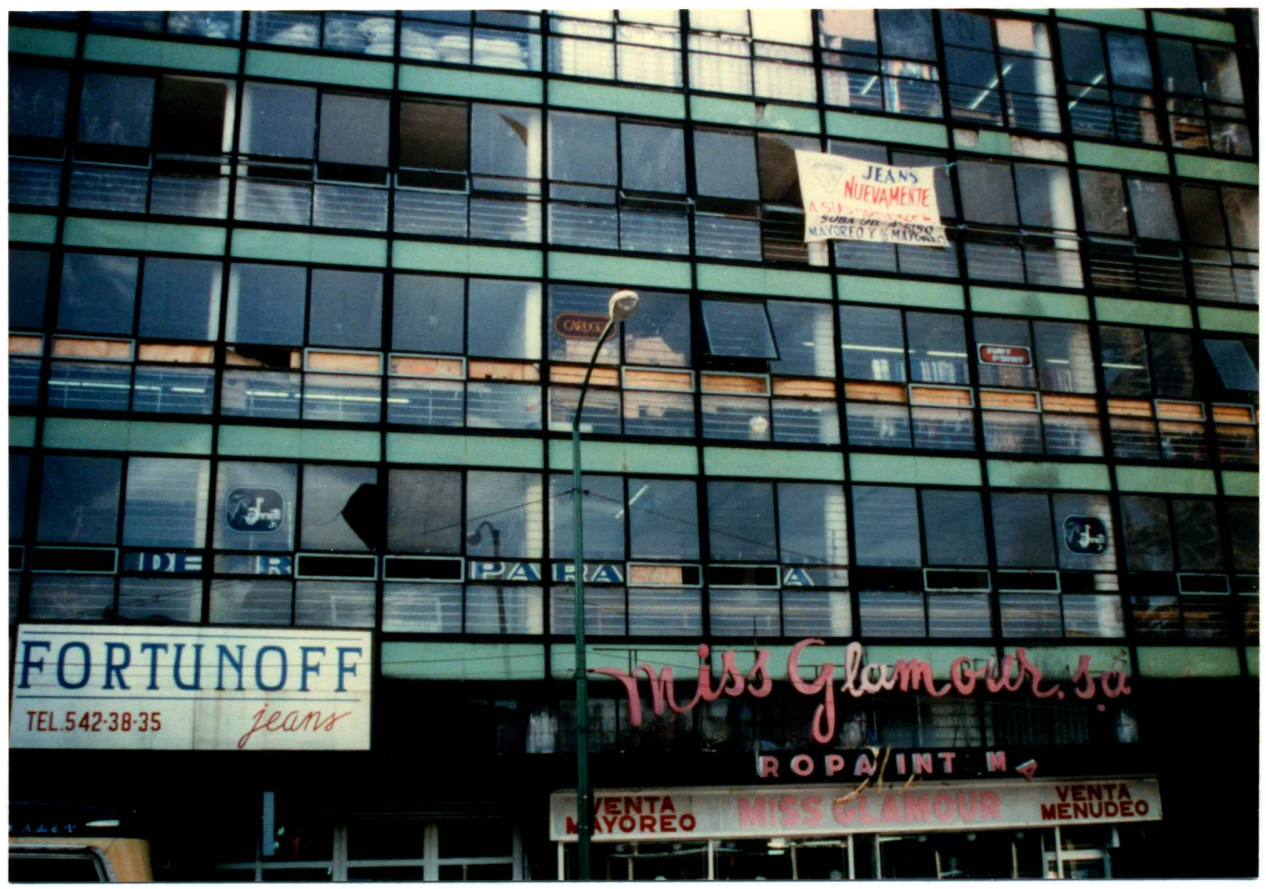

Figure 7. Several mid-sized factories in one building. 

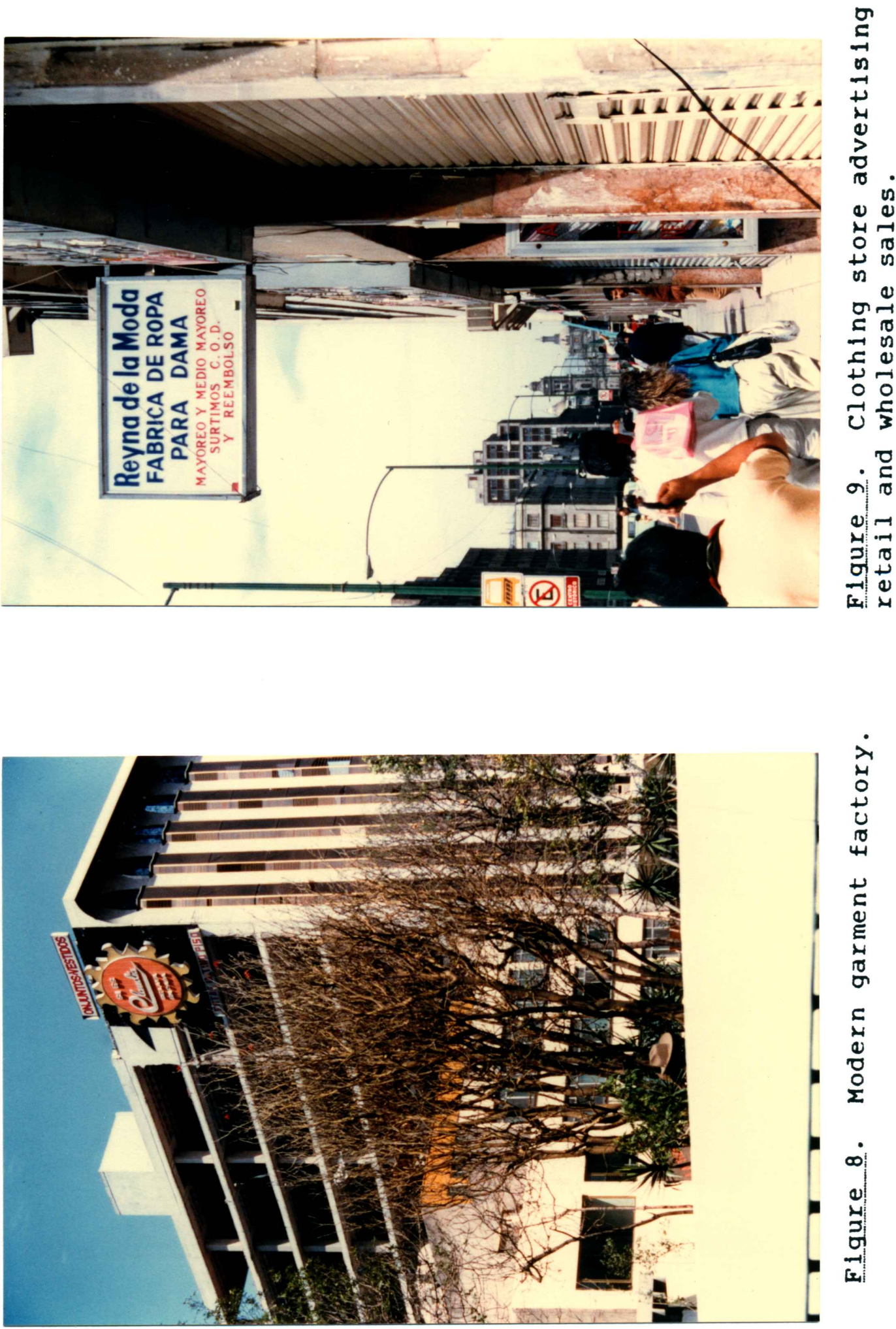

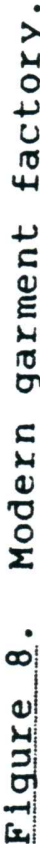




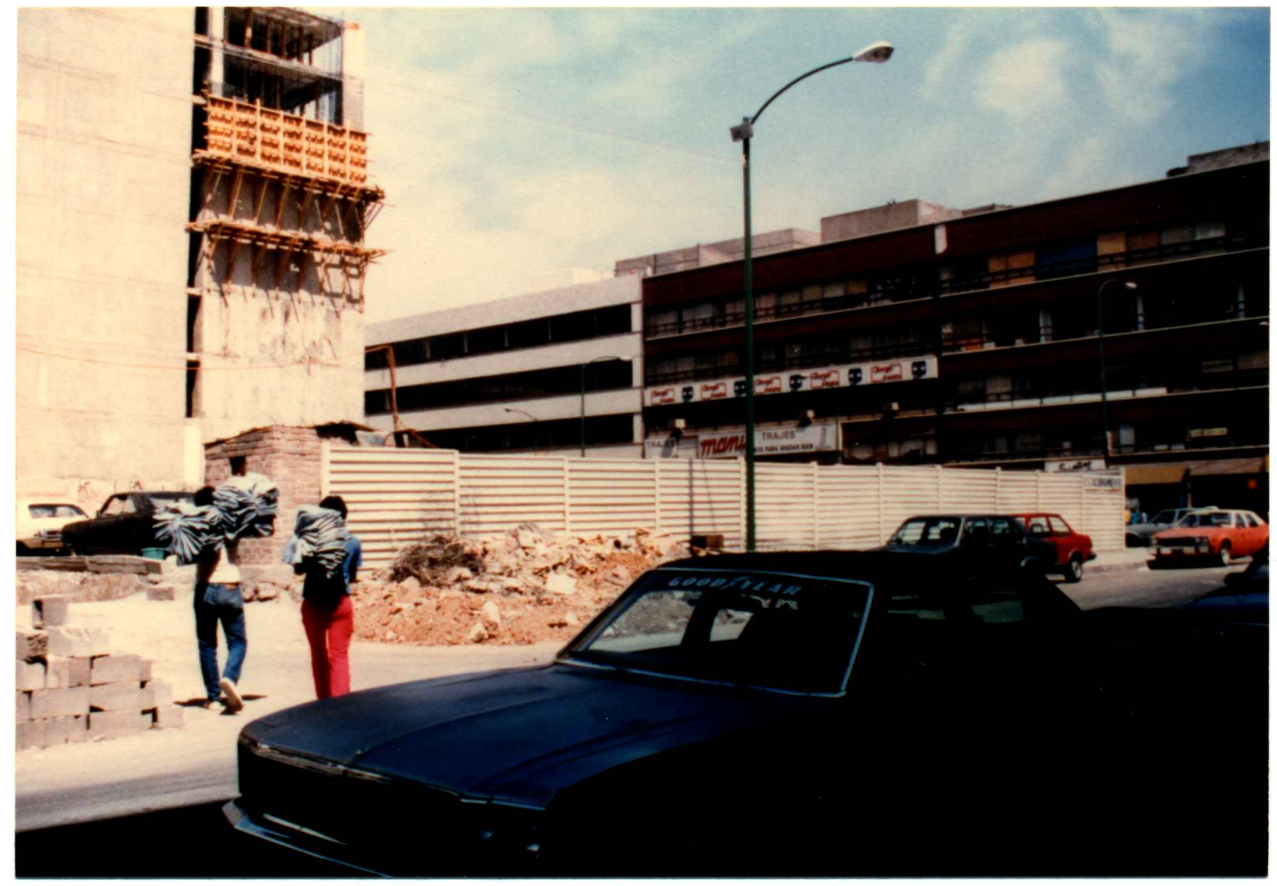

Figure 10. Independent contractors delivering goods.

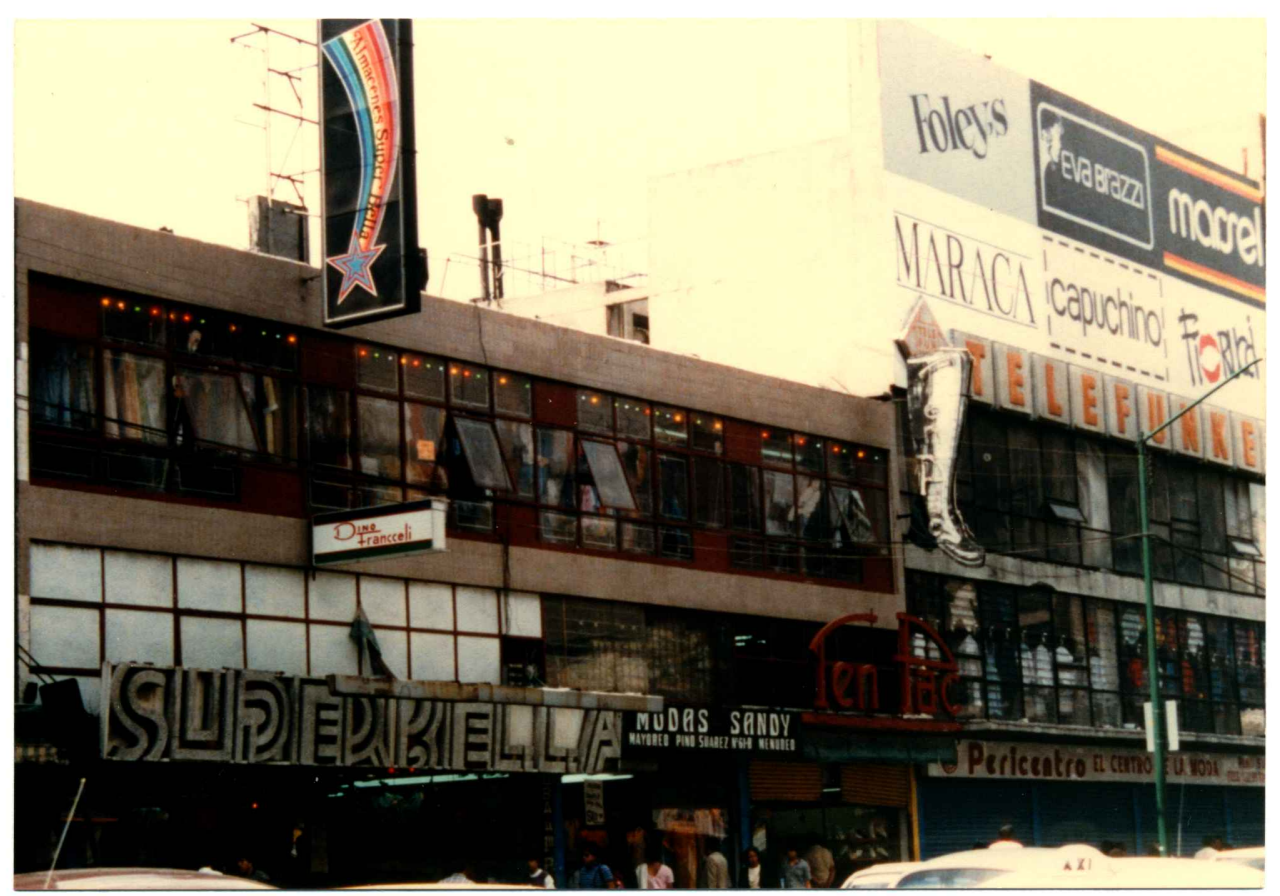

Fiqure 11. Garment factories above clothing stores. 
stores made up the largest number of commercial enterprises of the subarea, amounting to $28 \%$ of the establishments. It is not surprising, then, to find several of the actions of the costureras after the earthquake occurred in this same area (FIg. 3; Table II).

Mexico's garment industry has a great variety of workshops and factories, in size, in number of employees, type of equipment, and type of garments produced. It is made up of "a long chaln of subcontractors" which plece out work as far down as the individual worker in her squatter settlement home (Alonso 1983). The majorlty of these shops are clandestine, or illegal, unregistered shops. The clandestine nature of the apparel Industry in Mexico is one of its primary features. The official figures for employment in the garment industry run around 102,000120,000 (INEGI 1984, 1986; Perez Sanroman 1986; Saenger 1986), and yet the estimated flgure for the actual number of women employed in garment factories in Mexico is consistently reported to be 700,000 (El DIa $6 / 15 / 86)$. Approximately 508 of these women work in clandestine factories, which make up 80 of the garment shops in Mexico (Uno Mas Uno 10/18/85). These shops do not pay minimum wages, Social security or any other benefits to which workers are entitled under the Mexican Labor Law, and they do not meet minimum standards of health and safety in their 
working conditions. "Clandestine" does not mean invisible, it only means unregistered. Many of the shops shown in Figs. 4-11 are probably "clandestine," though clearly they are visible and their existence must have been known to many thousands of people.

clandestine shops keep wages low even in the reglstered factorles. At a time when legal minlmum wages was 20,000 pesos per week (1985-86), the costureras were earning between 5,000 to $10,000 .^{5}$ Garment workers as a percent of all textlle workers do not do well. In 1970, clothing workers were 41.18 of the overall textlle industry, but earned 35.78 of its wages. In 1984, clothing workers were 42.8 of the overall textile Industry, but earned 37.28 of 1 ts wages (INEGI 1986). These flgures only measure the official gap between clothing workers' earnings and their representation in the industry. If the estimated 600,000 other garment workers were added Into these figures, the gap between employment and wages would widen conslderably.

Added to this is the Indication that garment working is one of the most important sources of income for working women in Mexico (Durand 1977; La Jornada 10/12/85). It appears that If nothing else, sheer numbers are keeping the wages of garment workers low.

One of the most important changes in the district as a result of the labor conflict after the earthquake was that 
the costureras were able to establish a place of their own for the Union's headquarters. This location is across the street from one of the most badly damaged buildings of the garment district, known as the "bullding of tombs" (Fig. 3 , site 1; Fig. 12). This is where the first confrontations between the owners, the Army and the garment workers took place (Appendix A). This space of one-half block was granted to the Union for six months, in exchange for dismantling their encampment, whlch had occupled the middle of a llujor highway for two months (Fig. 3, site 2). The Union has been using the tents from that encampment for its headquarters (F1g. 13). As of March, 1987, the Union had been in lts space for eighteen months and the owner of the propurty was requesting its return. Government bureaus involved with the garment district were supporting the owner in that request. The costureras feel that their removal from that space would be a psychologlcal blow to their movement from which they could hardly recover. They have offered to buy the property, putting up half the money if the federal government will put up the other half.

The importance of maintaining that specific place cannot be discounted as part of the power of the garment workers' movement. For the first time in Mexlco's history, there exists a physical space in the garment district for women workers, space that is controlled by women, where they 


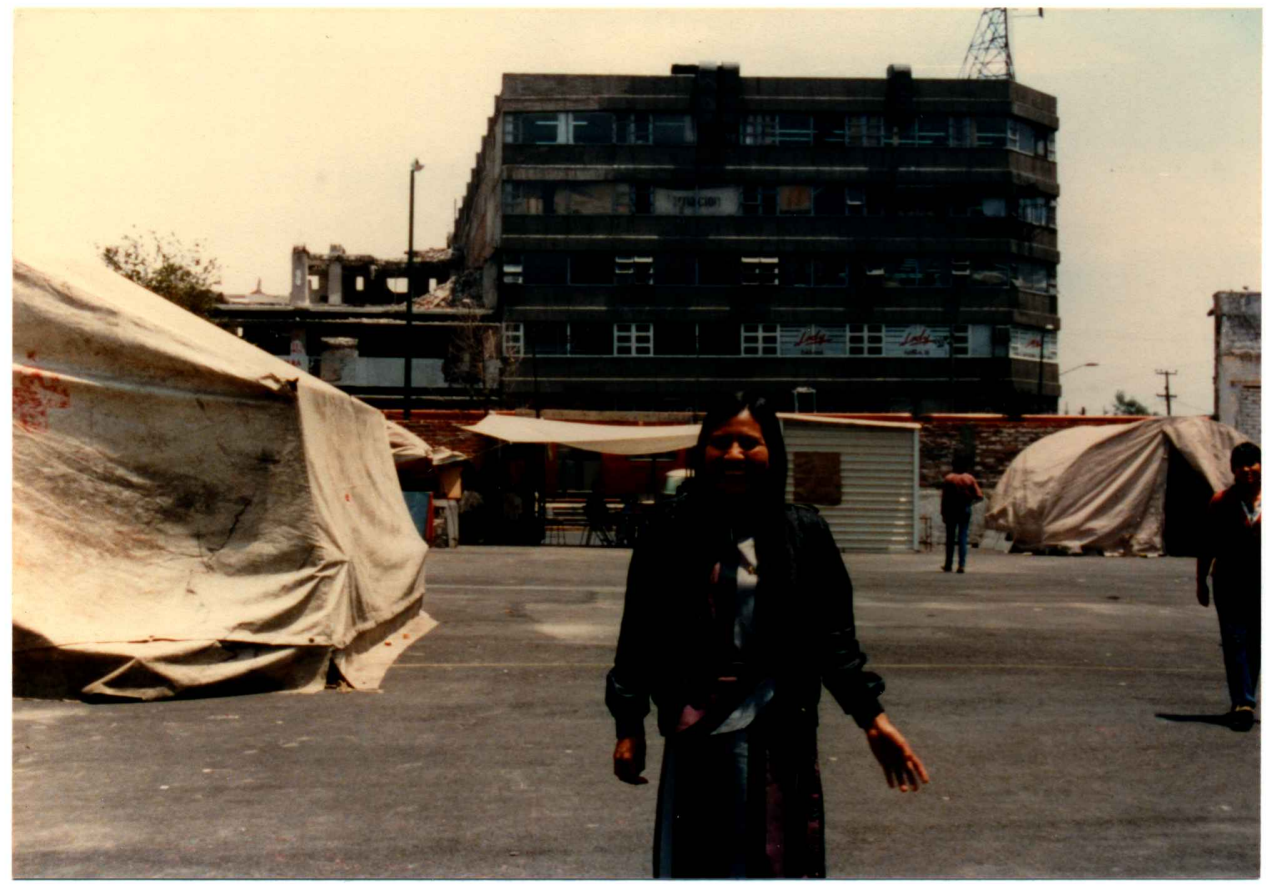

Figure 12. Union headquarters, showing "building of tombs" in background.

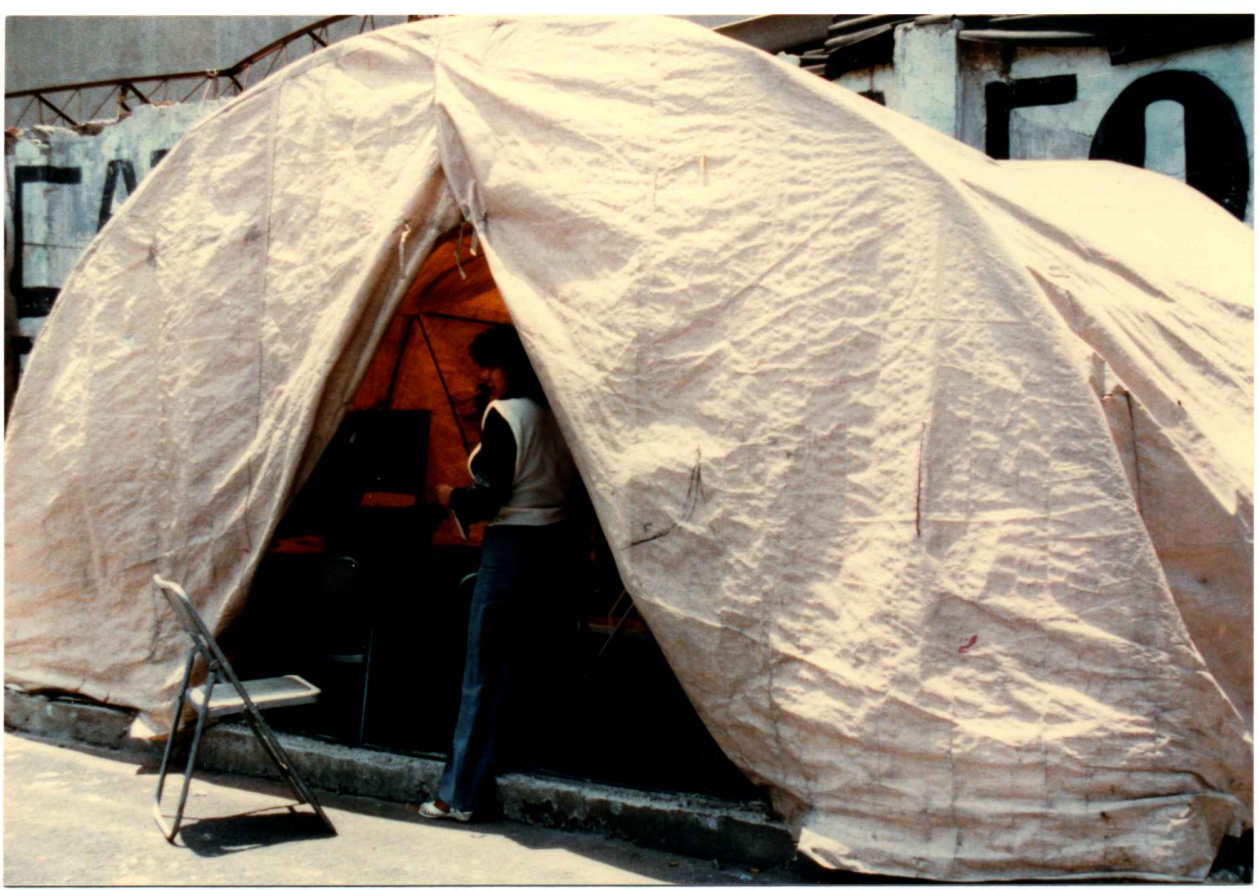

Figure 13. Tents from the encampment used for union offices. 
can meet, organize, learn, and work together. It has been vitally important for the movement that the symbols of their struggle be visible: that they are still "encamped," so to speak, in front of a bullding where hundreds of women died and where they first faced armed soldiers and where they made their first hand-painted signs. Over time, however, it has become necessary to obtain a more secure tenure in the garment district. Thus, the Union has been slowly but purposefully adding on to its physlcal "plant." "With every improvimint and every bullding project, our presence here is more secure" (International Bulletin 1987: 5). Plans are underway for primary and secondary schools for union members, a childcare center and a kitchen, all at the san Antonio Abad location. If it is successfully evicted from this place without finding a new location that is as useful and emotionally powerful as the present one, the union will have a very difficult time surviving. That fact has not been lost on the Union's subverters, and In many ways the struggle has come down to a flght over the control of a small amount of space in the center of the garment district. Under extraordinarliy difficult clrcumstances, circumstances that require a tremendous toll of energy, time and money, the Union is creating on a dally basis a physical presence, a presence that slgnifies a new social reallty in the district. The tiny toehold that the Union has carved out in 
the structure of the garment district is unique, important and fraglle. 


\section{CHAPTER III}

\section{THE WEAKENING OF A POLITICAL BARGAIN}

The conflict that erupted in the garment district of Mexico City after the earthquake must be understood in light of Mexico's fundamental political bargain between government and labor: labor will curtall its demands in exchange for economic prosperity. That bargain amounts to institutional conflict described by Edwards (1982), since there are a host of institutions and rules, written and understood, controlling labor in Mexico. Those rules in a sense "laid the ground" for the outbreak of conflict after the earthquake. Labor as a class is tightly woven Into Mexico's political system precisely to keep it powerless, and the actions of the costureras were taken within the context of that powerlessness. Their actions represent both a reinforcement of the bargain and a challenge to it. The bargain has roots in the Mexican Revolution of 1910-1917, and the accomodation between government and labor that came out of the post-Revolutionary perlod of 1920-1940. This historical accomodation permeated the dissention within the gurmenl district after the earthquake and must be explored In order to understand the effects of the earthquake. 


\section{REVOLUTIONARY ROOTS}

Mexico's Revolution was not a revolution as much as it was a civll war. It began as a middle class movement for democratic reforms and was joined by landless peasants seeking land. Thirty-five years of the dictatorship of Porfirio Diaz (the Porfirlato of 1876 to 1910 ) had radically altered the structure of economic and social relations in Mexico. The landed estates had been converted into commerclal agricultural enterprises (sometimes forclbly); the rural indigenous peoples had lost their traditional landholdings and were converted to debt peons on the commercial estates; a small middle class based on land, finance and commerce emerged; and the economy grew rapldiy under the stimulus of foreign capital. The importance of the penetration of Mexico's economy by forelgn capitalists cannot be underestimated, as nationalism was the ideology of the Revolution. By the time of the Revolution, foreign, mostly U.S., capitalists owned Mexico's rallroads, its textile milis, its steel plants, its electrlcal utilities, its oll-producing facilities, its banks, and a good deal of the commerclal agricultural sector.

A portion of the urban and liberal sectors came to articulate the basic platform of the Revolution: land reform, worker's rights, and a secular state. The unity of the Revolution, however, was stronger on the basls of what 
It was against than what it was for. The middle classes, the peasants and the urban laborers united against the military, the landowners, the bankers and the church, and eventualiy they emerged victorlous. There is no doubt that there were several gains from the Revolution written into the Constitution of 1917: universal suffrage, an end to debt bondage, land reform, an end to forelgn ownership of Mexican resources, and the most progressive labor legislation in the world of its time (Hamilton 1982).

Nevertheless, one basic contradiction emerged from the Revolution and the post-Revolutionary period (1920-1940). The Constitution of 1917 gave the state the task of protecting and furthering the revolutionary goals of the poor and the workers, while at the same time protecting the Mexican economy, 1.e., the nation's capitalists, from foreign domination. To accomplish these ends, a great deal of political power was placed in the hands of the president, and as a check, presidential terms were set for six years with no re-election. However, immediately after the Revolution, the nation was bankrupt, the state had no effective power with which to carry out its charge, the peasants were demanding that land reform be carried out immediately, the commerclal classes were withholding their investments and foreign capitalists were attempting to reassert their interests. The government moved to put down 
labor and peasant agitation, and also nationalized the formerly forelgn-owned sector of the economy, which was, in effect, all of Mexico's infrastructure. ${ }^{6}$ The state was then in the position of being on the one hand the protector of the nation's workers and the implementer of the land reform program, and on the other hand the protector of Mexico's national capitalists and the owner of the nation's major infrastructure. This infrastructure had to be operated profltably, and for the purpose of assisting the capital classes to increase their, and presumably the nation's, wealth.

In order to accomodate this basic conflict of interest, the state created, by flat, Mexico's one polltical party, the PRI (Institutional Revolutionary Party) in which the peasants and the working class were firmly entrenched, though divided from each other into separate organizations. The workers belong to the CTM, the Congress of Mexican Workers, and the peasants belong to the CNC, the National Peasant confederation. 7 The purpose of this was not to implement worker and peasant demands, though the rhetoric of the Revolution legltimized the move. The purpose was to subordinate the urban workers and rural peasants to the Interests of state and national capltal (Cockcroft 1983; Hamilton 1982; Hodges 1983; Riding 1985). 
Dominguez (1982) has described Mexico's baslc accomodation between the state, the peasants and the workers as a "soclal bargain," which has four parts. The state is the ultimate arbiter, to whlch all sectors, even those outside the official political party, have access to some degree; all sectors support the system, even if they lose in the short run, for eventually the state works to accomodate everyone, though to a greater or lesser degree. The goal of the alliance is rapid economic growth, based on industry and national capitalism. The state will distribute the wealth, In return for which labor and the poor will curtall their demands. Finally, the ldeology of the Revolution, 1.e., nationalism, economic growth, land reform, state ownership of key resources, and a secular state, permeates all public discourse and state action. Peter ward (1986) calls this bargain "inclusionary authoritarianism." The state does not hesitate to use force and repression to maintain the nation's "unity," but it prefers to act as the generous provider of benefits and favors (Ward 1986).

THE STATE AS PROTECTOR OF LABOR

The Institutional means of controling labor is the incorporation of the CTM into the PRI, and incorporation of a specifically pro-labor stance into Mexico's Constitution. Mexico has some of the most progressive labor legislation in 
the modern world. For example, when a worker is laid off, s/he is entitled to three months' severance pay plus twelve days for every year worked. Overtime is pald at twice the hourly rate, and is limited to three days per week. Soclal security is not paid by workers but by employers. Workers are entitled to two weeks' vacation pay and a Christmas bonus. Women and men are entitled to equal wages (El Dia $10 / 21 / 851$.

The reality, of course, is much different. The law weakens workers' rights by carefully dividing workers into different categorles, with different pay scales and rights according to classiflcation. Manual laborers have fewer benefits and earn substantially less than "professional" or skilled workers. Workers in cooperatives cannot strike, because in theory they own the business for which they work. Workers in the nationalized sector have limited rights to strike, because they are public employees. Workers in the massive federal bureaucracy cannot foin unlons at all, but do have an organization which is part of the PRI, and amounts to what Hodges (1983) has called the "fourth class" in the Mexican political system. There are dozens of categories of workers even within the union system: confidential employees, minor supervisory and offlce workers, permanent employees, temporary employees, etc. (Schlagheck 1980). These categorles are determined by the 
Constitution and subsequent labor law and workers are told upon hiring which union they belong to. Workers cannot chose their own union, and they cannot form company unions, or unions across broad categories of skill or employment. Further, certain social benefits are handed out by employment category. For example, starting in the 1950's, titles to land in squatter settlements were given out not by membership in a community, but by categories of employment-to teachers, rallroad workers, bureaucrats, fournalists, and electrical workers (Moreno Toscano 1982). Not all workers belong to the soclal security system (ISS) or the state housing program (INFONAVIT). Membership in CONASUPO, the federal program of food subsidies, which was meant for the poor, comes with membership in several middle class and professional unions.

Because labor is so closely woven into Mexico's political system, there are a plethora of agencles dealing specifically with labor issues within the federal government, most of which have CTM representatives within them. Among these are the National Tripartite Commission, the National Joint wage Protection Committee, the National Development and Guarantee Fund for Workers' Consumption, the National Labor Information and statistics Center, the National Institute of Labor Studies and Labor Legislation, and the National Minimum Wage Commission (Looney 1985). At 
the same time, the federal government operates labor courts, or boards of conciliation, to arbitrate disputes between management and labor. These courts are not independent adjudicators, but are made up of representatives from management, labor and the federal government. Considering the close ties between labor and the dominant political party, management and owners regard these courts as blased In favor of labor (Schlagheck 1980), and Indeed it appears that the courts are the tool that the federal government uses to promote labor rights in mexico. However, all unions must reglster their intent to strike with the court of their furisdiction, and the majority of these strikes never occur, because the court settles the lssues beforehand (Schlagheck 1980). If workers refuse to accept the arbitration decision of the court, thelr contract is terminated and management can hire replacements in their stead. If management refuses to abide by the decision, the contract is terminated and the workers are let go, although with compensation. Given the fact that there is little attempt at separation of powers in Mexico and that political pressure can be applied to Mexico's judiclal system, there is no neutral and independent adjudicator to whom parties in conflict can turn to solve problems. All labor conflicts in Mexico are solved politically, with the government playing a central role. 


\section{LABOR UNIONS IN THE GARMENT DISTRICT}

Government labor unions play an important role in the control of the labor force in the garment district by selling labor contracts, and labor peace, to shop owners in return for bribes. The tool of this system is the contrato blanco, or blank contract, which proves to be a very flexible means of controlling the workforce. The vendors of these contracts are primarily CTM labor bosses known as charros. These men have never been garment workers, which is a Job overwhelmingly done by women. Instead, they are professional labor bosses, making a career out of selling protection, 1.e., protecting the owners from legitimate organizing. They collect monthly fees from owners for keeping several blank contracts in their desk drawers covering the workers of speciflc factorles, contracts which can be filled in later if necessary. The terms of these contracts are never specified, but they are used to keep any attempts at legitimate union organizing out of the factory, as only one union is allowed per shop. Contracts are often renewed every month or three months, in order to keep workers from galning any senlorlty with a shop. Many times the costureras know nothing about their supposed membership in these unions. One costurera said, "I never met the union leader, but the owners told me to bring two plctures of myself and sald I was In a union." (La Jornada 10/26/85) 
There were an estimated 5,000 of these ephemeral contracts and contracts of protection covering the shops of the garment district of Mexico city on the day of the earthquake (La Jornada, $10 / 10 / 85$ ).

Traffic in labor contracts can be quite lucrative. According to proceso $(11 / 4 / 85)$, the bearer of the contract is the secretary-general of the union and has the ability to appoint the person who represents $\mathrm{h} / \mathrm{m}$ in the factory. Each contract holder has the abllity to call a strike, flx salary percentages, and write up worker demands. Each also has the prerogative not to do the above. The labor boss who administers the contract can earn millions of pesos, taking In as much as 2,000 pesos per month per worker, as the owners often find it easler and less expensive to pay off the labor boss than to ralse salaries to minimum wages.

The labor bosses are part and parcel of the the PRI. Hilda Anderson, the head of the women's section of the CTM, is also an official of the PRI and a representative in Congress. It is small wonder, then, that fidel Velazquez, the head of the CTM, called upon to make a show of support for the costureras after their conditions had been revealed, condemned the "monstrous colluslon" between labor leaders, government officlals, and shop owners, and fired flve CTM officials. He was right about the monstrous collusion, of whlch his organlzation was no small part, but he had no 
intention of changing the practices. When secretary of Labor Farell signed the registration for the Union, he warned the costureras that they had to compete with 500 other labor unions for contracts, putting the Union on notice that in effect, he was allowing the ephemeral contracts to continue to exist.

GOVERNMENT AND COSTURERAS IN CONFLICT

The "state" in Mexico is not the military, it is not a puppet of foreign governments and it is not identlcal with big business. The "state" in Mexico is a very strong executive, three to four million federal workers lout of a population of $80 \mathrm{million),} \mathrm{and} \mathrm{a} \mathrm{political} \mathrm{party} \mathrm{with} \mathrm{no}$ Independent powers. Because the government has deliberately fostered the Image that it is the benevolent source of all beneflts and the means by whlch Mexico's political unity is maintained, all sectors of Mexico's population look to the central government for support. This is one of the reasons that when the costureras had a conflict with the shop owners In the garment district, they marched on the presidential Palace in anger. By doing so, they implicitly reinforced Mexico's "Inclusionary authoritarianism." A truly revolutionary change would have been to have formed a union and begun strikes and negotiations without seeking registration or legitimization from the federal government. 
To have done so, however, would have been to have courted violent repression, Including the assassination of the Union's organizers (WSJ 10/4/85). Marching on the Presidential Palace did not fundmentally question the authority of the central government over labor or labor disputes; it was a rational act on the part of the costureras in light of Mexico's political system.

Another reason that the garment workers turned their labor dispute into political protest was that they did have a legltimate, specific grlevance against the government, and that was the government's role in labor unions. In this respect, their demands did represent fundamental social change in Mexico, since independent unions are rare, the last ones having been formed among automoblle Industrles which were growing rapidly during the late 1960 's and early $1970^{\prime} \mathrm{s}$ as a result of U. S. investments. Independent labor unions are a fundamental challenge to Mexico's political system, and by demanding to have an independent union, the costureras were publicly condemning the government's twosided policy toward labor: pro-labor rhetoric and ironfisted control of labor. It is not surprising, therefore, that CTM labor unlons have been as strong or stronger in fighting the Union as the shop owners have been.

As early as December, 1985, the CTM unions, in collusion with the owners, openly announced that they 
intended to "disappear" the Union (Uno Mas Uno 12/31/85). Their tactics have included threatening and attacking women as they voted, and ballot-box stuffing. They have been aided by both owners and government officials in these efforts. After warning the Union that it would have to compete with 500 other unions, secretary of Labor Farell has refused to give the Union a list of those 500 other unions, or even a list of unions at factorles with 500 or more workers (Uno Mas Uno 4/14/86). Clearly, the government recognized the basic challenge to its authority that the Union represents and acted accordingly. To the extent that the Union can maintain its status as an independent union, it represents a basic political change in Mexico. Ironically, the Union relies to a certain extent on the government to help maintain that independent status. For example, the Union is negotiating with government officials for support in stayling at its present location.

clearly, the earthquake happened within a context of complex institutional relationships that governed the dayto-day operations of the city and the garment district.

Those relationships did not change simply as a result of the earthquake, but were part of the response patterns of the people damaged by the earthquake. The earthquake was, in a sense, a new, unforeseen element in the weaving of the social web. Social evolutionary process, like natural 
evolutionary process, does not waste what has gone before, but builds on 1 t. 
CHAPTER IV

THE COSTURERAS AND THE CRISIS

The position of the garment workers after the earthquake needs to be understood in light of two dominant facts in Mexico's development. The first is the emergence of a class of working poor in Mexico, and especially Mexico city. The second is the depth of the economic crisis which the nation was suffering, and its impact on Mexico's working poor. On the day of the earthquake, Mexico was essentially bankrupt, having the second highest forelgn debt in the world, $\$ 97$ billion. Debt service was running at $\$ 10$ billion annually (about $\$ 900$ miliion per month), Inflation was running at around 50-60s a year, capltal flight was taking $\$ 3$ billion to $\$ 6$ blllion a year out of the country, unemployment was 168 by official figures (up from $8 \%$ in 1980 ), and the buying power of Mexico's 24 million workers had decreased 408 since 1982 (NYT 10/23/86). Ironically, the crisis comes after forty years of rapid economic and industrial growth. The Mexican economy has registered average annual growth rates of approximately $6 \%$ for the last forty years (Looney 1985). That growth brought fundamental social change in Mexico, creating a class of urban working poor, of whom the costureras are the epltome, and a growing 
middle class whose economic position has been extremely fragile as a result of the economic crisis. By sorting out the underlying "grid" of Mexico's economic growth since the early 1940's, it will be posslble to see that the garment workers were in a very precarious position on the day of the earthquake, a position that made them both vulnerable to the damage of the earthquake, and yet able to take advantage of the crisis to demand change.

\section{THE ECONOMIC "MIRACLE"}

In 1940 , the turmoll of the post-Revolutionary perlod had ended, Imports from Industrial countries were unavailable because World War II was in progress, and demand for Mexican raw materials by the warring nations was at an all-time high. The Mexican economy went into its "take-off" stage and has registered growth rates which have been referred to as the Mexican "mlracle" (Rlding 1985; Ward 1986). Mexico City has been the center of most of the investment, and most of the industrial, economic and population growth. The economic growth has been accomplished through rapid industrialization, neglect of agriculture, and massive demographic shifts.

\section{From Agr 1culture to Industry}

Employment and production in agriculture have declined considerably since 1940, whlle population has grown 
explosively, and employment in industry and services rose proportionately (Table III). In 1940,658 of Mexico's population was rural, Iiving in centers of less than 2,500; by $1980,65 \%$ of the population was urban (I. Scott 1982). By 1980, Mexico ranked as one of the largest and wealthlest nations of the world. It is fourteenth in size, eleventh in population, and had the fifteenth largest economy of 1980 (Rudolph 1984). Its gross domestic production of $\$ 1,546$ per capita in 1983 (Rudolph 1984) is respectable for a newly industrialized nation.

\section{TABLE III}

DEVELOPMENT OF THE ECONOMY, 1940-1980

1940

20 million

Population

Employment Agriculture Industry Services
708

158

$15 \%$
1980

72 million

Gross Domestic Product
(in 1975 pesos)
114 million
1.293 billion

- of GDP by sector Agriculture Industry Services

218

248

558
328

268

428

(Source: Looney 1985)

The engine of this economic growth was industry, which was stimulated by several federal policles. The government invested heavily in transportation and communications, 
building up an infrastructure for industrial production, almost all of it located in Mexico City. Tariffs were placed on imported consumer goods, subsidies and tax incentives were offered to Mexican businesses, and tax rates on profits were kept low in order to stimulate substitution of locally produced goods for imported consumer goods. These collective actions were the basis of Mexico's "import substitution" policy, which has been the nation's basic economic model for growth over the last forty years. As part of this model, foreign investment in Mexican corporations was kept to less than $49 \%$, although this was often subverted. Finally, federal investment in the agricultural sector was cut considerably, while federal subsidies of soclal programs, including those for schools, clinics and food subsidies, were expanded.

\section{Land Reform and the Working Poor}

over the last forty years, the rural poor have become the urban poor, who are also the reserve army of labor so necessary to Mexico's economic expansion. This process is the "proletarianization" of Mexico's population, a process whlch created a class of working poor. Land reform, which was meant to break up large estates and distribute land to peasants and which was one of the basic tenants of the Revolution, oddly enough played a crucial role in creating a 
large base of unemployed rural poor, who have been the source of Mexico's urban industrial and service workers.

First, the abolition of debt peonage created the first opportunity in hundreds of years for peasants to move off the land (Pommler 1982). Second, the land reform program was never fully implemented, and has effectively ended. Distribution of land was always dependent on the commitment of Individual administrations to the policy, and Mexico does not have an abundance of arable land in its treasury of natural resources. The large estates in the northern reglons of the nation were left alone by administrations which were ldeologically close to the large landowners, and although government investment in agriculture has decreased since 1940, that investment has been almost entirely in Irrigation of Mexico's northern regions. Seventy years after promising land reform, post-Revolutionary Mexico has a landholding pattern in which 748 of the farms hold 1.68 of the farmed area whlle 78 of the holdings over 100 hectares hold 958 of the farmed area (Looney 1985). The promise of land reform, still part of the soclal bargain of Mexico, turned out to be an empty promise.

Under the Cardenas administration of the 1930's, which was more committed to land reform than any other administration, rural peasants were not glven full title to their land, but held it communally, based on the traditional 
Indian communal landholding patterns. These efidos were intended to protect peasants from exploitation, since the land was never to be sold or divided. As a further "protection," the efidal organizations were tied into the PRI, through the peasant organizations. The reality of this form of land distribution, however, meant that land owned previously by private owners stayed in private hands (if it Wal: not confiscated for land reform), but land turned over to peasants could never be individualiy held. At the same time, within Mexico city, the Cardenas administration developed a pollcy of legalizing titles to property held by squatters, a policy which was later expanded by other administrations. A rural peasant was more likely eventually to own his or her own plece of land in the city of Mexico City than s/he ever would in the rural areas (Moreno Toscano 1982). These factors provided the "push" from the land, and jobs and soclal benefits withln the cities, especlally Moxico city, became the "pul1."

The Working Poor and the "Miracle"

By 1980 , only 308 of the population of Mexico City owned land (Moreno Toscano 1982). In 1982, in the Mexico City metropolitan area, 408 of the population recelved no health care, 518 were without running water in their homes, 22.68 were unable to satisfy their basic needs, and some 800,000 families $(3,000,000$ people) were without housing 
(Riding 1985). Residents of the metropolitan area, however, are better off by most social indicators than most of the rest of the country (Ward 1986).

Further, there is a wide gap between the earnings of the rich and the poor, and that gap has been widening during the years of the "miracle." In 1950, the wealthiest 58 of the population had an income 22 times larger than the poorest 108 of the population; in 1977, it was 47 times greater (Rudolph 1984). In 1977, the wealthlest 108 of the population received $38 \%$ of the national income, while the poorest 108 earned 18 of the nation's income (Rudolph 1984). The structure of investment helps to explain the uneven distribution of income in Mexico's economy. Generally, the greatest investment, and the greatest income, has been in a very small segment of the economy--the modern, highly technological sectors, which are capital intensive and extremely productive, but do not absorb much labor. An analysis of the 1965 survey of industry found that overall, 848 of the firms accounted for only 1.98 of invested capital and 3.98 of production while at the same time 5.78 of the flrms accounted for 928 of Invested capltal and 88.58 of production (Alonso 1983). This means that the vast majority of Mexico's businesses are small, undercapitalized and not very productive. This gap has often been described as the difference between the "artisan" sector and the modern or 
technological or "dynamic" sector (Alonso 1983; Deross1 1970; Durand 1977).

This pattern holds as true for the garment industry as It does for all Industry in Mexico. For example, in 1965, garment factories made up 13.68 of industrial plants but only 2.58 of Investment and 3.68 of gross production (Derossi 1970). At the same time, 878 of garment factories employed less than five people, and another $10 \%$ employed six to fifty people (Deross1 1970).

The "dual economy" helps to explain why the industrial sector of the economy has not absorbed its share of labor (Table III). The decrease in agrlcultural employment has been counterweighed by a greater increase in employment in services than in industry. Superiority in productivity of modern industrial methods has been accomplished through machinery and capital investment. Though millions of people moved to the city in search of industrial jobs, the promised Jobs have not been forthcoming as fast as have the Jobseekers. In 1983, the government of Mexico admitted to an offlclal figure of 138 unemployed, but 408 "underemployed" (Rudolph 1984). More telling, however, is the fact that 498 of the working population of Mexico city earns less than minimum wages (Riding 1985). 
The Development of the Cris is

The structural weaknesses of Mexico's economy have been well identified by analysts (Looney 1985; Riding 1985; schlagheck 1980). First, the government did not finance its social programs and its infrastructure provision through tax revenues or by operating its share of the economy profitably. It financed its spending through borrowing abroad. Second, the tariff protections local capital enfoyed made Mexican Industry weak and non-competitive. Third, Mexican business has had to finance its growth through borrowing abroad, and importing capital equipment and technology. Thus, the import substitution policy had the long-term effect of making Mexican capital more dependent on imports (Looney 1985). Finally, much of Mexico's wealth has been plundered by bureaucrats and wealthy elites and sequestered abroad (Eckstein 1977; Henry 1986; Riding 1985).

By 1977 the strains of too much growth, too much spending, too much debt and too much capital drain were seriously affecting the Mexican economy. In that year, the peso was devalued and the government began an austerity program in exchange for an IMF loan. In that same year, however, Mexico began to sell its recently discovered vast reserves of oil, and quickly became the fourth largest producer of oll in the world (Rudolph 1984). Export 
earnings rose from $\$ 6$ billion in 1977 to $\$ 19$ billion in 1982, 758 of which was from the sale of oll (Hamilton 1984). At the same time, spending on Imports rose from $\$ 6$ blilion In 1977 to $\$ 23$ billion in 1981 (Hamilton 1984). Much of that Import was of capltal equipment to develop the oll industry. On the basis of projected growth rates of 8-98 unt 11 the end of the century, the government took on a program of extensive borrowing; forelgn debt rose from \$34 blllion in 1978 to $\$ 51$ bllition in 1980 to $\$ 88$ blllion in 1982 , 258 of which was for PEMEX, the national o11 company (ECLA 1985; Hamilton 1984). Corruption, mlsmanagement and capital flight reached epic proportions, while the austerity measures of the IMF were quietly swept aslde (RIding 1985). In 1981 when the price of oll suddenly dropped, Mexico was not in a position to weather the contraction. By 1982, inflation was running at 1008 , and capital flight was rampant. From January to March of 1982, $\$ 8$ blllion left the country (Hamliton 1984). President Lopez Port1llo devalued the peso early in 1982 and just before he left office, in August of 1982, he nationalized the banks in order to halt the capital drain.

011 prices have remained sluggish and Mexico has not been able to recover from the events of 1982 whlch have collectively come to be known as La Crisis. Emergency loans from the IMF have helped tide the economy over, and the 
government of president de la Madrid has held the nation to an austerity program that included cuts in soclal programs and price rises for basic foodstuffs. Nevertheless, on the day of the earthquake, the IMF announced that Mexico was out of compliance with the austerity program and cancelled the final instaliment of a three-year, $\$ 3$ blllion loan.

THE POSITION OF THE COSTURERAS IN THE GARMENT DISTRICT

In light of Mexico's development and its current economic crisis, the costureras were in a position of almost complete powerlessness in the garment district. They were subordinated to government labor unlons, they were subordinate to owners, they were hemmed in by inflation, unemployment and Mexico's skewed distribution of income, and they were exploited also as women.

The Costureras as a special Case of the Working Poor

One of the primary characteristics of the garment Industry is its reliance on female labor. The industry has traditionally relled on female labor precisely because of its need to hire and fire on short notice. Women's unpaid and privatized labor in the domestic sphere of production is deemed to have no economlc value; they lack access to education and other resources; their position as mothers makes them economically vulnerable when there are very young dependents to take care of, and their competition on the 
labor market has been hampered by deliberate discrimination. Thus, women make a perfect reserve army of labor to be called up and disbanded when the industry needs them. Several decades of urbanward migration, the emergence of a class of urban working poor and the advent of La Crisis meant that there was a large pool of exploitable female labor in Mexico city. The costureras represented the epitome of Mexico's class of working poor, and took the fobs that they did because they had little cholce.

The majority of the costureras are young. A study by the Ibero-American UnIversity, reported In El DIa $(10 / 21 / 85)$, found that 798 of the costureras were between the auges of 19 and 30 , though the costureras reported that 1t was becoming increasingly difficult for workers over 25 to obtain work. The most common age for entry into the factories is 18 to 20 , though a few reported that they did not start until they were in their early twenties and one reported that she started at 15 (Costurera Group Interview 1986). The costureras reported in private interviews that they thought some of the victims of the earthquake were as young as 13, though they were not sure because not everyone knew who was killed, not all the bodies were recovered, and some young girls added to their age in order to get work. The Ibero-Amerlcan University study also found that 488 of the costureras had not finished primary school. A 
primary education is one of the job requirements often placed on costureras in the more modern factories. This distinction, which is not necessary for a repetitive standardized job, leaves many women at a greater disadvantage than their skill level would warrant. The majority of costureras are elther single or in relationships that do not constitute marriage: widowed, divorced, in free union (Durand 1977). For all age categorles, the proportion of married costureras is between 8 and 9 percent (Durand 1977). The Ibero-American University survey found that 668 of the costureras were single mothers (El Dia 10/21/85).

It appears that the majorlty of the costureras were born outside of Mexico City and currently live in municipalities surrounding Mexico city. This point may be so commonly understood that its relevance was overlooked by the several researchers who interviewed the costureras after the earthquake. The fact that transportation subsidies and shorter work days to account for the journey to work became part of the demands of the Union, however, indicates that the majority of the workers were residents of the city's many surrounding municipalities and squatter settlements. The story of Evangelina Corona, the General secretary of the Union, is representative of the costureras. She was born in Tlaxcala (Fig. 1) and moved to Mexico city at the 
age of fifteen in order to earn money to send to her famlly. After working several jobs as a domestic servant, she began to work in the clothing factorles, and on the day of the earthquake had worked in them for 22 years. She never married but has two daughters, one of whom is marrled and one of whom is finishing high school (Proceso 11/25/85). Ms. Corona's story is paralleled by hundreds of other similar stories. Though further research needs to be done, it appears that the garment factorles are drawing on a defined pool of workers preclsely because they find that in their constrained positions as young women with little education, with children to support alone, recently arrived In the clty, and intensely poor, these women have little chuice but to take what work, poorly pald and exploitive as it is, that they can find.

Inu. ied and Overt conflict in the Factories

The position of the costureras in relation to shop owners was one of almost total powerlessness. Not only did they earn low wages for work days of ten to twelve hours, but there were daily abuses and indignities. Some owners docked workers' pay one hour for every minute a worker was late to arrive to work. Once a manager made a woman walk in a small circle for an entire workday for belng late to work (La Jornada 11/30/85). Bathroom privileges were restricted. Women had to clean the bathrooms themselves, on their own 
time. Lunch hours ran from non-existent to half an hour. Hirings and firings were arbitrary and discrimlnatory; pay per piece and production quotas were set entirely by management. Women could be moved on or off a machlne without notice, which caused workers who had attained high speeds to start over again on unfamillar machines. Workers could not recelve or make telephone calls, and therefore were out of contact with their children for up to elghteen hours in a day. The workers could not call the factory to report they were slck, but had to go to the factory to ask for permission to take a sick day. The fob was also hard on the health of the workers. Arthritis, blindness and kidney disease were common. The most dramatic statement of this problem was reported by Durand (1977). The Levi-strauss factory (a large factory, now closed because of the economlc crisis) awarded the title of "Miss Levis" to the most productive workers of the week, and then used her production to set the minimum quota for other workers to attain. However, the winners of the "Miss Levis" title regularly die early, blind and with kidney disease.

In spite of the obvious odds against them, individual women over the years had made attempts at organizing against these conditions. La Jornada $(11 / 25 / 85)$ reported on a study done at the National Autonomous University of Mexico (UNAM) regarding organlzing attempts by costureras between 1980 and 
1985. The report stated that during this time, 43

complaints were flied with the government against 37 garment factories. In addition, the report found that in at least seven of the factories affected by the earthquake, the workers had already begun to organlze. In one factory, workers struggled for and won the right to have fifteen minutes to eat lunch and have five minutes added to the five minutes per day they were allowed to use the bathroom (Guerrera Interview 1987 ).

The response of the owners to worker organizing was usually Immedlate and harsh. Lupe Conde, who worked 20 years in 90 factories because, as she said, she kept trying to quit, reported that she was blacklisted for several years by shops in the central alstrict for attempting to organize the workers at her shop. As a result she had to take jobs in the tiny shops in the municipalities (Lovera 1986). These attempts at organizing in the garment district before the earthquake show that the implicit conflict of interest between workers and shop owners was recognized enough to erupt on its own, though erratically, into overt conflict. However, most of the women, by their own admission, were strapped in by dally concerns of taking care of their familles and surviving In Mexico's inflationary climate. The array of powers against them appeared too overwhelming for them to demand change, or even envision change. st111, 
one could argue, as the costureras do, that conditions were changing in the garment district and workers were beginning to organize, though at a glacial pace. The perception of the costureras is that the earthquake speeded up and intensified a pre-existing process of change (Guerrera Interview 1987).

THE COSTURERAS RESPOND TO THE CRISIS

The most salient feature of the garment workers' response to the emergency created by the earthquake is that it changed over time. In a sense, there was not one response but several, as conditions changed. Their initial response was one of attempting to rescue, recover and restore, as social science theory predicts, but because of the complexity of relations in the garment district, their actions toward rescue and restoration brought them into direct conflict with their government and their bosses, and into a realization of the weakness of their position in the district. Their status as Mexico's working poor in a nation that was bankrupt meant that they were economically very vulnerable to the loss of their jobs. On the other hand, once the walls came down and they had lost their livelihoods anyway, there was little to restrain them from protest. As one woman said in a personal interview, "We were already out on the streets. What more could they do to us?" (Costurera 
Group Interview 1986). Ironically, much of what the costureras demanded was to be made part of the system of protection and benefits from which they had been so thoroughly excluded.

on the day of the earthquake, some of the factories had started working and some had not. Many people were still out on the streets on their way to work when the earthquake struck. The Immediate events surrounding the earthquake and the first hours and days after it are probably lost to academic scrutiny. of the four dally journals that kept the garment district labor struggle allve In the media for several months, the first to report on the events was La Jornada on September 28,1985 , nine days after the earthquake. The other three did not report on the events until october 4 or later.

Conflicts broke out over two types of responses: those In which owners took out their machinery and materials and either disappeared or relocated, leaving workers fired, abandoned, or "on vacation", and those in which owners or managers forced workers to continue or resume working in damaged and unsafe bulldings (Append $I X A)$.

Responses by the costurereas took two forms. One was confrontation with owners, with the soldiers, with government officials. Machinery was seized by workers, and rescue work was carrled out by familles and friends, in open 
violation of the orders of the military authorities. The other response was to form cooperatives in order to continue work. Several of these were announced in the newspapers, but only three apparently started within a short time of the earthquake. As of March 1987, there were eight operating cooperatives which grew out of the foblessness left by the earthquake, at least one of which, for older workers, is under the direct organization of the Union (Carrillo Interview 1987). However, since the National clothing Chamber (a government-mandated trade organization) estimates that there were 40,000 workers left without jobs (using, apparently, a formula of 800 shops destroyed and 50 workers per shopl, these eight cooperatives have not been the means by which workers have successfully responded to the earthquake.

Public attention to these events was aroused through the media, primarily through the work of feminist journalists. These writers did not just report the events, but actively particlpated in the conflicts. Elena Poniatowska, a well-known feminist and political writer, was at Dimension Weld (Fig. 3, site 1; Appendix A), when the owner, Elias serur, attempted to take his machinery out of the building. Tensions were mounting, as privately hired machine operators used their heavy equipment to take out machinery from the factory, soldiers attempted to keep the 
costureras away from the bullding, in which dozens of women were still trapped, and the costureras and their supporters bullt a barricade with debris from the fallen bulldings in order to halt the trucks which carrled the rescued materlals. Ms. Ponlatowska crossed Into the restrlcted area, found Mr. serur and attempted to interview him. She pressed him until he sald he would pay the workers for the days they had worked, but at the same time made threats agalnst thelr safety if they continued the 1 r barricade. that time, tensions were too high to be stopped and the "Incident" quickly escalated into the first full confrontation between the military and the costureras, and is now generally counted as the beginning of the movement in the San Antonlo Abad area (Lamas 1986).

with the sudden attention of most of Mexico's public media on their struggles, the costureras quickly gathered support. Actlve public support came from four main sources. other labor organizations, such as the union workers as the Pascual bottling plant, collected food and clothing needed by workers while they were engaged in pressing their claims from the government and owners (E1g. 3, sites 5, 11; Appendix $A)$. Feminist organizations, including the LesbianFeminist Marxist-Leninlst study Group from the National University, and the Feminist solidarity Committee, took supplies to costureras and cooked for them and did chlldcare 
while the women marched, held machinery, and engaged in negotiations. The National Front of Democratic Lawyers offered legal assistance during the first few weeks of the conflicts. Members of the Revolutionary Workers' Party helped organlze and support a camp of famlly members of costureras who had been killed.

In early october, the efforts of the costureras, their supporters and familles, changed from rescue of bodies, and spontaneous conflicts with authorities, to organizing. On October 2, the La Promotora de Costureras Damnificadas (organizing Committee of the Garment Workers Affected by the Earthquake) was formed. On october 9, La Union de Costureras en Lucha (Union of Costureras in struggle) was formed by the costureras in the san Antonio Abad region. On October 13, La Organizacion de Costureras del Centro (Organization of costureras from the Center) was formed (Appendix $B$ ). After a dramatic all-night meeting, these two unions joined forces, and the next day, October 18, they marched jointly to the presidential palace to present their petition to the president and the secretary of Labor. More than a thousand workers from 26 factories marched on the Presidential palace, and had to sit in at the offices of the secretary of Labor almost all day before they got what they wanted: a recognized, independent union, and a promise of government assistance in the indemnification proceedings. 
They did not get something of utmost importance to their struggle--the right to bargain for contracts with the owners on a company-wide basis, but had to agree to flght for contracts shop by shop. This, and secretary Farell's Indlcation that he still considered the thousands of paper contracts in the garment shops valid, was a setback from the very beginning.

The next several months were spent primar1ly on two major activitles: building the unlon by afflilating new members and winning contracts in factorles, and negotiation with the government and the National clothing Chamber for indemnification for workers who had lost their jobs or their lives in the earthquake.

In February of 1987, it seemed clear to this writer that the Union is involved in a new stage, that of organizing for a long-term struggle. Since the first twelve contracts were signed with owners within the first year after the earthquake, no new ones have been signed, though fifteen are beling negotlated. Several owners have closed down their factories and moved after signing the contracts. Robert's, a very large factory which was not damaged by the earthquake but whose 700 workers were the first to affiliate after the earthquake, has flled a lawsult against the Union, claiming that it was 11 legally registered. That lawsult was 
flled on May 10, 1986 and has taken much of the Union's attention.

Further, the Union has been unable to extend its organizing efforts to other parts of the nation. One of the first acts of solidarity with the Union occurred when the Authentic Workers Front, a union of garment workers in Irapuato (Fig. 1), affiliated with the Union. This allowed the Union to qualify as a national union, which it needed for government recognition. Workers in Veracruz (Fig. 1) then attempted to affiliate with the Union, but when 75 fired costureras had a sit-down demonstration at the factory, they were beaten up by 150 armed men hired by CTM labor bosses. The Union was unable to send help and the effort in Veracruz has collapsed. Lack of time and money mean that the Union has to focus its efforts in Mexico city. The Union has sought international support, and it has been successful to a certain extent. By June of 1986, the Feminist solidarity Committee had collected $\$ 22,000$ for support of the costureras, which came from the U.S., Japan, France, England, Martinlque, Venezuela and Canada (Ĺa Jornada $6 / 27 / 86)$. The Union held its first international exchange in October of 1986, by inviting supporters from the U.S. to meet with the Union. Union members traveled to Detrolt for a labor conference in 1986 and members of the Union met with garment workers from the Phllippines in 
October of 1986 during a labor conference in Manila. In February of 1987, the union sent a traveling display with their history in pictures on a tour of the United states. In addition, the costureras have focused on taking care of their own ongoing needs. They bought a house, a few blocks from Union headquarters, to provide daycare, and enrolled over one hundred children. They have also started a school to raise their literacy levels and to teach themselves political organizing skills. These organizing activities have had to operate in a climate of much less public attention and support than they had during the crisis period, an Increasing economic crisis which is forcing people back into low-wage Jobs, and mounting resistance from owners and government unions.

The long-term battle has yet to be won. For that reason, the costureras are beginning to downplay the importance of the earthquake and to concentrate on getting support for their struggle against exploitive conditions of work. Though the earthquake was tragic, they do not want to be supported on the basis of that alone. The real crime, in their analysis, is continuing exploitation in the garment factorles, earthquake or no earthquake. This battle is more subtle and is therefore harder to win support for, because it is not a dramatic headline-making event. In the minds of the costureras, however, it is the real struggle. 


\section{CHAPTER V}

\section{CONELICT IN THE GARMENT INDUSTRY}

The costureras were not the only people in a precarious position on the day of the earthquake. Both the owners and the government were in difficult straits. In 1985, 258 of Mexico's garment factorles went bankrupt (Perez Sanroman 1986). Most of these fallures cannot be ascribed to the earthquake, but to La Crisis, which hurt the garment industry as much as the rest of the economy. Once again, the earthquake had a two-sided effect. On the one hand, it hurt businesses already squeezed from several sides, but on the other it gave them an opportunity to make changes that they perhaps might not otherwise have made. The government was caught wearling many hats, whlch brought it into conflict not only with the owners and the garment workers, but internally, as various government agencles had different agendas to promote. In order to understand why the owners and the government responded to the earthquake in the way that they did, it is necessary to analyze the underlying network of the development of Mexico's garment industry. 


\section{THE GARMENT INDUSTRY IN CRISIS}

Direct forelgn investment in Mexico's apparel Industry is only about 8 of total investment. However, because foreign investment is concentrated in the modern sector that produces for the lucrative export market, national capital produces for the internal market, which is very sensitive to the state of the national economy. Under pressure from a weak Internal economy and investment from abroad, natlonal capitalists are left with the cholce of elther Investing in modern technology and attempting to compete for the export market, or breaking down their production into ever smaller subcontracting units, in order to cut costs. The cholce, for the most part, has been the latter. Alonso argues that it is the investment of foreign capital in Mexico's apparel Industry that causes the "uncontrolled appearance of thousands of domestic seamstresses in metropolitan Mexico City" (Alonso 1983: 162). The affects of the economlc crisis have done the same.

Even by officlal figures, the textlle Industry overall was hurt by the advent of La Crisis. Inflation hurt the industry badly. In 1982, clothing had an inflation rate of over 628, and in 1983, clothing suffered a whopping 1108 inflation rate (INEGI 1986). This inflation caused an immedlate decline in orders. CANAINTEX (National Textlle Industry Chamber) reported that orders were down 248 in 1983 
in the textile Industry (Expansion 1984). By 1985, approximately 408 of Mexico's textile capacity was Idle (Saenger 1986). These figures do not state whether they Include clothing as well as fibers and fabrics, but the clothing industry was hurt as well. The $25 \%$ of Mexico's garment manufacturers that went bankrupt in 1985 cannot be accounted for by the earthquake. of the National Clothing Chamber's 3,200 registered members, 1,300 were damaged or destroyed, and of these, between 500 and 800 were totally destroyed (Perez Sanroman 1986). Saenger (1986) reports that only 200 garment industries in Mexico city were totally destroyed by the earthquake and of these, 808 had reopened within a few weeks, the majority outside the city center. This is substantlated by newspaper accounts (La Jornada $10 / 10 / 85,10 / 16 / 85)$. It would appear that the earthquake can account for only a small portion of the industry's hard times. The U.S. Embassy report (Perez Sanroman 1986) lists the irregular supply of fabrics and other consumables, the increasing cost of raw materials, lack of financing, and static domestic demand as factors in exacerbating the clothing industry's difficult situation. It would appear that the clothing industry, never on particularly safe ground, was in an especially difficult position on the day of the earthquake. 


\section{THE NATION'S CAPITALISTS}

The owners of the garment shops are the least known element of the conflict, and this writer was unable to find any studies of the owners of Mexico's garment factories, either in Mexico city or nationally. One of the main agenda items of the Union is to find out more about who owns the shops and how they are tied financially to other businesses, Inside and outside Mexico.

Mexico's capitalists are generally referred to as a monolithic group. It appears that there is only one booklength study of Mexico's entrepreneurs available, and that Is Derossi's The Mexican Entrepreneur (1970). She studied over 200 Mexican business and industry owners and managers, deliberately selecting firms that are larger, better capitalized and more technology-based, rather than from the 848 of the firms which are part of the "artisan" class. She chose to study this sector of the capitalist class because she felt that the potential for Mexico's economic growth lay within 1t. This focus provides a skewed vision of the nation's capitalists for the purposes of this paper. However, the work presents some findings which may be of use in looking at the owners of garment shops.

First, most businesses are famlly run and owned, and the smaller, older and more traditional they are, the more likely they are to be completely or almost completely famlly 
dominated. As firms get blgger, or move into more modern sciluri of lhe economy, family ties are less important, but still account for much of the interchange among boards of directors, sources of finance, etc. This family orlentation can be seen in at least two of the events following the earthquake: Shops at sites 15,16 and 17 were owned by brothers who moved their equipment to shops that they owned in Toluca, a city in the state of Mexico (Fig. 3; Appendix A). The owner of the shop at site 3 moved his equipment to his brother's shop (F1g. 3; Append1x A). These actions indicate that there is an underlying network of relationshlps among shop owners that needs research.

Second, most entrepreneurs are elther forelgn-born or first-generation immigrants. There seems to be a difference between those of spanish orlgin and those of "other" origin. The spanish are concentrated in older, more traditional industrles, such as food, wine and textiles. Having been in the country longer, they tend to be secure in their positions and not willing to branch into electronics or other more modern Industries. The "other" tend to be refugees from Europe and the Middle East, who bring with them a very different range of skills. These immigrants tend to go into the professions first, commerce second and Industry last, but when they do invest, they, like Mexican entrepreneurs, chose the more modern sector of the economy. 
It appears from newspaper accounts that the majority of garment shop owners are Mexican, Jewish or Arabic, mainly Lebanese. This would indicate that a substantial proportion of owners are immigrants or are from families of immigrants, who most likely go into the garment industry because it is relatively cheap and easy to enter and leave. This would indicate that garment shop owners are from a poorer class of immigrants than those researched by Deross 1 (1970). In addition, the anti-semitic overtones of some of the protests by the costureras would indicate that many of the owners are recent immigrants. Ironically, one of the bitterest labor struggles reported in La Jornada took place in one of the municipalities and was not part of the events of the earthquake. That struggle had been going on for two years on the day of the earthquake and the owner was Lebanese. None of the costureras' comments referred to his national origin. In addition, some of the costureras admitted that Mexican owners were as exploitive as immigrant owners. Nevertheless, one of the undercurrents of the conflict was anti-semitism on the part of the garment workers towards Jewish owners.

Third, practically none of the entrepreneurs come from working class backgrounds (88). Positions in the family business tend to be inherited, and the education of the children focuses from their earliest years on training for 
take over of the business. Landowners dispossessed by land reform make a significant source of capitalists, though not all moved directly into industry. Of the chlidren of the former landowning classes, about 258 went into professions, 258 into industry and 508 into agriculture, but the grandchildren of the landowners had invested predominantly in industry.

\section{STATE-CAPITAL RELATIONS}

There has been much discussion in the literature about the exact nature of Mexico's political bureaucracy and its relationshlp to capital. Hodges (1983) likens Mexico to the Bonapartist state, in which political and economic power are split, meaning that there are two ruling classes, not one. Smith (1977, 1979) finds that the federal bureaucracy is its own class, separate from business and not particularly loyal to 1t, capable of acting on behalf of forelgn capital or labor on occasion. He finds that instead, the system is made up of "technocrats," who are more interested in their own political careers than in managing the nation or representing sectors of the populace. Hamilton (1982), while acknowledging that it is not identical with capital, finds that the federal government's power is severely limited by the logic of the model of development that the nation embarked upon in the early part of this century. 
The entrepreneurs of Mexico do not have an Identity with the government, as almost none of their children go Into government and almost none of them have parents who were in government (Derossi 1970). There is, however, a dependence on government in the form of subsidies, licenses, financing, etc. Further, the government regularly increases or contracts its share of the domestic economy, which means that, In a sense, no Mexican enterprise is entirely free from the threat of nationalization. On top of this, the government requires that all industrial sectors have national chambers, or trade organizations, to which membership is required and assigned by the government. votes within these chambers are welghted by size of flrm, which of course gives the larger flrms the greater volce. Derossi divides capital-government relationships into three types. The center-dependent are those businesses which operate near Mexico City and are heavily dependent on government policy for their survival. The peripheraldependent operate far enough outside of Mexico city, in the states immediately surrounding the Federal District, to be out of the malnstream of contacts and benefits, but not far enough out to be free of government interference. The peripheral-independent are concentrated in northern Mexico, far enough away to be relatively free from government scrutiny and which have developed their own networks of 
information and finance. The flrst two relationshlps are much too dependent on the government to be able to challenge 1t, though the bargaining position of those businesses in the center is stronger than those of the immediate periphery. It is the industrialists of northern Mexico who can afford to challenge the government's central authority, and not surprisingly, they form the base of the National Action Party (PAN), Mexico's rightist opposition party. None of the entrepreneurs of Derossl's study (1970) expressed the opinion that labor unions were an important factor in their daliy operations or their future plans. Labor, in their opinion, was entirely a creation of government. They expressed the opinion that where there was labor trouble, the source was either an individual attempting to gain personal power, or the government attempting to put pressure in some way on their operations. The entrepreneurs saw themselves as an extremely important part of Mexican soclety, the source of its economic growth, and did not see labor as a counterweight to their power. "... [T] The only countervailing power to business in Mexico is represented by the government, not by labor unlons" (Derossi 1970: 179). Thus, though every industrial worker in Mexico is covered at least nominally by a labor contract, the labor unions are not seen by the entrepreneurs as institutions with independent power. They see unions as extensions of 
government power and policy, whlch for the most part favor their enterprises, rather than working against them. The fact that most of the garment businesses are unregistered, and therefore 1llegal, sheds some light on the complex relationship between capital and labor in Mexico. In the first place, 958 of Mexico's small garment shops are razones soclales, or unlncorporated businesses owned as personal property of the manufacturer (La Jornada 10/3/85). A producer wlll often have several of these razones soclales in his name. If the pressure comes down on one shop, from labor or from government inspectors, the owner often closes it down and shifts operations to one of several others he operates under his name (La Jornada 10/21/85). Owners also avoid paying taxes by keeping their shops personal and unregistered. However, they could not do this wihout the direct complicity of government agencles, specifically the labor unions, and regulatory agencies, which either ignore the shops, or are part and parcel of their operation. Thus it is apparent that the government and the owners, while colluding in the creation of the garment district, did not have identical interests on the day of the earthquake, and thus had to respond differently to it. 
THE OUTBREAK OF CONFLICT

Because of the loglc of capitallsm and the extremely uncertain economic situation on the day of the earthquake, It became clear to all concerned that the means of production--the machinery, the materials, and the strongboxes that contained the money--were more valuable to the owners than the workers. The owners thus rescued and attempted to restore their previous situation, but according to the logic of their interests. In fact, the owners found themselves in the position of being able to take advantage of. the havoc of the earthquake to make production changes. The National Clothing Chamber recommended that its members "suspend" all activities for three months, taking advantage of the earthquake to make much-needed technological changes or to relocate. The first to apply this advice was Confecciones Yanet (Fig. 3, Site 12; Appendix A), even though the factory suffered no damage, and 21 workers were lefl wilh no salarles and no severance pay (La Jornada 10/4/85). The owners may have been eager to take the advice because, as the U.S. Embassy report suggested, "the earthquake created an opportunity for the Industry to renovate its productive plant and become more competitive." (Perez Sanroman 1986: 3). They may also have been eager to take the advice because the chamber's attorneys suggested that the applicable federal laws concerning pay and benefits 
would be "in exception" as a result of the suspension. Businesses that were not damaged by the earthquake took advantage of the fact that they operated within the zone of damage.

Although the owners did not call out the Army, they used it to protect their interests. In some cases, the owners paid soldiers 2,000 pesos for each bolt of cloth that they rescued (Informacion obrera 1985). In addition, the Army, under the guise of maintaining public order after the earthquake, soon came to protect the property of the owners. The newspaper accounts of the earthquake reported that there was very little looting throughout the city, and public crlticlsm soon focused on the fact that the Army unlts should have been helping with the rescue work, rather than pointing their guns at the citizenry. Within a few days, the role of the Army did shift, but in the meantime, the whole rationale of its job was to protect private property from theft. Its actions within the garment district were a direct result of this discharge of duty, and helped to escalate a tense situation into political protest.

The response of the government was contradictory.

Proceso $(10 / 21 / 85)$ pointed out the absurdity of the embarrassed finger-pointing by government officials in response to the revelations brought on by the earthquake. Fidel velazquez, the head of the CTM, blamed the conditions 
In the district on one labor director and said there were no federal authoritles to be blamed for the conditions. He claimed that he did not know of the conditions of the factories because all of his clothes were made at home. The CTM leader for the Federal District blamed the federal authorities (the courts and the inspectors) and clalmed that there were no labor leaders who sold union contracts. One senator blamed Rep. Hilda Anderson, who was also head of the women's section of the CTM. Hilda Anderson claimed that she had always attempted to help the costureras, but they had no education, no political ablilties, no organization. Antonio Burelo, the head of the offlce of Conciliation and Arbitrage (the labor court system) blamed the labor unions. He was fired a week later for complicity with owners. Arsenio Farell, the nation's secretary of Labor, said that now that the conditions in which the costureras worked had been brought to light, his office would seek to protect the costureras, and naturally this protection would be through labor unions and union contracts.

Federal authorities were not all words, elther. The federal government set up an offlce of Concillation and Arbitrage at the 150-164 San Antonio Abad location (Fig. 3, Site 1) (La Jornada 10/9/85) because the local offlce was not functioning. Hilda Anderson toured the area and met with costureras, who did not recelve her kindly. Programs 
for women and youth offered assistance to workers who wanted to set up cooperatives. After inspection by governmentprovided experts, some of the bulldings were closed by federal authorlty as unsafe. Heavy machinery was finally provided to the rescue workers for the garment district, but not until four weeks after the disaster, too late to save anyone. The House of Representatives appointed a committee to research conditions in the district. Five CTM officials were flred for selling labor contracts. Presldent de la Madrid met with the costureras, and ordered the secretary of Labor to grant them the registration of the union that they sought. Last but probably most important in its long-term impact, the government began a program of loans to garment shop owners for relocation out of the area.

Hispanoamerlcano (1986) reported slx months after the earthquake that the federal government was offering loans of several million pesos to "mlcrobusinesses" in the garment district to relocate in Toluca (Fig. 1), the capltal of the state of Mexico. The earthquake gave the government a chance to implement its plans to rid the central area of these small shops to make room for its renovation of the Centro Historico (Historlcal Center).

It is apparent, once again, that a long history of complex relationships lay behind the crisis of the earthquake, and that the several actors responded according 
to the harm that they suffered and the interests they needed to restore. One interesting characteristic of all the responses is that none of them was one-dimensional. A second characteristic is that the responses changed over time. A third characteristic is that all parties attempted to use the changed circumstances to their advantage. Perhaps that is what is meant by rescue and restoration: not that the previous social status quo will be replaced, like a mended vase on the flreplace mantle, but that people of all classes and circumstances attempt to gather their resources and survive as best as they can. 


\section{CHAPTER VI}

\section{CONCLUSION}

This paper began with a rather conventional question regarding the impact of a natural disaster on soclety and spent considerable time discussing social process. By now It should be clear that these two issues are not separate, and in fact it is impossible to assess the impact of a natural disaster without having a very good sense of soclal process. It may seem, however, that all of this is far afleld of geography. What makes this problem geographlcal is not that Mexico city is located at any certain longitude or latitude, or even that it is bullt on an old lake bed. What makes this issue geographic is that Mexico City is one of the largest cities in the world today, that it has undergone tremendous economic, population and structural changes in the last forty years, and that the city is on a large scale what the garment district is on a smaller scale, and vice versa. What further makes this a geographical problem is that exploitation was built into the very structure of the city, and a change in that spatial struclure hud political consequences. What follows is an exploration of the Implications of that fact. 


\section{OPPORTUNITY SURFACE AND EXPLOITATION}

Richard Peet, in his article "Inequality and Poverty" (1975), argues that where Marxism and geography meet is in an understanding that in order to perpetuate heirarchical divisions among the poor and working classes, and between them and the capitalist classes, differentials of physical opportunity must be created: some schools are better than others, some neighborhoods have no schools at all. Inequality is thus transferred physically from one generation to the next through an environment of opportunities, or lack of opportunities, which surround each person. The "opportunity surface," or set of social resources, into which each person is born, does more than surround each person--it in many ways shapes his or her perceptions, awareness, values and in some ways her fate.

Each age group, each social class, each racial group, each sex, has a different typical daily "prism" in which to operate. For the lowest class and most discriminated against groups, the prism closes into a prison of space and resources (Peet 1975).

The social and spatial reality in which the costureras found themselves constituted a very limited surface of opportunities indeed. Born into poverty, lacking education, and moving along with hundreds of thousands of other people every year into the one city where all the resources they were lacking seemed to be located, they took the only jobs 
they could under their circumstances, jobs to which they spent up to two hours to get to, and which hemmed them in physicaliy in an untold number of ways, even limiting such simple acts as looking at other workers, or using the bathrooms. With such tight controls over their opportunities, it is not surprising that the costureras were not always able to see the nature of their reality. These ideas have been expressed eloquently by the costureras themselves:

When I say that we were blind to these realities, what I realiy mean to put across is that... a garment worker really has to do her work and she is bounded and her opportunity to see is pretty-much 11 mited by the four walls around what she has to do and she is constantly under the pressure of getting the work out and she doesn't often have the opportunity or time to get past the immediate demands of her situation (Corona 1986: 2).

Ms. Corona went on to explain one way that resources are denied to the costureras:

... when we are at work the schools are open and by the time that we are finished with our working day schools are closed so we have no opportunity to obtain a formal education... (Corona 1986: 2).

The power of this particular lack of opportunity goes beyond inability to read and write; it means being subject to manipulation and exploitation emotionally and psychologically as well as physically. The "romanticlzed" nature of the relationship between costureras and the owners or bosses has had to be dealt with since the formation of the Union, as have the subtle forms of brainwashing: 
And always there are efforts to keep us from seeing the situation and actually blind us to reality by offering presents, and parties at the end of the year (Corona 1986: 2).

Not all costureras, of course, were totally blind to the extremely limited daily path into which they were forced by an array of social pressures, but there was little they could do about their situation. Lupe Conde probably holds the district's record for quitting jobs. She spent her entire adult working life attempting to escape from the garment factories, but always the almost literally closed doors surrounding her forced her back. Eva Corona described the situation as being "boxed in" (Corona 1986). It is not surprising, then, that when the walls came down as a result of an earthquake, the opportunity surface of several thousand people changed. They did not automatically have access to more social resources as a result, but they did have the power to meet each other in new ways and to express their protest over their exploitation.

\section{SPATIAL CHANGE AND SOCIAL CHANGE}

The question that remains to be explored is just how the earthquake, as its own event, caused the conflicts within the garment district to shift into overt confrontation. The answer lies in the awareness of the costureras of their own part in the production process, of 
their own exploitation, of the ongoing structuration of the district. Pred (1981) suggests that:

for most individuals some awareness... of the unnatural character of a given cultural reality apparently is most likely to come about...during or after a massive or abrupt transformation of dominant institutions and their projects: when the social system malfunctions and power relations axe transformed greatly via conflict, contradiction, or external disruption; when there is a radical altering of the temporally and spatially specific dally path couplings demanded by dominant institutions; and when the way is thus paved for a new vision of what is natural (Pred 1981: 45).

This suggests that three things happened during the earthquake. One is that normal everyday spatial arrangements ("dally path couplings"), in whlch ordinary social relationships, in this case exploitive relationships, were deeply Imbedded, were radically altered, so that the costureras were able, indeed forced, to meet each other, and to meet their bosses, In new ways. second, the new circumstances in which they met each other changed the way the participants perceived their relationships. Saenger (1986) says the costureras realized what they had in common when they met each other on the streets. That slmple observation shows the importance of the link between meeting and perception. It also sums up the radical change in the lives of the costureras, who state that the earthquake shook more than the bulldings, it shook their minds too.

Third, the earthquake forced all parties to respond, and all parties responded according to their own values, 
power, needs and perceptions. As noted in Chapter I, one of the basic tenants of social theory is that "society," 1.e., disaster victims and public authorities, respond to disasters by attempting to restore the previous situation as closely as possible. The caveat offered to the theory is that where people have different interests, they have different senses of what needs to be "rescued" and what needs to be "restored." Furthermore, in this case, the perceptions of the costureras was changlng over time. The costureras not only met each other on the streets, but they faced armed men and fleeing bosses, and there were several thousand women in exactly the same circumstance, a fact which had been known before, but which had not been so visible, nor visible in an emergency perlod. Their perception of their place in the process of social production and reproduction changed instantly as a result.

\section{PEASANT VALUES IN A PROLETARIAN SETTING}

James C. Scott, in The Moral Economy of the Peasant (1976), argues that peasants (rural agricultural workers) have a value system in relation to their landlords and rulers in which conflict is likely to break out not over how much is taken, but over how much is left. He states that what will provoke peasants to revolt is a violation of the fundamental right to survive, when not enough is left over 
after taxation to live on until the next year. The expectation is that landlords and rulers will not only adfust their taxation from year to year depending on the conditions of the harvest, but will suspend taxation altogether, or even throw open their coffers to prevent outright starvation, during a bad year. When this does not happen, political revolt often breaks out.

Beth Sheehan (1986) identifled a deep moral outrage that the costureras expressed in response to the events after the earthquake:

The outrage expressed at the events that followed the earthquake was as much a moral outrage at the failure of employers and the state to meet their social obligations and moral responsibilities as it was a reaction to the miserable conditions of the garment industry (sheehan 1986: 2).

The costureras are clearly part of the stream of newly arrived working poor, whose tles to their peasant culture are not entirely severed. Their status as peasants becoming workers may help to explain their emphasis on the fact that "they were going to leave us with nothing" and "now I have nothing, no money, no Job, no place to live, nothing." Their expectation that the owners would take care of them and help them out during a time that was obviously a crisis for everybody had its roots in their recent rural backgrounds.

At the same time, however, when that help was not forthcoming, and when furthermore, the costureras saw the 
owners taking materlal, machinery and strongboxes out while women were literally calling for help, the costureras saw more clearly their position within the existent economic system. Their "proletarianization" increased several-fold. They were not only incorporated into an industrial system as exploited labor, but they also realized it. Eva Corona explained the shift from "peasant thinking" to "proletariat thinking" when she said:

Before the earthquake we thought the bosses were nice because they gave us work.... We didn't know anything about anything--we didn't know we had a $r$ ight to breaks, to holidays.... And we gave to them and gave to them, chained to those machines (proceso 11/25/85: 17).

This is the clearest statement possible of what Arroyo calls "the maturing of the working class" In Mexico (El DIa 11/19/85). The earthquake, even though it provoked a deeply engrained response rooted in peasant values, also acted to help the workers realize how much had changed. The women were no longer immigrants from the country; they realized that they were industrial workers in one of the world's largest cities, in the heart of the nation's capital and they had to protect themselves, as a class (Fig. 14).

CLASS STRUGGLE AND THE CONTROL OF SPACE

In one of the few articles attempting to apply structuration theory to actual social process, Moos (1986) says that "this view of soclety has definite political 


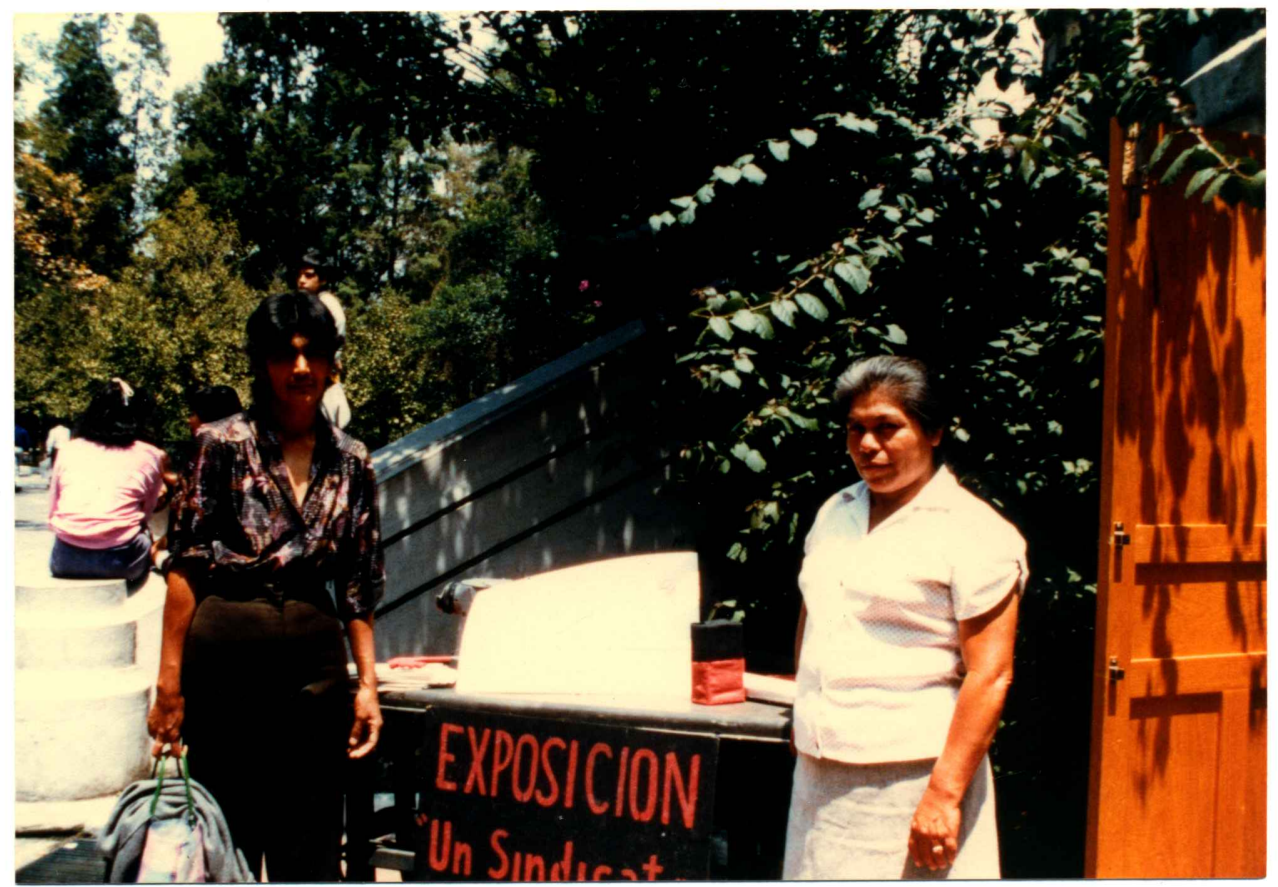

Flgure 14. Union organizers at exposition of union history.

implications" because of its analysis of the "dialectics of control" of social space by competing coalitions of actors. Soja (1979) goes even further and argues that since space is socially constructed, the social relations of production (in this case, capitalism and its attendant class struggle) permeate all social structuration. He argues, along with Lefebvre, that:

The class struggle itself is...embedded in the structure and contradictions of socially organized space. No social revolution can therefore succeed without beling at the same time a spatial revolution (Soja 1979: 5)

The most important political implication of structuration theory is that space is used for political, economic and 
social control. Segregated cities, Jewish ghettos, Indian reservations, Bantu "homelands," prisons, male-only clubs and schools, are not the symbols of power, they are the means of power. The only way to challenge that power is to wrest control over the Immediate space. In order to challenge segregation, it became necessary to move to the front of the bus. A daycare center and a collective kitchen In the heart of the garment distrlct may seem to be simply a matter of good sense, but it is more than that--it is the beginning of a radical social change. The socialization of the unpaid tasks that women do to reproduce the labor force has the potential of freelng hundreds, even thousands, of women from their fundamental exploitation as women. The question that remains to be seen is whether such changes will simply work to the benefit of garment factory owners by providing support services which make it easier of women to work at exploitive jobs. Perhaps this is the key to understanding why the formation of the Union, dramatic as it was, was not the whole revolution. It was, Instead, one step in a very long, very hard struggle to reshape all of social space and structure so that it affords opportunities to all people to realize their full potential. 


\section{LONG TERM SOCIAL CHANGE}

A final word needs to be sald about an area of soclology from which can be ldentifled a potential for some very interesting research, and that is the work on "emergent groups" (Forrest 1978; stallings 1985). These articles argue that emergent groups are inevitable in emergency situations, that they represent an outcome of natural soclal processes that respond to real needs, and that they are not inherentiy in opposition to public authority. However, the articles also state that the groups are of very short duration, for specific tasks such as search and rescue, damage assessment and "operations," are made up of very few people, and rarely formalize their relationshlps. Clearly something much different happened in this sitation, something that bears much closer examination. something happened, somewhere over time, to change a classic "emergent group" into a political organization as events, and consciousness, changed radically over a few days. The exact nature of those processes need to be examined.

In the final analysis, the emergence of the union of costureras both represents fundamental soclal change and does not represent such change. In the first place, the challenge to the political system was never a revolutionary challenge. As women demanding an independent union, they did indeed threaten the existing system of power and 
privilege within Mexico. However, the process of marching, petitioning, even going to the Presidential Palace and meeting with the president of the republic, is a tried and true method of political demand-making in Mexico. It represents, in a sense, the most rational response the women could have made in their particular circumstance. Cornelius (1974) argues that the working poor of Mexico will forgo bureaucratic process and go directly to the highest perceived political power for dealing with their demands. In this case it was the President of Mexico. Without his sanctioning of their movement, the women would have indeed represented a threat to the system and it would have been ruthlessly suppressed. By Insisting on government protection and inclusion in the system, the costureras were both protecting themselves from brutal repression and reinforcing the political status quo. Further, by demanding to be made part of the social security system, the housing system, by demanding that government daycare be extended and that they be paid as skilled workers, the costureras were asking to be made part of the system of benefits to which so many other workers belong. In addition, they were reinforcing the traditional system in which all benefits are held in the central government and are dispensed to those who organize hard enough to get them. 
This is not to say that the costureras do not represent change in Mexico, but the changes are more subtle and more permanent than the initial events implied, and though the costureras have lost many of their initial demands, the continual existence of their Union does represent long-term soclal change. First, several thousand women have political organizing experience which they did not have before. Second, many thousands of workers have recognized their place in Mexico's political economic system, and that thinking does not change, though it may take time for the social system to change. Third, the facts have come to light, and hundreds of thousands of people, in Mexico city and in other countries, are aware of the conditions in the garment district and the events of the earthquake. Fourth, supporters of the costureras met to work across class lines for the cause, at least for a short time, and that act in itself makes some social change. Finally, costureras are continuing the long-term struggle for self-help, political change, international solidarity, and a permanent place of their own in the garment district. When this writer was in Mexico city on the anniversary of the earthquake in september of 1986, a protest march took place, in which the neighborhood organizations of those areas most damaged by the earthquake protested their continued homelessness and lack of basic services. The 
costureras were part of that march and Eva Corona was one of the speakers. Then again, in March of 1987, the costureras again participated in a march to the Presidential Palace as part of the electrical workers' strike. The costureras have won a permanent place in the popular struggle in Mexico. Their fate depends on the outcome of that larger struggle. 


\section{ENDNOTES}

1. Throughout this paper, "Union" refers to El Sindicato de las Costureras 19 de septiembre; "union" refers to unions in general.

2. "Hazard" is the risk; "disaster" is the event.

3. Anthropological research has also bullt up a body of literature on the impact of natural disasters on local communities (Torry 1979b). The bulk of thls work consists of case studies and agaln, the geographic literature has not acquainted itself with this work. Torry's work, however, is an excellent starting place for geographers interested in exploring this work, and $1 t$, too, suggests areas which need further exploration.

4. According to Lisa Block, a development worker in Mexico City, La Jornada is a leftist newspaper known for rellable national reporting that does not follow the offlclal party line, but is not particularly good in its international reporting. El Dia is a paper that follows the government line nationally but has good international coverage. Excelslor has an international reputation for high standards and objectivity (along the lines of the Christian Science Monitor), and Uno Mas Uno is a leftist newspaper known for its rigorous economic research (Block interview 1987).

5. The peso was valued at approximately 350 to the U.S. dollar in september of $1985 ; 750$ to the U.S. dollar in September of $1986 ; 1000$ to the U.S. dollar in March of 1987.

6. Mexico's economy remains one of the most nationalized economies of the capitalist world. The government's share of investment has consistently been about 408 for the last forty years (Deross1 1970).

7. The middle class was also included in the political system, through a set of organizations collectively referred to as the "popular" sector. 
8. The conditions of the garment shops were not the only secrets brought to light by the earthquake. The central police headquarters were also damaged, and beaten prisoners were found inside. 


\section{REFERENCES CITED}

Books, Articles, Interviews

Alonso, Jose Antonio 1983. "The Domestlc Clothing Workers in the Mexican Metropolis and Their Relations To Dependent Capitalism." In Women, Men, and the International Division of Labor, J. Nash and M.P. Fernandez-Kelly (eds), 161-172. Albany, N.Y.: SUNY Press.

Alvarez, Roman 1985. "El Temblor." Clencla Tecnica. Mexico City, Mexico.

Baker, G.W. and Chapman, D.W. (eds) 1962. Man and Soclety in Disaster. New York: Basic Books.

Barrows, Harlan 1923. "Geography as Human Ecology." AAG Annals 13, 1-14.

Barton, A.H. 1963. Soclal organization under stress: A Sociological Review of Disaster studies. Washington D.C.: National Academy of Sclences/National Research Council.

Barton, A.H. 1969. Communities in Disaster. New York: Doubleday.

Blalkie, Plers 1985. The Political Economy of soll Erosion in Developing Countries. New York: Longman Press.

Block Intervlew 1987. Lisa Block, development worker, interview with author, Mexico City, Mexico, 2/23/87.

Brunn, stanley and J. Wlllams 1983. Cltles of the World. New York: Harper \& Row.

Burton, Ian and K. Hewitt 1974. "Ecological Dimensions of Environmental Hazards." In Human Ecology, F. Sargent (ed), 253-283. Amsterdam: North-Holland Pub. Co.

Burton, Ian, R. Kates and G. White 1978. The Environment as Hazard. New York: Oxford University Press. 
Carrillo Interview 1987. Teresa Carrillo, researcher for Union, interview with author, Mexico City, Mexico, $3 / 2 / 87$.

Castells, Manuel 1982. "Squatters and Politics in Latin Amerlca: A Comparative Analys is of Urban Social Movements in Chile, Peru and Mexico." In Towards a Political Economy of Urbanization in Third World Countries, H. Safa (ed), 249-282. London: Oxford University Press.

Cockcroft, James D. 1983. Mexico: Class Formation, Capital Accumulation, and the state. New York: Monthiy Review Press.

Copans, Jean 1983. "The Sahelian Drought: Social sciences and the Political Economy of Underdevelopment." In Interpretations of Calamity from the viewpoint of Human Ecology, $K$. Hewitt (ed), 83-97. London: Allen and Unwin.

Corona, Evangelina 1986. Presentation to Conference on Micro-Chip Technology: Its Impact on the Lives of Women Workers. (October 12) Manila, Philippines.

Cornelius, Wayne A. 1974. MUrbanization and Political Demand Making: Political Particlpation Among the Mlgrant Poor in Latin American Cities." American Political Science Review 68, 1125-1146.

Costurera Group Interview 1986. Union meeting with author, through Mujer a Mujer Program, Mexico clty, Mexico, $9 / 9 / 86$.

Degg, Martin R. 1986. "The 1985 Mexico Earthquake." Modern Geology 9, 1-23.

Derossi, Flavia 1970. The Mexican Entrepeneur. New York: organization for Economic Co-operation and Development (OECD).

Dominguez, Jorge (ed) 1982. Mexico's Political Economy: Challenges at Home and Abroad. Beverly Hills: Sage.

Durand, Carmen and Esperanza Tunon 1977. "El Trabajo Femenino en la Industria de la confeccion." Economia InEorma 4, 12-15.

Dynes, R.R. 1970. Organized Behavior in Disaster. Lexington MA: Heath. 
Eckstein, Susan 1977. The Poverty of Revolution: The state and the Urban Poor in Mexico. Princeton NJ: Princeton University Press.

ECLA (Economic Commission for Latin America). United Nations 1985. Damage Caused by the Mexican Earthquake and Its Repexcussions Upon the Country's Economy. New York: United Nations.

Edwards, P.K. and Hugh Scullion 1982. The Social organization of Industrial Conflict: Control and Resistance in the Workplace. Oxford: Basil Blackwell.

El Dia. See References Cited: Newspapers.

Expansion 1984. "Las 500 Mas Altas Negocios de 1983." Vol. 16, Aug. 15, 152-187.

Form, w. and S. Rosow 1958. Communitles in Disaster. New York: Harper and Row.

Forrest, T.R. 1978. "Group Emergence in Disasters." In

Disasters: Theory and Research, E.L. Quarantel11 (ed), 105-125. London: Sage.

Gregory, Derek 1985a. "Suspended Animation: The stasis of Diffusion Theory." In Social Relations and spatial. structure, D. Gregory and J. Urry (eds), 296-336. New York: St. Martin's Press.

Gregory, Derek and J. Urry 1985b. Social Relations and spatial structure. New York: st. Martin's Press.

Guerrera Interview 1987. Conchita Guerrera, costurera and Union organlzer, Interview with author, Mexico city, Mexico, 3/2/87.

Hamilton, Nora 1982. The Limits of state Autonomy: PostRevolutionary Mexico. Princeton NJ: Princeton University Press.

Hamilton, Nora 1984. "State-Class Alliances and Conflicts: Issues and Actors in the Mexican Economic Crisis." Latin American Perspectives 11, 6-32.

Henry, James S. 1986. "Third World Debt Hoax: Where the Money Went." The New Republic, 194 (Ap. 14), 20-23. 
Hewitt, Kenneth 1983. Interpretations of Calamity from the viewpoint of Human Ecology. London: Allen and Unwin.

Hispanoamericano 1986. "La Republica en Cifras." Vol. 2291, (Apr. 8), 22 .

Hodges, Donald and G. Ross 1983. Mexico 1910-1982: Reform or Revolution? London: zed Press.

INEGI (Instituto Nacional de Estadistica Geografia e Informatica) 1984. La Industrla Text11 y del Vestido en Mexico, 1970-1982. Mexico, D.F.: INEGI.

INEGI (Instituto Nacional de Estadistica Geografia e Informatica) 1986. La Industria Text1l y del vestido en Mexico, 1976-1985. Mexico, D.F.: INEGI.

Informacion Obrera 1985. "Cuadernos de Insurgencla sindical: Costureras, Un Sindicato Nacido de los Escombros." Rueblo: Mexico, D.F. (Nov. 4).

International Bulletin 1987. "International solidarity." Mexico City, Mexico: 19th of september Union (May 20), 5 .

Iracheta, Alfonso 1982. "La Ocupacion del suelo en los Municiplos Conurbanos con la Cludad de Mexico." El Sue 10. Recurso Estrateglico para el Desarrollo Urbano. Toluca, Mexico: Universldad Autonoma del Estado de Mexico.

Kates, Robert 1971. "Natural Hazards in Human Ecological Perspective: Hypothesis and Models." Economic

Geography 17, 438-451.

Kates, Robert, et al 1973. "The Human Impact of the Managua Earthquake." Science 182 (Dec. 7), 981-990.

Kerr, R.A. 1985. "Predictable Earthquake Damage." Sclence 230 (Nov. 8), 653 .

La Jornada. See References C1ted: Newspapers.

Lamas, Marta 1986. "El Movimiento de las Costureras." fem 10. 4-10.

Levi de Lopez, Silvana 1981. "Estructura y Desarrollo del Distrito Comercial y de serviclos en el area Central de la Ciudad de Mexico." Boletin de la socledad Mexicana de Geografla y Estadistica 127, 179-216. 
Looney, Robert 1985. Economic Pollcymaking in Mexico:

Factors Underlying the $1982 \mathrm{Cr} 1 \mathrm{~s} 1 \mathrm{~s}$. Durham NC: Duke University press.

Lovera, Sara 1986. "Costurera Sin Remed10: Entrevista con Lupe Conde." fem 10, 11-13.

Marston, Sallie 1983. "Natural Hazards Research: Towards a Political Economic Perspective. A Review Essay."

Pol1tical Geography Quarterly 2, 339-348.

McDowell, L. 1983. "Towards an Understanding of the Gender Dlvision of Urban space." Environment and Planning D: Soclety and Space 1, 59-72.

Me1llassoux, Claude 1974. "Development or Exploltation: Is the Sahel Famine Good For Bus Iness?" Revlew of African Political Economics 1, 27-33.

Milet1, Dennis, et al 1975. Human systems in Extreme Environments: A Soclological Perspective. Boulder : University of Colorado.

Mitchel1, James K. 1974. "Natural Hazards Research." In Perspectives on Environment, M. Manners (ed), 311-341. Washington D.C.: American Association of Geographers.

Moos, A.I. and M. J. Deax 1986a. "Structuration Theory in Urban Analysis: 1. Theoretical Exeges is." Environment and Planning $A$ 18, 231-252.

Moos, A.I. and M. J. Dear 1986b. "structuration Theory in Urban Analysis: 2. Empirical Application." Environment and Planning $A$ 18, 351-373.

Moreno Toscano, Alejandro 1982. "La "Crisis' en la Ciudad." In Mexico Hoy, P. Gonzalez Casanova and E. Florescano (eds), 152-176. Mexico D.F.: Siglo XXI.

NYT (New York Times). See References Cited: Newspapers.

O'Keefe, P., K. Westgate and B. Wisner 1976. "Taking the Naturalness out of Natural Disasters." Nature 260 (Ap. 15), 566-567. 
Peck, Dallas 1985. "Statement." Hearlngs Before the Subcommittee on science, Technology and space. Senate Committee on Commexce, science and Transportation. 99th Congress (Oct. 3). Washington D.C.: Government printing office.

Peet, Rlchard 1979. "Inequality and Poverty: A MarxistGeographic Theory." AAG Annals 65, 564-571.

Perez Sanroman, L. 1986. "Survey of Man-Made Fiber

Production." Report to Dept. of state from U.S.

Embassy, Mexico City, Mexico. Ref. No. A-39 (June 23).

Pommier, Paulette 1982. "The Place of Mexico City in the Nation's Growth: Employment Trends and Policles." International Labor Review 121, 345-360.

Pred, Allan 1981. "Power, Everyday Practlce and the Discipline of Human Geography." In Space and Time in Geography: Essays Dedicated to Torsten Hagerstrand, A. Pred (ed), 30-55. Sweden: Royal Unversity of Lund.

Pred, Allan 1984. "Place as Historlcally Contingent Process: structuration and the Time-Geography of Becoming Places." AAG Annals 74, 279-297.

Pred, Allan 1985. "The Soclal Becomes the spatial, the Spatial Becomes the Social: Enclosures, Social Changes and the Becoming of Places in the Swedish Provice of skäne." In soclal Relations and spatial structure, D. Gregory and J. Urry (eds), 297-336. New York: st. Martin's press.

Prince, Samuel H. 1920. Catastrophe and Soclal Change: Based Upon a Sociological study of the Hallfax Disaster. New York: Columbia University Press.

Proceso. See References Cited: Newspapers.

Quarantel11, E.L. (ed) 1978. Disasters: Theory and

Research. London: Sage publications.

Ramos, Carmen 1986. "Helando, Tejlendo, Cosiendo, Siempre Mal Viviendo..." Eem 10, 14-17.

Riding, Alan 1985. Distant Neighbors: A Portrait of the Mexicans. New York: A.A. Knopf. 
Rudolph, James D. (ed) 1984. Mexico: A Country study. Washington D.C.: Forelgn Affalrs studles, American University.

Saenger, Ellen 1986. "Textlles and clothing: The Bare Threads of Survival." Business Mexlco (Dec.), 54-59.

Schlagheck, James L. 1980. The Political, Economic, and Labor Climate in Mexico. Philadelphia: University of Pennsylvania.

Scott, Ian 1982. Urban and Spat1al Development in Mexico. Baltimore: Johns Hopkins University Press.

scott, James C. 1976. The Moral Economy of the Peasant: Rebelilion and subsistence in southeast Asia. New Haven: Yale University Press.

Sheehan, Beth 1986. "Mexlcan Garment Workers: Women on the Cutting Edge." The Daily Callfornian, (Dec. 8), 2.

Sjoberg, Gideon 1962. "Disasters and Soclal Change." In Man and Soclety in Disaster, G.W. Baker and D.W. Chapman (eds), 356-384. New York: Baslc Books.

Smith, Peter H. 1977. "Does Mexico Have a Power El1te?" In Authoritarianism in Mexico, J.L. Reyna and R. Welnert (eds), 129-154. Philadelphia: Institute for the study of Human Issues.

Smith, Peter H. 1979. Labyrinths of Power: Political

Recruitment in 20th Century Mexico. Princeton $\mathrm{NJ}$ :

Princeton University Press.

Soja, Edward and Costis Hadjimichalis 1979. "Between Geographlcal Materlallsm and spatial Fetlshism." Antipode 11, 3-11.

Sorokin, P.A. 1942. Man and soclety in Nature. New York: Dutton.

stallings, Robert and E. Quarantell1 1985. "Emergent citizen Groups and Emergency Management." Public Adminlstration Review 45, 93-100.

Stephens, Lynn and Green, S. (eds) 1979. Disaster Assistance: Appraisal, Reform and New Approaches. New York: SUNY Press. 
Susman, P., P. O'Keefe and B. Wisner 1983. "Global Disasters, A Radical Interpretation." In

Intepretations of Calamity from the viewpoint of Human Ecology, K. Hewitt (ed), 263-283. London: Allen and Unwin.

Thompson, stephen 1982. Trends and Developments in Global Natural Disasters, 1947 to 1981. Boulder: University of Colorado Instltute of Behavioral science, Natural Hazard Research Working Paper 45.

Thrift, Nigel 1983. "On the Determination of social Action in space and Time." Environment and Planning D: Society and space 1, 23-57.

Torry, Willlam 1979a. "Hazards, Hazes and Holes: A Critique of The Environment as Hazard." Canadian Geographer 23, $368-383$.

Torry, Wlllam 1979b. "Anthropologlcal studies in Hazardous Environments: Past Trends and New Horizens." Current Anthropology 20, 517-540.

Uno Mas Uno. See References C1ted: Newspapers.

U.S. AID (United States Agency for International

Development). Office of Forelgn Disaster Assistance 1986. Final Disaster Summary Report: Mexico-1985 Earthquakes. Washington D.C.: Government Printing Offlce.

Waddell, Exic 1977. "The Hazards of Scientism: A Review Article." Human Ecology 5, 69-76.

Watts, Michael 1983. "On the Poverty of Theory: Natural Hazards Research in Context." In Interpretations of Disaster from the Viewpoint of Human Ecology, $K$. Hewitt (ed), 231-262. London: Allen and Unwin.

Ward, Peter M. 1985. "Urban Renovation and the Impact on Low-Income Families in Mexico City." Urban studies 22, 188-207.

Ward, Peter M. 1986. Welfare Pol1tics in Mexico: Papering over the cracks. Cambridge University: Allen and Unwin. 
Wijkman, A. and L. Timberlake 1984. Natural Disasters: Acts of God or Acts of Man? England: Earthscan.

WSJ (Wall street Journal). See References Clted: Newspapers.

\section{Newspapers}

E1 D1a

10/9/85 Rajchenberg, Enrlque. "El Sismo Reve10 Condiclones de Trabajo Decimononicas."

10/21/85 Howard, Georgina. "La Mayorla de las Maquiladoras Eran Obligadas a Laborar 10 Horas Diarios."

11/19/85 Arroyo, Torres. "Costureras sin vias de solucion."

6/15/86 No Byline. "No Ha Variado la situacion Laboral de 50 Por clento de las Costureras."

\section{La Jornada}

$10 / 3 / 85$ Becerril, Andrea. "Se Organizan las Costureras Damn ificadas."

10/4/85 Lovera, Sara. "Sorprevisa Suspension de Labores En Una Fabrica de Ropa."

10/9/85 Rodriguez, Luis. "Obligan a Obreras Textiles a Reiniciar Labores."

10/10/85 Lovera, Sara and Becerr11, Andrea. "Poca Antencion en el Rescate de Obreras de la Confecclon."

10/12/85 Hernandez, Bolivar. "La Industrla del Vestido, Al Desnudo."

10/16/85 Rodr1guez, Javier. "Sin Responsabjlidad la CNIV en Explotacion de Costureras."

10/21/85 Castro, Hermeneg11do. "El Domingo, Aspiracion de 20 Mil Costureras de Neza."

10/26/85 Lovera, Sara. "Colas Para Aflllarse al sind lcato." 
11/25/85 Lovera, Sara. "La situacion de las Costureras Era Conocida Ya Desde Antes."

11/30/85 Lovera, Sara. "Las Costureras, Bajo Virtual Estado de Tortura Permanente."

6/27/86 Lovera, Sara. "Solldarldad y Apoyo gara Trabajadoras de la Costura."

New York TImes

10/23/86 stockton, William. "Hard-Hit Mexico Tries to Cope." P. 1+.

\section{Proceso}

10/21/85 No Byline. "Flngldas Sorpresas, Acusaclones, Promesas y las Costureras Siguen Explotadas o Robadas." pp. 28-29.

11/4/85 Corro, Salvador. "Con las Costureras Farel1 solo Formo un sindlcato de Damniflcadas."

11/25/85 Poniatowska, Elena. "La Dirigente Evangelina Corona: "Como No Sabiamos Nada de Nada, Creiamos Que los Patrones Eran Buenos'."

Uno Mas Uno

10/18/85 No Byl1ne. "En La Clandestinidad $80 \%$ de Talleres de Costura."

$12 / 31 / 85$ No Byline. "Centrales obreras oficiales Pretenden Desaparecer el sindicato de Costureras."

4/14/86 Guzman, Juan. "Patrones y Autoridades Laborales No Han Cumpllo con las Costureras: El sindicato."

Wall street Journal

10/4/85 Kandell, Jonathan. "Mexico City's Growth, Once Fostered, Turns Into Economic Burden." p. $1+$. 
OTHER SOURCES

Books, Articles, Interviews

Alonso, Jose Antonio 1986. "Costureras, Sindicalismo $y$

Crisis." Presentation to the First Forum on the social Problems of Women, College of Soclology of Mexico (March 14). Mexico City, Mexico.

Arzipe, Lourdes and J. Aranda 1981. "The Comparative Advantages' of Women's Disadvantages: Women Workers in the strawberry Export Arglbusiness of Mexico." Signs $7,453-473$.

Bener1a, Lourdes and Gita Sen 1981. "Accumulation, Reproduction and Women's Role in Economic Development: Boserup Revisted." Signs 7, 270-298

Boserup, Ellen 1970. Women's Role in Economic Development. London: Allen and Unwin.

Browett, John 1984. "On the Necessity and Inevitability of Uneven spatial Development Under Capltalism." International Journal of Urban and Reglonal Research 8, 155-176.

Camp, R.A. 1985. "The Political Technocrat in Mexico and the Survival of the Political system." Latin American Research Review 20, 97-118.

Cant, R.G. 1986. "Famine in the Sahel: Natural Disaster or structural Violence?" New Zealand Journal of Geography $80,2-5$.

Carrillo, Jorge and A. Hernandez (1985). Mujeres Fronterizas en la Industria Maquiladora. Mexico D.F.: Centro de Estudios Fronterizas del Norte de Mexico.

Christopherson, Susan 1983. "The Household and Class Formation: Determinants of Residential Location in Cuidad Juarez." Environment and Planning D: Soclety and space $1,323-338$. 
Eckstein, Susan 1976. The Impact of Revolution: A

Comparative Analysis of Mexico and Bollvia. Beverly Hills: Sage.

Eckstein, Susan 1977. "The State and the Urban Poor." In Authoritarianlsm in Mexico, J.L. Reyna and R.S.

Weinert (eds), 23-46. Philadelphla: Institute for the study of human Issues.

Economist 5/18/85. "Mexico Falls to Pass Politics, Philosophy and Economics." Vol. 295, 71-72.

Ehrenreich, Barbara and A. Fuentes 1981. "Life on the Global Assembly Line." Ms 9, 53-59+.

Elson, Diane and R. Pearson 1981. "Nimble Fingers Make Cheap Workers: An Analys is of Women's Employment in Third World Export Manufacturing." Feminist Review 7, 87107 .

Expansion 1986. "La Revista de Negocios de Mexico." Vol 18, Aug. 20, 168+.

Fernandez-Kelly, Marla Patricia 1983. For We Are Sold, I and My People: Women and Industry in Mexico's Frontier.

Albany: SUNY Press.

Forbes, D.K., N. Thrift and P. Williams 1983. "Socjal Relations in Space: Books in 1982." Environment and Planning D: Soclety and space 1, 355-364.

Friedmann, John 1972. "The Spatial Organization of Power in the Development of Urban Systems." Comparative Urban Research 1, 5-42.

Frobel, F., J. Helnrichs and O. Krege 1980. The New International Division of Labor. New York: Cambridge University Press.

Fuentes, Annette and B. Ehrenrelch 1984. Women in the Global Factory. (No location): South End Press.

Gambles, Peter 1985. "Aspects of the Mexican Earthquake." Nature 317 (sep. 26), 216.

Garcia de Miranda, Enriqueta and Z. Falcon de Gyves 1984. Neuvo Atlas Porrua de la Republica Mexico. Mexico, D.F.: Editorlal Porrua. 
Grunwald, Joseph 1985. "The Assembly Industry in Mex1co." In The Global Factory, J. Grunwald (ed), 137-178.

Washington D.C.: Brookings Institute.

Hay, Alan 1985. "The World as a spatial Economic system." Geography 70, 97-105.

Hellman, Judith A. 1978. Mexico in Crisis. New York: Holmes and Meler.

Hewitt, Kenneth and I. Burton 1971. The Hazardness of a Place: A Regional Ecology of Damaging Events. Toronto: University of Toronto.

Hewitt, Kenneth 1983. "The Idea of Calamity in a Technocratic Age." In Interpretations of Calamity from the Vlewpoint of Human Ecology, $K$. Hewltt (ed), 3-32. London: Allen and Unwin.

Imrie, R.F. 1986. "Work Decentralization From Large to Small Firms: A Preliminary Analys is of subcontracting." Environment and Planning A 18, 949-965.

Jensen, Joan and S. Davidson 1984. A Needle, A Bobbln, A strlke: Women Needleworkers in Amer lca. Philadelphla: Temple University press.

LaGory, Mark and J. Piplan 1981. Urban Social Space. Belmont CA: Wadsworth Pub. Co.

"La Lucha por el Suelo y Los Movimientos Urbanos Populares: Caracteristicas y Evolucion." Presentation to the Congress of the Planning Soclety. Morelia, Mlchoacan: UCP-USCOVI .

Lapple, Dieter and P. van Hoogstraten 1980. "Remarks on the Spatial structure of Capitalist Development: The Case of the Netherlands." In Regions in Crisis: New Pexspectives in European Reglonal Theory, J. Carney, $R$. Hudson and $J$. Lewis (eds), 117-167. London: Croom Helm.

Lukes, steven 1977. Power: A Radical Vlew. New York: Macmillan.

Millares, Jorge and A. Escribano 1966. Atlas Porrua de la Republica Mexico. Mexico, D.F.: Editorial Porrua. 
Mitchell, James $K$. and A. Bernstein 1987. "Toward a Less Hazardous World: A Proposal to Establish an International Decade of Hazard Reduction." Washington D.C.: National Academy of Sciences.

NACLA (North American Congress on Latin America) 1977. "Capital's Flight: The Apparel Industry Moves South." NACLA's Latin Amerlcan Emplre Report 11.

NRC/CEE (National Research Council/Committee on Earthquake Engineering) 1986. Research Agenda: Learning from the 19 September 1985 Mexican Earthquake. Washington D.C.: NRC.

NRC/EERI (National Research Counc11/Earthquake Englneering Research Institute) 1985. Impressions of the GuerreroMlchoacan, Mexico Earthquake of 19 September 1985: A Preliminary Reconstruction Report. Washington D.C.: NRC.

Newell, Roberto 1984. Mexico's Dilemma: The Political orlgins of Economic Crisis. Boulder: Westview Press.

olson, Wayne 1985. "Crisis and social Change in Mexlco's Political Economy." Latin Amerlcan Perspectives 12, 728.

Peterson, I. 1986. "Mexico City's Earthquake: Lessons in the Ruins." Sclence News 129 (Jan. 18), 36.

Safa, Helen I. 1977. "The Changlng Class Composition of the Female Labor Force in Latin America." Latin American Perspectives 4, 126-136.

Safa, Helen I. 1981. "Runaway shops and Female Employment: The Search for Cheap Labor." signs 7, 418-433.

Shrestha, Nanda and J. Patterson 1987. The Dependent state, Economic Underdevelopment, and High Population Growth: Lat in America Considered. Paper presented at the annual meeting of the AAG, Portland, oregon.

Soja, E.W. 1971. The Political organization of space. Washington D.C.: American Association of Geographers.

St1lwell, Frank 1978. "Competing Analyses of the Spatial Aspects of Capitalist Development." Review of Radical Political Economics 10, 18-27. 
Thrift, Nigel 1985. "Flles and Germs: A Geography of knowledge." In Soclal Relations and spatial structure, D. Gregory and J. Urry (eds), 366-397. New York: st. Martin's Press.

Torry, William 1980. "Urban Earthquake Hazard in Developing Countrles: squatter settlements and the outlook for Turkey." Urban Economics 1, 317-327.

Transactions of the American Geophysical Union 1986. "The Great Michoacan, Mexico Earthquake of 19 september 1985: Some Selsmological Aspects." Vol. 67 (Feb. 18), $84-85$.

Transactions of the Amerlcan Geophyslcal Union 1986. "A Tale of Two citles, One and the Same." Vol. 67 (Feb. 18), 85 .

Unikel, Luis 1975. "The Dynamics of Growth of Mexico City." Ekistics 233, 251-254.

Walker, Richard A. 1978. "Two Sources of Uneven Development Under Advanced Capitalism: Spatial Differentiation and Capital Mobility." Review of Radical Political Economics 10, 28-38.

Walker, Richard A. 1979. "Revlew of The Environment as Hazard." Geographical Review 69, 113-114.

Ward, Peter M. 1976. "Intra-City Migration to squatter Settlements in Mexico City." Geoforum 7, 369-382.

Welsburd, S. 1985. "A Long and Late Quake." Sclence News 128 (sep. 28), 196-97.

Welsburd, S. 1986. "Damage In Mexico: A Double Quake." Sclence News 129 (Jan. 11), 25.

White, Gilbert F. 1974. Natural Hazards: Local, National. Global. New York: Oxford University Press.

White, Gilbert F. 1978. "Natural Hazards and the Third World--A Reply." Human Ecology 6, 229-231.

White, Gilbert F. 1981. "The Future of Hazards Research: A Reply to William I. Torry." Canadian Geographer 25, $286-289$. 
Wong, Aline 1981. "Planned Development, Social

stratification and the sexual Division of Labor in Singapore." Slgns 7, 434-452.

\section{Newspapers}

El Dia $10 / 4 / 85$ to $6 / 16 / 86$.

Excelsior $10 / 10 / 85$ to $7 / 5 / 86$.

La Jornada $9 / 28 / 85$ to $10 / 24 / 86$.

New York Times 1986. "Nelghbor in Distress: Mexico's Crisis and the U.S," 10/19-10/25.

10/19/86 Pear, Robert. "Hard Times in Mexico Causes Concern in U.S." p. 1+.

10/22/86 Riding, Alan. "Mexico's Embattled Ruling Party: The Calis for Change Grow Loud." p. 1+.

Uno Mas Uno $10 / 5 / 85$ to $6 / 27 / 86$.

Wall street Journal

9/26/85 Huey, John and $s$. Grazler. "Mexico's Future Grows Even More Incalculable After the Earthquake." p.
$1+$. 
APPENDIX A

LOCATIONS AND CHARACTERISTICS OF THE CONFLICTS, From La Jornada $9 / 19 / 85$ to $10 / 26 / 85$

S1te 1. 138-164 San Antonio Abad. Dlmenslon Weld, Topeka, Amal, Carnival, Le Petit, Creaclones Lody, Baby Duy.

$9 / 28 / 85$. 600 workers were still trapped in the bullding, some of them still allve. Volunteers and rescuers, using shovels and plcks, took out 25 survivors and 100 bodles. survivors were taken to a makeshlft emergency medical center set up nearby, and then were helicoptered to Humana Hospital. All rescue work had been done by famliles and volunteers untll the $26 \mathrm{th}$, when a team of French and U.S. rescuers were dispatched by the government, in response to several petitions by workers at Amal. On the 27th, four bodles were taken out, and seven more were discovered, almost in a row, but they were trapped under slabs of concrete, and steel wire.

$10 / 3 / 85$. The majority of the owners had begun to take out their materials, clothes and machines, leaving the survivors and the families of the workers who were kilied uncompensated. The steering Committee for the Garment Workers Injured by the Earthquake (La Prometora de Costureras Damnlficadas) was formed with three goals in mind: to protect the rights of the workers, some of whom had 15 years of senlority; to prevent the owners from fleeing; and to take advantage of legal means of redress. As a labor organization, they could petition the labor authorlties for an embargo on the goods in the garment shops until all disputes were settled.

$10 / 5 / 85$. Owners at several of the factories, including Dimension Weld, offered a settlement of 15 days' pay, payable in six months. The Boards of Conciliation and Arbitration were not functioning and the owners had begun to dislodge the workers who were guarding machinery in the vicinity of the shops. A stalemate was settling in. 
$10 / 6 / 85$. Workers made an appeal to the public for support in helping to impede the owners in their taking out of the machinery. Workers from Topeka and Amal joined workers at Dimension Weld and formed a circle in order to prevent the removal of 30 machines, but that was not enough to carry on the action. The workers blamed the owners and the government for the attacks against them by unidentified men, both in the ir camps at night and during the confrontations at the shops.

10/7/85. Sixty bodies remained inside the bulldings. The volunteers could not get to them, as it cost 25,000 pesos per hour to rent heavy machinery for removing the rubble, and there were not enough volunteers to do the work. At the same time, workers were guarding machinery and hoping for legal or popular support. Five policemen arrived in the night to dislodge the workers and the families so that the owners could take out a little of what they had salvaged. Some 1,000 workers of Topeka and Carnival had spent three days encamped near the materials, having been offered 5,000 to 10,000 in compensation (approximately one week's pay). Several government officials had arrived and made promises to deal with the situation, but nothing had begun. The Arbitration and Conciliation Boards were still not functioning. The workers were asking for legal help and financial support. At Baby Duy, the owner had told the workers not to go near the bullding or they would be reported to the police. At Lody, the workers had been sent back to work (on the third floor of the building), because the inspectors had not yet been around.

10/9/85. Workers at Lody, Le Petit and Carnival abandoned the buildings as unsafe after first going back to work on request of the owners. The owners of Carnival, Kayser and le petit warned the workers that they would be accused of abandoning their jobs if they refused to go back inside the buildings. The federal government finaliy set up an ad hoc Board of Conclliation and Arbitrage and its flrst action was to place a 38 million peso embargo on the 30 machines held by the workers of Dimension Weld. This was the flrst successful embargo placed on owners' equipment. Lawyers for the workers had five more in progress, and announced that fifteen more would be filed within the week. Workers announced that they were demanding an immediate opening of a local Board of Conciliation (the federal government had taken over the local 
Board's duties); deliverance of death certiflcates to families of garment workers who were killed so the families could petition for compensation; creation of a contract law dealing with the entire industry; and end to the exploitive practice of blank labor contracts.

10/12/85. The owners of Carnival pald workers $50 \%$ of their demand and sent them "on vacation." The federal Conclilation Board was working around the clock, and workers were coming forward to demand protection. Fifty workers from le petit asked for protection and 100 from Lody did the same. Representative Hilda Anderson from the women's division of the CTM toured the area and assured the workers that the government would render assistance to the workers with their claims.

$10 / 17 / 85$. The workers of Lody were fired with $50 \%$ of their compensation rights, in spite of Board's response to workers' demands for protection. The workers of Dimension Weld announced that they were attempting to form a cooperative to continue working.

$10 / 23 / 85$. Rescue workers demanded more attention to the buildings by government officials. Dozens of bodies were still trapped inside, and the heavy machinery sent to do rescue work had been appropriated to rescue goods instead. Rescue workers also announced that they had taken a large amount of personal goods out of the bulldings and asked the garment workers to come and plck them up.

Site 2. San Antonio Abad and Jose T. Cuellar streets. The encampment of the costureras.

Site 3. 186 Manuel J. Othon. Kayser.

$10 / 9 / 85$. Workers were reguired to return to work on two of the five floors, even though the rest of the bullding was totally destroyed. The workers panicked when rescue workers caused a loud crash that shook the floors and they left the buildings immediately. A policeman in the area sald that the bullding was in extremely bad shape and that it "makes a person afrald to go in there." Alberto Levi and Jose Konieszny of 
Provest were studying the possibility of relocating in this bullding because "there was little damage."

$10 / 11 / 85$. The bullding was closed by the authorities as being unsafe.

$10 / 18 / 85$. David Meta, owner of Kayser, sent 40 workers "on vacation" after they helped him take out his equipment after the bullding was declared unsafe. They moved it to 275 Manuel Delgado, to a shop owned by Meta's brother. In a private meeting with the workers, Meta threatened to blacklist any workers who formed any denunclations. The workers went ahead and denounced the holder of their union contract, whom they sald had been in hiding since the earthquake. Also, under pressure from the workers, Meta signed with the offlce of Worker Defense that he would pay workers for the time that they were off work during the moving of the equipment, but then he fired two workers and threatened to do the same to the others unless they kept quiet.

Site 4. 26 Agustin Delgado. No name given for the shop.

$10 / 9 / 85$. Workers abandoned the bullding as unsafe after first going back to work inside it.

Site 5. 75 clavijero. Pascual Bottling Co.

See site 11.

Site 6. 260 Garcla Diego. RopaMex.

$10 / 26 / 85$. The 27 workers of this plant had continued working "through fear." The contract holder had not shown up until the 25 th of October, more than a month after the earthquake. The union official had wanted the workers to sign a blank contract, and when they refused, he told them that they wanted everything without working for it. The labor boss sald that the new Union would have to demonstrate its ablilty to protect the workers. The workers insisted that velled threats from the union bosses who worked in collaboration with the owners had been carried out as much by psychological means as by concrete actions. 
Site 7. Bolivar and L. Boturini streets. Pantalones Ideal.

$10 / 12 / 85$. The owner, Yeroham, intended to rescue his equipment without giving compensation to workers, who had worked extraordinarily long days and worked almost without protection. The 135 workers announced that they considered official declarations of attention to their case to be contradictory, since their labor contract holder had told them that their embargo on the owner's goods would not take place for fifteen days, whlle the declarations sald that it would begin immediately.

Site 8. Bolivar and Lucas Aleman streets. Deval.

$10 / 12 / 85$. The four-story building was closed by the authorities as being unsafe, but still the owners, Manuel Romero Agullar and Eduardo Romero, made the workers work in the building, in spite of its "total" damage, including three columns broken almost in half. A delegation of twenty workers took a petition to the office of Delegacion Cuauhtemoc.

$10 / 17 / 85$. The workers succeeded in getting an embargo placed on the owners' goods for two weeks, while the dispute was being resolved.

Site 9. 80 Eje Lazlo Cardenas. No name given for the shop.

$10 / 10 / 85$. With the help of the military, fifteen workers were dislodged from the premises in three days, while twenty bodies remained trapped inside.

Site 10. 55 Izazaga. Miss Universe.

10/26/85. The factory had collapsed. The owner, Elias Michen Tuachi, offered to loan the workers 5,000 pesos. A week later he sald this would cover the week's pay for the work done during the week of the earthquake and that he would discount it from their next week's pay. Later he announced that he was relocating. 
Site 11. 175 20th de Noviembre. Piamonte.

$10 / 17 / 85$. Workers at the Pascual bottling company (site 5) gathered bedding, food, clothing and money in support of the workers at plamonte, while they were sitting on selzed goods, walting for legal settlement of their clalms. The workers of plamonte were seeking indemnification, and successfully placed an embargo on the owner's goods.

site 12. 137 Izazaga. Confecciones Yanet.

$10 / 4 / 85$. The owners were the first to take advantage of the National clothing Chamber's recommendations to suspend activities. The owners closed shop for three months, even though it suffered no injury from the earthquake, and left 21 workers without compensation or salary. The workers decided to form a cooperative, and received offers of assistance from government programs for women and for young people. With the assistance of these federal offices, the workers began to look for a location for their cooperative.

Site 13. 151 20th de Noviembre. DiGalia.

$10 / 26 / 85$. The 23 workers of this plant joined the Union. Its owner, Ezra Menasche, had suspended his operations.

Site 14. 130 Nezahualcoyotl. s1s1.

$10 / 18 / 85$. Ninety workers were obliged by the owner to work in the middle of the street, after assisting him in the rescue of his equipment. In exchange, they were given $50 \%$ of their salaries.

Site 15. Alarcon street

site 16. Doblado street

site 17. J.J. Herrero street No names given for the shops.

$10 / 12 / 85$. There were four bulldings on these streets where workers were still trapped. The rescuers here had never received any assistance. Daz Marcos Cohen, one of the owners, sald he was not worrled because he had taken most of his equipment to Texcoco and puebla, where he had other shops. He said he was fortunate 
because he only had 30 workers at his site and that since they started work at $8 \mathrm{a.m}$., they had not been hurt by the earthquake.

Site 18. Belissar1o Domingo and Republic of Chile streets. Nueva York.

$10 / 12 / 85$. Fifty workers walted for the arrival of excavators, where workers were still trapped. The owner had already taken out his goods.

$10 / 14 / 85$. Families of the workers were still demanding machinery to move the rubble. Assistance in moving the rubble had been slow and 1rregular. The owner had given one hour of his time, and a television crew had arrived to Ellm them at their work. The owner, Carlos Gonzales Moncada, had taken his goods around the corner to 55 Rep. of Chile. The workers were walting for their labor union to act on their behalf. The labor boss had told them that they could not place an embargo on the owner's goods, and that the owner had offered to relocate the workers.

site 19. 87 peru street. No name given for the shop.

10/26/85. A six-floor building was damaged but still standing. Of the 80 workers, 27 joined the Union. The owner, Isaac Ixtepesqui, had already taken out his equipment.

Site 20. Republic of Ecuador, near the corner of Paraguay street. star Dance.

$10 / 17 / 85$. Th1s bullding was sltuated between two buildings that had been completely destroyed. This four floor building sustained major damage, on top of its already existing rotten stairs and columns. The owners, Ruben Bucay and Manuel Farca, had required the workers to go back to work. There were stili bodies trapped inside. The bullding had been placed on a list as inhabitable, but then changed to uninhabitable, and the workers refused to enter. They offered to go back to work if there was an embargo placed on the owners' goods. 
$10 / 23 / 85$. The owners pledged to violate the requirements placed on them by government mediating offices, and took out their goods and hid them.

S1te 21. 77 Ecuador. Maquilas serrat.

$10 / 26 / 85$. The workers Jolned the Union. The owner, Camerina Torres, offered workers 20,000 to 30,000 pesos in compensation. Some of the workers had eleven years seniority.

Site 22. 153 Palma Norte. Gales shirts.

10/3/85. A group of 80 workers from Gales shirts denounced to Fidel velazquez that the owners, Elias and Alberto Fallena Adisi, took advantage of the confusion and the earthquake to take all their equipment from the their shop, with the intention of disappearing. The workers were unable to resolve their conflict with the owners because there was no Board of Conciliation functioning. They reported that other workers in the district were having similar problems. If the owners did take out their machinery, they would be completely justifled in the act if the recommendations of the attorneys for the National Clothing Chamber went into effect. These recommendations would declare the entire industry in the garment center of downtown Mexico City in a state of emergency and therefore all work could be suspended, which could affect up to 40,000 workers. The suspension could place the industry in a "state of exception" in regard to complying with federal laws concerning pay, soclal security, and indemnities. 


\section{APPENDIX B}

\section{CHRONOLOGY OF THE FORMATION OF THE UNION}

Sept. 19, 1985. 7:19 a.m. an earthquake destroys an estimated 500 garment shops, leaving 50,000 garment workers unemployed and hundreds buried or trapped in the rubble.

Sept. 20, 1985. The army cordons off affected buildings and prohibits entry of garment workers, family members and volunteer rescue teams, while many remain trapped.

Sept. 24, 1985. Garment shop owners bring in cranes to retrieve safes, material and machinery, leaving bodies and survivors unattended. Workers hold first allnight vigil to prevent lilegal sacking of factories by owners.

oct. 2, 1985. Workers from elght factorles create the organizing Committee of Garment Workers Affected by the Earthquake--Promotora de Costureras Damnificadas.

oct. 4, 1985. First camp of displaced garment workers is established.

oct. 5, 1985. Informal protests and demonstrations become widespread in the central garment district; workers demand rescue equipment and compensation benefits due to them under Federal Labor Law.

oct. 7, 1985. First meeting of the Feminist committee in solidarity with Garment workers--400 attend.

oct. 9, 1985. Workers from 15 factorles form the Union of Garment Workers in struggle--Union de Costureras en Lucha.

oct. 13, 1985. Organization of Downtown Garment Workers-organizacion de Costureras del Centro--is formed.

oct. 17, 1985. 150 garment workers win compensation worth $\$ 38$ milition pesos. 
oct. 18,1985 . Over a thousand garment workers from 26 factorles march to the President's house to demand compensation, the reopening of workplaces and recognition of an independent union. President de la Madrid orders resolution of their demands.

oct. 20, 1985. The National Independent Garment workers' Union "19th of September" is granted reglstration-total number of affiliates nationwide is estimated to be 8,000 .

oct. 23, 1985. The "19th of september" sewing cooperative is formed by displaced workers with compensation payments; it employs 72 workers from 3 factories.

oct. 25,1985 . Groups from 23 condemned companies and 26 active ones join the new union, demanding an industrywide accord on compensation payments.

oct. 29, 1985. Employers sign an accord to compensate unemployed workers, and retract it the next day.

Nov. 4, 1985. A thousand garment workers occupy the offlces of the secretary of Labor as a last recourse to gain legal compensation for workers in 70 factories.

Nov. 7, 1985. Second march to the Presldent's house to demand solution to the demands of displaced workers.

Nov, 19, 1985. The union calls lts first strike.

Nov. 21, 1985. Workers in "Rosy Bras" begin a sit-in to demand reopening of the workplace.

Nov. 25, 1985. Garment workers march with feminists and women from neighborhood organizations to protest violence against women. Proclaimed the "Day of the Garment Worker."

Dec. 1, 1985. Union wins its first shop election.

Dec. 2, 1985. Demonstration in the central square to demand negotiations with industry heads--only 8 of 80 companies have pald compensation.

Dec. 17, 1985. Workers accept the first collectlve work contract negotiated by the "19th of september" union-the union gains 120 members. 
Dec. $21,1985.50$ workers illegally flred for union activity.

Jan. 21, 1986. A second collective work contract is signed. Jan. 24, 1986. Union wins third election.

Feb. 12, 1986. One of the largest garment companies files for nulification of the union's registration with labor authoritles.

Mar. 8, 1986. The union marches under 1 ts own banner in the International Women's Day parade.

Apr. 1, 1986. Three factories reopen workplaces for 150 workers affiliated with the union.

Apr. 21, 1986. The union calls its second authorlzed strike.

May 1, 1986. Members of the army and speclal anti-riot forces prevent union members from joining the International Workers' Day march. Garment workers and supporters are beaten, some escape to foln march.

May 12, 1986. Mother's Day--over five hundred union members march to government offices to protest the repression of May 1 and demand free and voluntary motherhood.

Aug. $12 \& 18,1986$. Union wins fifth and sixth elections.

Sept. 19, 1986. Workers arrive at a Mexico City shop and are met by 25 thugs in an effort to block election. They gain entrance and "19th of september" wins.

sept. 22 \& 23,1986 . Union wins two more elections.

Sept. 27, 1986. Registration of the union is upheld in court. Union demonstrates to demand a solidarity fund for garment workers from the National clothing Industry Chamber.

oct. 23-25, 1986. International Garment Workers' Exchange and solidarity Meeting takes place in Mexico City.

oct. 25, 1986. Confederation of Mexican Workers (CTM) beat up garment workers at a factory seeking "19th of september" representation; 200 fired from another factory for demanding compensation. 
Nov. 12 1986. CTM announces plans to form a national garment workers union.

Nov. 26, 1986. Union members march on International Day Against Violence Against Women. Union representatives speak against sexual harassment of garment workers and violence against union activists. Celebration of "Day of the Garment Worker."

Source: International Bulletin of the 19th of september Union, May 20, 1987. 